\title{
GILBERTO TONIM
}

\section{A GESTÃO DE ENERGIA ELÉTRICA NA INDÚSTRIA - SEU SUPRIMENTO E USO EFICIENTE}


GILBERTO TONIM

\title{
A GESTÃO DE ENERGIA ELÉTRICA NA INDÚSTRIA - SEU SUPRIMENTO E USO EFICIENTE
}

\author{
Dissertação apresentada à \\ Universidade de São Paulo para \\ obtenção do título de Mestre em \\ Engenharia
}

Área de Concentração: Sistemas de Potência

Orientador: Prof. Dr. Luiz Natal Rossi

\section{São Paulo}


Este exemplar foi revisado e alterado em relação à versão original, sob responsabilidade única do autor e com a anuência de seu orientador.

São Paulo, 13 de outubro de 2009.

Assinatura do autor

Assinatura do orientador

FICHA CATALOGRÁFICA

Tonim, Gilberto

A gestão de energia elétrica na indústria - seu suprimento e uso eficiente / G. Tonim. -- ed.rev. -- São Paulo, 2009.

$112 \mathrm{p}$.

Dissertação (Mestrado) - Escola Politécnica da Universidade de São Paulo. Departamento de Engenharia de Energia e Automação Elétricas.

1. Energia elétrica 2. Economia de energia 3. Indústrias I. Universidade de São Paulo. Escola Politécnica. Departamento de Engenharia de Energia e Automação Elétricas II. t. 
A minha esposa Ana Lúcia e filhos Rodrigo, Juliana e Bruno.

Aos meus pais Luiz e Adriana que sempre me ajudaram com suas palavras motivadoras ao longo da minha vida. 


\section{AGRADECIMENTOS}

A minha família que me apoiou, incentivou e me inspirou na concretização deste trabalho.

Ao meu orientador Prof. Dr. Luiz Natal Rossi que conduziu com maestria todo o processo de elaboração deste trabalho.

Ao Prof. Dr. Fernando Amaral de Almeida Prado pelo incentivo, pela ajuda e dedicação demonstrada durante a realização deste trabalho.

Ao Prof. Dr. Marco Antonio Saidel por ter podido compartilhar momentos de grande aprendizado durante o curso de pós-graduação. 
Existe o risco que você não pode jamais correr, e existe o risco que você não pode deixar de correr. 


\section{RESUMO}

O crescente valor pago pela fatura de energia elétrica sucedendo um período de indisponibilidade quando do racionamento em 2001, concomitantemente com as novas regulamentações do setor elétrico, fizeram com que algumas indústrias buscassem melhor entender o negócio "energia elétrica" de forma a se precaver de um possível novo racionamento. As indústrias foram em busca de preços mais atrativos, objetivando garantir seu processo produtivo com competitividade.

O setor elétrico buscou estimular o investimento privado e o crescimento sustentável do mercado de energia elétrica no Brasil, e também incentivar o usuário final a melhor fazer a gestão dos gastos e consumos de energia elétrica através de novas regulamentações, incentivos à eficiência energética, acelerando a competitividade nos preços de energia elétrica, entre outras ações.

Este trabalho apresenta um resumo dos fatos relevantes que ocorreram no setor elétrico brasileiro e cita os principais impactos ocorridos na indústria, a transformação do consumidor em cliente, ou seja, de mero pagador de fatura ao responsável pela escolha do fornecedor e o atual gestor do gasto e do consumo de energia em sua indústria.

Esta dissertação propõe um modelo de gestão de energia elétrica baseado em um caso de sucesso ocorrido numa grande indústria de alimentos do Brasil, apresentando os resultados obtidos.

Palavras-chave: racionamento de energia, gestão de gasto com energia, eficiência energética, competitividade. 


\begin{abstract}
The increasing amount paid for the electricity energy invoice after the period of unavailability on the occasion of the energy rationing in 2001, concurrently with the new regulations of the energy sector, have made some industries pursue a better understanding of the energy business in order to avoid a possible new energy rationing. The companies have also been searching for more attractive prices, aiming at ensuring competitiveness in their production process.

The electrical energy sector has sought to stimulate private investment and sustainable growth of the energy market in Brazil, apart from providing incentive for the end user in terms of improving their expenditures and energy consumption management through new regulations and incentives for energy efficiency, accelerating the competitiveness of energy price, among other actions.

The contents of this dissertation present a summary of relevant facts that occurred in the Brazilian electricity sector. Moreover, they cite the major impacts on the industry, the transformation of consumers into customers, i.e. from a mere bill payer to a customer who is responsible for choosing the energy provider, also becoming the current expenditure and energy consumption manager of their own company.

This dissertation proposes a model of energy management based on a successful case occurred in a major food processing industry in Brazil, presenting the results.
\end{abstract}

Keywords: energy rationing, energy management, energy efficiency, competitiveness. 


\section{LISTA DE ILUSTRAÇÕES}

Figura 3.1 -Taxas Anuais de Remuneração do Setor Elétrico-1974/1987........ 18

Figura 4.1 - Usinas Integrantes do Programa Prioritário de termeletricidade.. 27

Figura 4.2 - Nível dos Reservatórios da Região Sudeste ............................ 28

Figura 4.3 - Localização e Potência das Usinas Hidrelétricas ...................... 32

Figura 4.4 - Crescimento da Migração de Consumidores para o ACL .......... 39

Figura 4.5 - Evolução dos Consumidores Livres .................................... 40

Figura 4.6 - Comercialização de Energia Elétrica .................................... 42

Figura 5.1 - Estrutura tarifária Convencional ....................................... 46

Figura 5.2 - Curva de Carga no SIN.............................................. 47

Figura 5.3 - Efeito Tarifas Horo Sazonal(THS).................................... 48

Figura 5.4 - Tarifa Horo-sazonal Azul................................................. 49

Figura 5.5 - Tarifa Horo-sazonal Verde .......................................... 50

Figura 5.6 - Evolução dos Encargos Setoriais ..................................... 52

Figura 5.7 - Evolução das tarifas - Segmento Industrial ........................... 55

Figura 6.1 - Exemplo de Gerenciamento da Demanda .............................. 61

Figura 6.2 - Exemplo de Não Gerenciamento da Demanda .........................62 62

Figura 6.3 - Comparativo de Indicadores Econômicos no Brasil .................... 68

Figura 6.4 - Evolução das Tarifas em Percentual - Cemig THS Azul .......... 68

Figura 6.5 - Evolução das Tarifas em Percentual - Light THS Azul .............. 69

Figura 6.6 - Unidade A x ML - IGPM + 2\% ...................................... 81

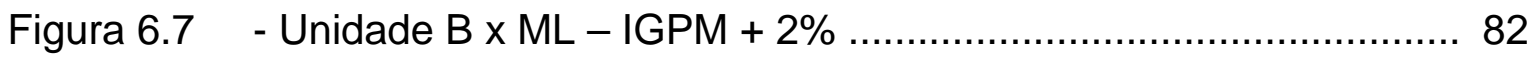

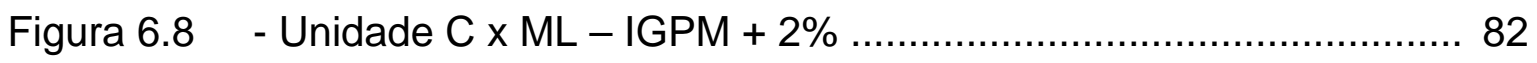

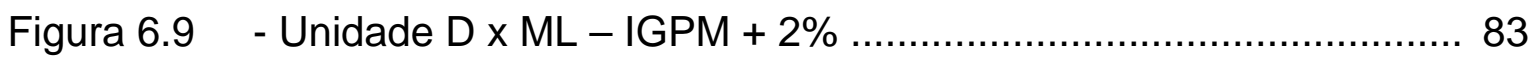

Figura 6.10 - Unidade Ex ML - IGPM + 2\% ......................................... 84

Figura 6.11 - Sazonalidade, Flexibilização e Modulação de Carga ................. 85

Figura 6.12 - Evolução dos Consumos Setorias de Energia Elétrica ............... 89

Figura 6.13 - Situação Encontrada no Parque de Ar Comprimido.................... 91 
Figura 6.14 - Instalação do Sistema Ideal de Ar Comprimido......................... 92

Figura 6.15 - Registros de Corrente e Potência Compressores ZR...................94 94

Figura 6.16 - Registros de Corrente e Potência Compressor SIERRA............ 94

Figura 6.17 - Registros de Corrente e Potência Compressor NIRVANA.............95

Figura 6.18 - Gerenciamento de Energia na Indústria Estudada .................... 100 


\section{LISTA DE TABELAS}

Tabela 4.1 - Acréscimo na Capacidade de geração entre 1995 a 1989............ 26

Tabela 4.2 - Redução no Consumo por Segmento ........................................ 29

Tabela 4.3 - Potência Instalada e Ampliação Prevista para 2004 ...................... 30

Tabela 4.4 - Ampliação da Oferta de Energia Elétrica 2001 - 2004 ................ 31

Tabela 4.5 - Ampliação da Oferta de Energia Elétrica - 1974 - 2007 .............. 33

Tabela 4.6 - Evolução da Operação dos Agentes Consumidores Livres na

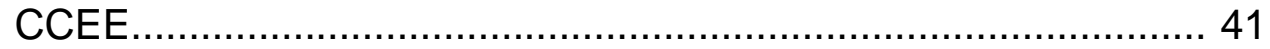

Tabela 5.1 - Composição da Receita Requerida ….....................................51

Tabela 5.2 - Participação dos Itens da parcela A e B na Receita Requerida das Sete Maiores Distribuidoras ............................................. 52

Tabela 5.3 - Variação Anual das tarifas Médias de Energia Elétrica (\%) ......... 54

Tabela 5.4 - Valor Médio das tarifas de Energia Elétrica (R $\$ / M W h)$.................54

Tabela 6.1 - Informações referentes à Demanda de Energia na Indústria Estudada ................................................................... 72

Tabela 6.2 - Informações referentes ao Consumo de Energia na Indústria

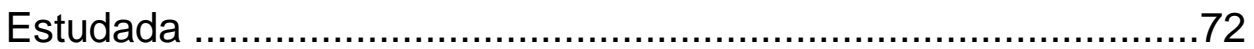

Tabela 6.3 - Tarifas nas Modalidades THS Azul e Verde - CPFL Paulista....... 76

Tabela 6.4 - Valores Levantados no Diagnóstico Energético.......................... 97

Tabela 6.5 - Cálculo das Economias Obtidas na Indústria Estudada .............. 98

Tabela 6.6 - Economias Previstas e Obtidas na Indústria Estudada................ 99 


\section{LISTA DE ABREVIATURAS E SIGLAS}
ACL - Ambiente de Comercialização Livre
ACR - Ambiente de comercialização Regulado
AGU - Advocacia Geral da União
AMFORP - American and Foreign Power Company
ANEEL - Agência Nacional de Energia Elétrica
BNDES - Banco Nacional de Desenvolvimento
BOT - Built Operation and Transfer
CBEE - Comercializadora Brasileira de Energia Emergencial
CCC - Conta de Consumo de Combustível
CCEE - Câmara de Comercialização de Energia Elétrica
CCON - Comitê Coordenador da Operação Norte-Nordeste
CCPE - Comitê Coordenador do Planejamento da Expansão
CDE - Conta de Desenvolvimento Energético
CEEE - Companhia Estadual de Energia Elétrica
CEMIG - Centrais Elétricas de Minas Gerais
CESP - Companhia Energética de São Paulo
CHESF - Companhia Hidroelétrica do São Francisco
CICE - Comissão interna de Conservação de Energia
CME - Custo Marginal de Expansão
CMO - Custo Marginal de Operação
CMSE - Comitê de Monitoramento do Setor Elétrico
CNAEE - Conselho Nacional de Águas e Energia Elétrica
CNPE - Conselho Nacional de Política Energética
COPEL - Companhia Paranaense de Energia
CPFL - Companhia Paulista de Força e Luz
CRC - Conta de Resultado a Compensar
CVA - Conta de Compensação de Variação de Valores de itens da parcela A 


\begin{tabular}{|c|c|}
\hline DNAE & - Departamento Nacional de Águas e Energia \\
\hline DNAEE & - Departamento Nacional de Águas e Energia Elétrica \\
\hline DNPM & - Departamento Nacional de Produção Mineral \\
\hline EPE & - Empresa de Pesquisa Energética \\
\hline FC & - Fator de Carga \\
\hline FFE & - Fundo Federal de Eletrificação \\
\hline FP & - Fator de Potência \\
\hline GCE & - Câmara de Gestão da Crise de Energia Elétrica \\
\hline GCOI & - Grupo Coordenador para Operação Interligada \\
\hline GCPS & - Grupo Coordenador do Planejamento do Sistemas Elétricos \\
\hline IGP-M & - índice Geral de Preços - Mercado \\
\hline IPC & - Índice de Preço ao Consumidor \\
\hline IPCA & - Índice de Preço ao Consumidor Amplo \\
\hline IUEE & - Imposto Único sobre Energia Elétrica \\
\hline MAE & - Mercado Atacadista de Energia \\
\hline MME & - Ministério de Minas e Energia \\
\hline ONS & - Operador Nacional do Sistema \\
\hline $\mathrm{PCH}$ & - Pequenas Centrais Hidrelétricas \\
\hline PDE & - Plano Decenal da Expansão dos Sistemas Elétricos \\
\hline PDET & - Programa Determinativo da Expansão da Transmissão \\
\hline PIE & - Produtor Independente de Energia \\
\hline PLD & - Preço de Liquidação de Diferenças \\
\hline PND & - Plano Nacional de Desenvolvimento \\
\hline PROCEL & - Programa Nacional de Conservação de Energia Elétrica \\
\hline PROINFA & - Plano de Incentivo às Fontes Alternativas de Energia Elétrica \\
\hline PRS & - Plano de Recuperação Setorial \\
\hline PURE & - Programa Para o Uso Eficiente de Energia \\
\hline RGE & - Rio Grande Energia \\
\hline RGG & - Reserva Global de Garantia \\
\hline RGR & - Reserva Global de Reversão \\
\hline RTE & - Revisão Tarifária Extraordinária \\
\hline SIN & - Sistema Interligado Nacional \\
\hline SINTREL & - Sistema Nacional de Transmissão de Energia Elétrica \\
\hline SNIS & - Sistema Nacional de Informações sobre Saneamento \\
\hline
\end{tabular}


TEP - Tonelada Equivalente de Petróleo

TUSD - Tarifa de Uso do Sistema de Distribuição

TUST - Tarifa de Uso do Sistema de Transmissão

UC - Unidade Consumidora

VPL - Valor Presente Líquido 
SUMÁRIO

\section{CAPÍTULO 1}

INTRODUÇÃO.

1.1. Contextualização 01

1.2. Estrutura do Trabalho 04

\section{CAPÍTULO 2}

REVISÃO DA LITERATURA 05

\section{CAPÍTULO 3}

FATOS RELEVANTES DO DESENVOLVIMENTO DO SETOR ELÉTRICO NACIONAL ATÉ A PROMULGAÇÃO DAS LEIS 8987/95 E 9074/95

CAPÍTULO 4

O MODELO INSTITUCIONAL DO SETOR ELÉTICO ADOTADO EM 1997 E OS DESDOBRAMENTOS DA CRISE DE ABASTECIMENTO DE ENERGIA EM 2001............................... 24

4.1. Revitalização do Modelo Elétrico 32 
TARIFAS E REVISÃO TARIFÁRIA - COMPONENTES E FORMA DE APLICAÇÃO.

\section{CAPITULO 6}

\section{A GESTÃO DE ENERGIA ELÉTRICA NA INDÚSTRIA - SEU} SUPERIMENTO E USO EFICIENTE.

6.1 A instalação e/ou ampliação de uma planta industrial e a contratação de energia elétrica 65

6.2 A Gestão dos gastos com energia elétrica na indústria. 71

6.3 A Eficiência Energética na Indústria de Alta e Média Tensão 87

6.4 Resultados obtidos em 2005 através das ações de Eficiência Energética e redução de gastos ( $\mathrm{R} \$ / \mathrm{kWh})$. 100

\section{CAPITULO 7}

CONSIDERAÇÕES FINAIS 102 


\section{CAPÍTULO 1}

\section{INTRODUÇÃO}

O objetivo do presente trabalho é apresentar os resultados obtidos com ações voltadas para a gestão dos gastos com energia elétrica, contemplando: a melhor opção tarifária; a forma de contratação da energia; a adoção de medidas visando à eficiência energética, implementadas em uma indústria de alimento composta de cinqüenta e quatro unidades consumidoras, tendo o seu suprimento de energia efetuado em média e alta tensão.

A motivação maior para a realização deste trabalho veio com o expressivo resultado obtido em redução de gastos com as faturas de energia elétrica, com a aplicação de um modelo de gestão e de ações de eficiência energética implantadas no processo produtivo.

\subsection{Contextualização}

Entre 1985 a 1990 dois programas voltados para a eficiência energética foram instituídos no Brasil. O Procel - Programa de Conservação de Energia Elétrica (1985), e o Conpet - Programa de Racionalização do Uso de Derivados de Petróleo e Gás Natural (1990). Em 1991 foram criadas a CICE - Comissão 
Interna de Conservação de Energia em todo órgão ou entidade da Administração Federal, fundações, empresas públicas e sociedades de economia mista controladas direta ou indiretamente pela União, que apresentasse consumo anual de energia elétrica superior a $600.000 \mathrm{kWh}$, ou consumo anual de combustível superior a 15 TEPs (BRASIL, 1990)

Estas iniciativas, porém, não foram suficientes para sensibilizar os diversos setores da economia e os consumidores sobre a necessidade de utilização racional da energia. Entretanto, a partir de 2001, em decorrência da crise de abastecimento de eletricidade, ficou demonstrada a fundamental importância da adoção de ações objetivando melhorias nos usos finais de energia.

As indústrias sentiram fortemente a restrição no fornecimento de eletricidade, havendo decréscimo da atividade produtiva.

Terminado o racionamento em 2002 as indústrias se depararam com dois novos fatores: a RTE - Revisão Tarifária Extraordinária, instituída pela Lei. 10.438 de $2002^{1}$, e com o realinhamento tarifário instituído pelo Decreto $\mathrm{n}^{\circ}$ 4.562, de 31 de dezembro de 2002, alterado pelo Decreto $n^{\circ} 4.667$, de 4 de abril de 2003.

O projeto de realinhamento tarifário objetivou eliminar gradualmente os subsídios cruzados, ou seja, custos diferenciados da energia que existiam nas tarifas dos consumidores enquadrados nas classes de baixa tensão em relação aos consumidores atendidos em alta tensão, de modo que até 2007 todos os consumidores passassem a pagar o mesmo valor pela energia adquirida e valores diferenciados pelos encargos de uso dos sistemas de transmissão e distribuição. Assim, a partir de 2003, os consumidores atendidos em alta tensão passaram a ter reajustes maiores em suas tarifas de fornecimento, excetuando-se deste processo apenas as cooperativas.

Com a elevação das tarifas de fornecimento as indústrias começaram a perceber que, além da necessidade de adoção de medidas de eficiência energética, era necessário aprimorar o gerenciamento das faturas de energia, analisando vários parâmetros elétricos, ou seja: Consumo Ativo (kWh),

\footnotetext{
${ }^{1}$ A Revisão Tarifária Extraordinária é discutida no Capítulo 5.
} 
Demanda (kW), Fator de Carga (FC), Fator de Potência (FP), Consumo Específico e Preço Médio. Conhecendo-se estes parâmetros elétricos, definese a melhor forma de contratação de energia nas diferentes modalidades tarifárias.

As indústrias passaram a avaliar, também, qual a melhor opção de contratação de energia, uma vez que a abertura tarifária possibilitou ao consumidor conhecer o valor de cada parcela que compõe a sua conta de energia, explicitando-se o valor pago pela energia elétrica consumida (tarifa de energia), o valor pago pelo uso do sistema de distribuição e transmissão, bem como todos os elementos de custo que compõem estas tarifas, que constam nas notas técnicas de revisões tarifárias publicadas pela Aneel. Este mecanismo permite que os consumidores cativos atualmente atendidos por uma concessionária de serviço público de distribuição, considerando as regras estabelecidas na legislação em vigor, possam avaliar a oportunidade de se tornarem consumidores livres, comparando os valores das tarifas cobradas pela sua atual concessionária de distribuição e optar pela compra da energia elétrica de outro agente vendedor.

A possibilidade de escolha do ambiente no qual se realizará a compra de energia elétrica pelos consumidores potencialmente livres foi estabelecida na Lei $10.848 / 2004$, regulamentada pelo Decreto $n^{\circ} 5.163$, que dentre outras medidas instituiu os Ambientes de Contratação Livre - ACL, onde os contratos são livremente negociados entre os agentes vendedores e os comercializadores ou consumidores livres, e o Ambiente de Contratação Regulado - ACR - no qual são firmados contratos regulados entre os agentes vendedores e os agentes de distribuição de energia elétrica. 


\subsection{Estrutura do Trabalho}

Conforme Umberto $\mathrm{Eco}^{2}$ uma tese, por razões ocasionais, se dirige ao examinador, mas presume que possa ser lida e consultada, de fato, por muitos outros, mesmo estudiosos não versados diretamente naquela disciplina.

Com base nesta citação, foi composta a estrutura desta dissertação de modo a oferecer ao leitor, não conhecedor da área, um panorama sobre o setor elétrico para, ao final, apresentar o estudo específico.

Apresenta-se no capítulo 2 uma revisão da literatura voltada para os objetivos deste trabalho. A história do setor elétrico, sua regulação, modicidade tarifária, dentre outros assuntos, encontra-se em uma bibliografia ampla, detalhada por vários autores ${ }^{3}$. Assim, no Capítulo 3 são apresentados alguns fatos relevantes que marcaram a trajetória do setor elétrico, sem a pretensão de um relato minucioso. O modelo institucional do setor elétrico adotado em 1997 e os desdobramentos da crise de energia estão apresentados no capítulo 4, que é finalizado com a apresentação das instituições que passaram a compor o setor elétrico. A abordagem sobre tarifas e revisão tarifária está apresentada no capítulo 5, com destaque para o aumento das tarifas ocorrido a partir de 1999. No capítulo 6, aborda-se a gestão do consumo de energia elétrica na indústria e a implantação de ações voltadas para a eficiência energética, apresentandose dados referentes à implantação destas ações em uma indústria do ramo alimentício, onde trabalha o autor desta dissertação. Considerações finais para novos estudos estão apresentadas no capítulo 7.

\footnotetext{
${ }^{2}$ Livro "Como se faz uma Tese", ed. Perspectiva, São Paulo, 1995

${ }^{3}$ O Livro "Panorama do setor elétrico no Brasil", coordenado por Paulo B. de Barros Cachapuz, Rio de Janeiro, Centro de Memória da Eletricidade do Brasil, 2006, apresenta um completo histórico do setor elétrico no Brasil.
} 


\section{CAPÍTULO 2}

\section{REVISÃO DA LITERATURA}

Com a crise do petróleo no final da década de 70 e início dos anos 80 abre-se no Brasil o mercado para serviços de eficiência energética. Para Poole e Geller (1997) a ênfase inicial para a ação das empresas de eficiência energética estava voltada para a substituição de derivados de petróleo em detrimento de um melhor uso do combustível. Com a estabilização do preço do petróleo e a ausência de um cenário crítico quanto ao fornecimento de energia elétrica, o mercado para os serviços de eficiência energética desacelerou, voltando a ser impulsionado somente após a crise de abastecimento no fornecimento de energia elétrica verificada em 2001.

O uso da energia comercial e industrial no Brasil, seus preços e potenciais de conservação, especialmente na área de energia elétrica, e a atuação das empresas de serviço de energia são temas abordados pelos autores acima citados no estudo realizado sobre o novo mercado de serviços de eficiência energética no Brasil.

Um estudo de cenários no contexto energético, político e tecnológico e análise das ações de eficiência energética no âmbito industrial são apresentados por Sola e Kovaleski (2004), que avaliam os impactos das medidas governamentais voltadas para as ações de eficiência. Estes autores 
apresentam em seus trabalhos cenários que apontam para uma necessidade de crescimento econômico com uso racional de recursos naturais. Para este estudo foram feitas pesquisas junto a algumas indústrias da região de Ponta Grossa, Paraná, que revelaram dificuldades na substituição dos equipamentos e processos obsoletos. Os autores observaram maiores oportunidades de mercado nas atividades de projeto e desenvolvimento de produtos, sobretudo nos setores elétrico e eletrônico.

O impacto da Lei, número 10.295, de Eficiência Energética para motores elétricos no potencial de conservação de energia elétrica na indústria é apresentado por Garcia (2003). Este autor discute a lei de eficiência energética, os programas de etiquetagem e padronização, a regulamentação dos motores, o uso e o potencial de conservação de energia final na indústria, em especial a elétrica e em força motriz. Este autor apresenta em seu estudo cinco análises: quanto economizará a aplicação da Lei; quanto economizaria se os motores fossem trocados por unidades de alto rendimento; qual o potencial de economia se os motores fossem simplesmente adequados à carga que acionam; qual a viabilidade de se realizarem trocas imediatas por motores de alto rendimento e, finalmente, de certa forma englobando as outras, qual a redução obtida na troca, ao final da vida útil, por motores de alto rendimento adequados à carga. Da amostra, é feita também uma projeção para o conjunto da indústria brasileira. As respostas indicam que o potencial de conservação de eletricidade em motores deve ser mais bem explorado.

Martins (1999) aborda a eficiência energética e seus desdobramentos nos diferentes segmentos da economia sob a ótica da inovação tecnológica. Esta autora apresenta o crescimento da demanda por energia elétrica frente à oferta de energia e o advento da eficiência energética no mercado como solução para atendimento desse crescimento da demanda. Aborda o uso e difusão de sistemas e redes de inovação, introduzindo os conceitos de novos paradigmas de inovação tecnológica e sua influência sobre a eficiência energética. Destaca no final do seu trabalho os desafios e principais obstáculos a serem transpostos no Brasil, tendo em vista a quebra dos paradigmas existentes quanto ao uso desordenado da energia elétrica. 
O autor ainda discute o conceito que a eficientização energética representa importante campo de inovação tecnológica, organizacional e institucional.

Uma análise do mecanismo regulatório colocado em prática no Brasil para fomentar investimentos em eficiência e pesquisa e desenvolvimento, pelas empresas privatizadas, com o objetivo de verificar se está sendo realmente eficaz para prover bens públicos para o país, é apresentada por Jannuzzi (2000) que aborda as experiências vivenciadas pelos Estados Unidos e Brasil.

Da mesma forma que as ações de eficiência energética tomaram vulto após o racionamento, ações voltadas para um melhor gerenciamento de energia elétrica passaram a ser adotadas pelos diversos segmentos consumidores.

Oliveira (2006) faz uma completa abordagem sobre a gestão da energia elétrica, analisando o consumo verificado no Campus da UnB. Aborda em seu trabalho, além dos índices de eficiência energética, outras características de sistemas elétricos de potência, como carga, demanda, potência, tensão, perdas, bem como executou uma avaliação sobre as opções tarifárias. Apresenta ainda sistemas de monitoração do consumo de energia e sua implantação na Universidade de Brasília.

A USP - Universidade de São Paulo também adotou um programa voltado para o uso eficiente de energia e gestão. Em 1997 a USP criou o Programa Para o Uso Eficiente de Energia - PURE, tendo o Prof. Dr. Marco Antonio Saidel como gestor geral do programa. Foram implantadas ações voltadas para a gestão das faturas, gestão de contratos e projetos de eficiência energética. Os resultados das ações estão disponíveis em diversas publicações, incluindo-se a internet.

O setor de saneamento também vem adotando medidas de eficiência energética e de gerenciamento do uso da energia, existindo incentivos através do PROCEL com o Programa Sanear. O item energia elétrica na composição dos gastos no sistema de saneamento aparece em segundo lugar, perdendo apenas para a folha de pagamento, conforme dados contidos no SNIS Sistema Nacional de Informações sobre Saneamento. 
Um estudo de gerenciamento da energia elétrica em uma empresa de saneamento ambiental é apresentado por Oliveira (2002). As ações de gestão de energia implantadas pela empresa Saneamento de Goiás S/A voltaram-se para atualização do cadastro das unidades consumidoras de energia elétrica; controle efetivo das faturas; correção do fator de potência elétrico; mudança do grupo tarifário e a adoção de um sistema computacional de gestão energética.

O gerenciamento com os gastos com energia elétrica passa também pela necessidade de se observar qual o melhor ambiente para a contratação de energia, o regulado - ACR ou o livre - ACL.

Um aprofundado estudo sobre os critérios de decisão na migração de consumidores para o ambiente de contratação livre é apresentado por Aguiar (2008). Em seu estudo apresenta uma análise para a tomada de decisão do consumidor potencialmente livre, incluindo estudo de caso com a aplicação do Valor Presente Líquido, a fim de determinar o preço dos contratos no Ambiente de Contratação Livre.

Aguiar (2008) apresenta as variáveis de cada mercado, livre e cativo, os pontos a serem observados e os riscos envolvidos quando da tomada de decisão pelo consumidor.

Uma discussão sobre o preço da energia elétrica é apresentada por Barbosa (2007) que aborda a influência do PLD - Preço de Liquidação das Diferenças no preço da contratação bilateral no Ambiente de Contratação Livre. Este autor destaca que tal referência de preço forma a base para todos os cálculos de alternativas de contratação de energia elétrica, análise de riscos, e ainda, para a análise da viabilidade econômica de empreendimentos. Assim, o preço da contratação bilateral no ACL é também influenciado pelo PLD.

Uma Metodologia para precificação e análise do risco de contratação entre submercados no setor elétrico brasileiro é apresentada por Porrua (2005). Este autor propôs uma metodologia para precificar o risco da contratação de energia elétrica entre submercados no sistema elétrico brasileiro, baseado em estimar o sobre preço que o gerador estaria a cobrar por um contrato bilateral, fora do seu submercado. 
Silva e Belderrain (2002) apresentam um estudo da relação entre gerenciamento de risco e análise de decisão demonstrando a relação entre a metodologia de Análise de Decisão e os conceitos de Gerenciamento de Risco, estudo importante que pode auxiliar na tomada de decisão para a migração ao ambiente de contratação livre.

A grande quantidade de trabalhos publicados sobre gestão de gastos com energia elétrica e uso eficiente, temas principais deste trabalho, demonstra a importância crescente que assumem nas estratégias de competitividade das empresas. 


\section{CAPÍTULO 3}

\section{FATOS RELEVANTES DO DESENVOLVIMENTO DO SETOR ELÉTRICO NACIONAL ATÉ A PROMULGAÇÃO DAS LEIS 8987/95 E 9074/95}

Foi na virada do século XIX que a exploração econômica da eletricidade surgiu no Brasil com a implantação de empreendimentos isolados e de controle privado, que atuavam através de licença concedida pelo município em que os serviços estavam sendo prestados (AMARAL FILHO, 2007).

O eixo Rio-São Paulo, onde se localizam os centros urbanos de maior porte e dinamismo econômico, atraiu para o Brasil uma empresa canadense que em 1899 constituiu a São Paulo Tramway Light and Power Co.; em 1904 a empresa Rio de Janeiro Tramway Light and Power Co.; e em 1910 a São Paulo Electric Company Ltda, sendo que em 1912 essas passaram a ser controladas pela holding constituída no Canadá The Brazilian Traction Light and Power Co. Ltd., que também controlava outros serviços públicos, sendo o mais importante o transporte em bonde (AMARAL FILHO, 2007).

Para o desenvolvimento dos serviços de eletricidade no interior de São Paulo e em outros centros urbanos de maior expressão no país, foi criada em 1923 a empresa AMFORP - American and Foreign Power Company que passou a 
monopolizar nessas regiões os sistemas de eletricidade, gás, linhas de bonde e também de telefonia (GREINER, 1994).

Essas duas empresas incorporaram outras concessionárias e atuaram sem muita interferência do Estado até 1934, sendo que os serviços de geração, transmissão e distribuição de energia foram organizados sob a forma de sistemas independentes e isolados (LEITE, 1997).

Em 1934 foi editado o Código de Águas através do Decreto 24.643, iniciando o processo de intervenção do Estado nos serviços de eletricidade. Este Código determinou que a tarifa para prestação do serviço se daria através do "serviço pelo custo" 4 em substituição à "cláusula ouro" 5 . As quedas d'águas foram incorporadas ao patrimônio da União e as concessões passaram a ser dadas a brasileiros ou empresas organizadas no país, resguardando-se os direitos até então adquiridos (BRASIL, 1934).

O Código de Águas foi regulamentado apenas em 1957, pelo Decreto 41.019, que estabeleceu as condições para a prestação dos serviços de energia elétrica, definindo: (i) a competência e diretrizes para a fiscalização técnica, contábil, financeira e inventários; (ii) as obrigações e direitos das empresas e dos consumidores; (iii) a participação dos consumidores nos investimentos; (iv) a permissão para aumentos tarifários, reservando ao Estado a faculdade de concedê-los; (v) a criação da cota de reversão, a remuneração do capital em 10\%, considerando o custo histórico corrigível nos termos da legislação vigente; e (vi) a criação da CRC - Conta de Resultados a Compensar, cujos saldos deveriam ser recolhidos 120 dias após o encerramento do exercício, sendo os negativos incluídos na remuneração do ano seguinte (GREINER, 1994).

Como o Estado não tinha recursos para explorar os serviços de eletricidade, o Código de Águas previu essa exploração por capitais privados,

\footnotetext{
${ }^{4}$ As tarifas são fixadas de modo a permitir ao prestador do serviço integral ressarcimento do custo incorrido para a prestação do serviço, incluídos no custo a depreciação, mais o lucro, ou remuneração do capital líquido, calculada à taxa de 10\%, arbitrada pelo Estado, Poder Concedente (AMARAL FILHO, 2007).

${ }^{5}$ Fixação de tarifas em moeda nacional, mas tendo o valor referenciado ao ouro, uma fórmula de amenizar os efeitos maléficos decorrentes da desvalorização da moeda nacional, representava uma garantia e proteção aos investidores (AMARAL FILHO, 2007).
} 
temporariamente, sendo que após o período de concessão os ativos de eletricidade seriam transferidos para o Estado (BRASIL, 1934).

Para viabilizar essa transferência de propriedade dos ativos foi criado o encargo Reserva de Reversão, incluído na tarifa e correspondente a 3\% do valor do capital aplicado, que ficava à disposição das empresas como fonte de recursos para financiamento (Fundo de Reversão). Esse Fundo de Reversão viabilizou a transferência da propriedade privada para o Estado depois de decorrido o prazo de concessão de 30 anos, pois ano após ano, o saldo devedor das empresas junto ao Fundo de Reversão era capitalizado com juros devidos, e acrescentado ao fluxo anual de recursos do encargo Reserva de Reversão (AMARAL FILHO, 2007).

Os serviços de eletricidade no decorrer da Segunda Guerra Mundial começaram a apresentar sinais de deterioração, levando à escassez do fornecimento. Segundo Leite (1997) esta situação decorreu dos seguintes fatores: (i) alteração do regime tarifário com a instituição do Código de Águas; (ii) longo período de dificuldades de importação e fraqueza do parque industrial nacional para suprir os equipamentos necessários à manutenção e expansão dos serviços; e (iii) inflação crônica, que no período de guerra resultou em aumento de preço da ordem de $100 \%$, correspondendo à média de $12 \%$ a.a.

Para dar seqüência ao desenvolvimento econômico iniciado na década de 30 , a partir dos anos 40 e ao longo dos anos 50 e 60 a formação do setor elétrico se desenvolveu dentro de uma mentalidade nacionalista. Foram criadas as empresas Estatais Federais CHESF - Companhia Hidrelétrica do São Francisco (1948) e Furnas - Centrais Elétricas S/A (1957). No âmbito estadual instalaram-se as empresas CEMIG - Centrais Elétricas de Minas Gerais (1952), CEEE - Companhia Estadual de Energia Elétrica (1943), COPEL Companhia Paranaense de Energia (1954), e a CESP - Companhia Energética de São Paulo ${ }^{6}$ (1966) (RAMALHO, 1999).

${ }^{6}$ A CESP foi criada a partir da junção das empresas Celusa - Centrais Elétricas de Urubupungá (1961), Cherp- Companhia Hidrelétrica do Rio Pardo (1955), Uselpa - Usinas Elétricas do Paranapanema (1953) e Belsa - Bandeirante de Eletricidade S/A (1962) 
A CESP passa a ter o controle acionário da CPFL - Companhia Paulista de Força e Luz em 1975, sendo que esta havia sido estatizada em 1964, quando a Eletrobrás adquiriu a AMFORP.

A estrutura do Setor Elétrico Brasileiro se consolida com a promulgação da Lei 3.890-A/61 que criou a ELETROBRÁS - Centrais Elétricas Brasileiras, cabendo a esta: (i) atuar como empresa holding de algumas empresas federais promotoras do desenvolvimento elétrico regional; (ii) gerir os fundos fiscais específicos, destinados à expansão da produção de energia elétrica; e (iii) coordenar o planejamento em nível nacional. (WAISMAN, 1980)

Com a criação em 1968 da ELETROSUL - Centrais Elétricas do Sul do Brasil S/A e da ELETRONORTE - Centrais Elétricas do Norte do Brasil em 1973, completa-se, juntamente com a CHESF e Furnas o grupo de empresas que teve a incumbência de planejar, construir e operar os sistemas de geração e transmissão das regiões norte, nordeste, sul, sudeste e centro-oeste, sob o controle da ELETROBRÁS (RAMALHO, 2003)

Para financiar o desenvolvimento do setor elétrico a partir da intervenção do Estado, foi criado em 1953 o Fundo Federal de Eletrificação - FFE, formado pela cobrança do Imposto Único sobre Energia Elétrica - IUEE e do empréstimo compulsório cobrado dos grandes consumidores. Do montante arrecadado do FFE, 40\% eram destinados à União, sendo que através do Banco Nacional de Desenvolvimento Econômico - BNDE, instituído em 1952, eram financiados os projetos mais urgentes. Os 60\% restantes do FFE eram destinados aos estados e municípios para serem aplicados na expansão de seus sistemas elétricos (ELETROBRAS, 1988).

$\mathrm{Na}$ ausência de mecanismos adequados de atualização das tarifas e com a aceleração da inflação nos anos 50 e início de 60, iniciou-se a deterioração da situação financeira das empresas do setor, que foi corrigida apenas em 1964 com a revisão tarifária, procurando-se adequá-las aos custos reais, a adoção da correção monetária dos ativos integrantes da base de remuneração e mecanismos de ajustamento periódico que, junto com a melhoria das fontes de financiamento setoriais e extra-setoriais, criaram condições favoráveis para o setor se desenvolver na década seguinte (RAMALHO, 2003) 
Em 1971 a taxa de remuneração, até então fixada em 10\%, foi revista para até $12 \%$ a.a (Lei 5.655, regulamentada pelo Decreto 69.721), permitindo que eventual excedente de remuneração fosse retido pela concessionária. A mesma Lei estabeleceu que o encargo denominado Reserva de Reversão, criado em 1957, passasse a ser recolhido à ordem da Eletrobrás, que se tornava a gestora dos recursos centralizados como Reserva Global de Reversão - RGR (BRASIL, 1971).

O Grupo Light, a maior concessionária privada do País, concretiza no final de 1978 negociações com o Governo Federal para venda de suas empresas, que são transferidas para a Eletrobrás, sendo que a parte pertencente a São Paulo posteriormente passaria para o Governo do Estado, criando a ELETROPAULO. Sob o controle privado só restaram as pequenas empresas que representavam 4\% das vendas de energia elétrica no País (AMARAL FILHO, 2007).

A Eletrobrás atuou de forma eficiente em termos técnico e econômico, pois havia sinalização clara de quanto cada usina iria gerar de energia, garantindo uma maior eficiência na disponibilização da água, de tal forma a otimizar a saída total de energia ao menor custo (FERREIRA, 2000).

Nos anos 70 ocorreu a expansão do sistema de geração através da construção das usinas hidrelétricas de Itaipu, Tucuruí, Ilha Solteira, e da Usina Nuclear de Angra dos Reis em 1975. Inicia-se a interligação de alguns sistemas de transmissão permitindo que a quantidade de energia produzida e distribuída acompanhasse o crescimento do mercado consumidor (RAMALHO, 2003)

O sistema centralizado de despacho através da otimização dos recursos hidráulicos passou a ser controlado pelo Grupo Coordenador para Operação Interligada - GCOI, instituído em 1973, substituindo o Sub-Comitê de Operação Interligada. O GCOI inicialmente coordenou a operação interligada, pioneira nacional, da hidrelétrica de Furnas para a região sudeste. (FERREIRA, 2000).

A projeção da demanda de energia elétrica do país ficou a cargo do GCPS Grupo Coordenador do Planejamento dos sistemas Elétricos, que passou a definir os investimentos necessários para a expansão das atividades de geração, transmissão e distribuição, estabelecendo o cronograma de projetos de investimentos para a priorização dos mais eficientes (FERREIRA, 2000). 
Os principais instrumentos de planejamento do GCPS foram os Planos, de Longo Prazo, revisado a cada cinco anos, e o Decenal de Expansão, revisado anualmente pelas empresas concessionárias, sob a coordenação da Eletrobrás. Esses planos eram definidos pelo lado da demanda, considerando os projetos de crescimento de mercados regionais, e pelo lado da oferta, em avaliações técnico-econômicas de empreendimentos capazes de atender a demanda prevista. (RAMALHO, 2003)

Quanto à política tarifária, até final da década de 50, esta ficou a cargo do Ministério da Agricultura. Com a criação do Ministério das Minas e Energia, instituído pela Lei 3.782, de julho de 1960, tal atividade Ihe foi atribuída, tendo como órgão subordinado o CNAEE - Conselho Nacional de Águas e Energia Elétrica, e o Departamento Nacional de Produção Mineral - DNPM, que englobava a Divisão de Águas (BRASIL, 1960).

Em 1965, através da Lei 4.904, foi instituído o DNAE - Departamento Nacional de Águas e Energia, que em 1968 passou a denominar-se Departamento Nacional de Águas e Energia Elétrica - DNAEE, com a promulgação do Decreto 63.951. Em 1969 o CNAEE foi extinto, ficando a cargo do DNAEE a incumbência de aplicar políticas e diretrizes para a exploração dos serviços de energia elétrica. (RAMALHO, 2003).

As tarifas de energia elétrica foram definidas pelo custo histórico de cada concessionária desde a publicação do Código de Águas até 1973, quando o Decreto-lei 1.383/74 introduziu a equalização tarifária em todo território nacional. Esta medida visava diminuir as desigualdades regionais, reduzindo as disparidades tarifárias decorrentes da maior concentração de consumidores e menor custo do serviço por consumidor nos mercados Sul-Sudeste. (AMARAL FILHO, 2007).

Esse regime tarifário deveria permitir a cobertura das despesas operacionais do setor e possibilitar uma remuneração às concessionárias variando de $10 \mathrm{a}$ $12 \%$, sendo que a rentabilidade passou a ser calculada pela média, ou seja, se resultasse em $6 \%$ a.a., as concessionárias que obtivessem resultado superior a essa média fariam a transferência do excedente para o novo encargo criado, denominado Reserva Global de Garantia - RGG. A diferença entre essa média 
e os 10\% mínimo assegurado foi contabilmente acumulada na CRC - Conta de Resultado a Compensar (AMARAL FILHO, 2007).

A fixação de tarifas ficou a cargo do DNAEE até 1977, passando-se esta incumbência, a partir deste ano, ao Ministério da Fazenda, através do Decreto 79.706. A partir de então as tarifas do setor elétrico deixam de refletir os custos dos serviços, passando a ser utilizadas como mecanismo de política econômica e de controle da inflação (MEDEIROS, 1996).

Em virtude da contenção dos reajustes tarifários para combater a aceleração da inflação, somados à desaceleração do crescimento da economia brasileira e à degradação da correção monetária usada para atualizar o valor dos ativos integrantes da base de cálculo da remuneração das empresas, o quadro favorável vivido pelo setor elétrico foi sendo alterado paulatinamente, concomitantemente com um período de forte investimento para atingir as metas do PND - Plano Nacional de Desenvolvimento (LESSA, 1998).

O investimento no setor passou a ser suportado por empréstimos e financiamentos no exterior, havendo uma forte centralização destes recursos em favor das empresas do Grupo Eletrobrás, e também por transferência de remuneração das empresas estaduais para as federais. Adiciona-se a este quadro a maxidesvalorização cambial de 30\% ocorrida em 1979, com o objetivo de estimular as exportações e gerar superávits comerciais para pagamento dos juros e atender ao serviço da dívida. Essa desvalorização teve grande impacto nas empresas endividadas em moeda estrangeira, dentre as quais despontavam as maiores empresas estatais do setor elétrico. Este quadro se agrava ainda mais com a elevação da taxa de juros pelo Federal Reserve Bank dos EUA, a partir de 1980, afetando o custo da dívida em moeda estrangeira contratada a taxas de juros flutuantes (AMARAL FILHO, 2007).

A taxa mínima de remuneração de $10 \%$ passou a não ser atingida e as insuficiências de remuneração foram registradas a crédito das empresas na Conta de Resultados a Compensar, cujo saldo integrava a base de cálculo da remuneração, juntamente com os investimentos realizados no ativo imobilizado, gerando um crescimento progressivo dos valores devidos, em paralelo a crise de recursos de caixa (AMARAL FILHO, 2007) 
Nova desvalorização cambial ocorreu em 1983, de 30\%, para uma inflação no patamar de 200\%, levando as concessionárias ao não recolhimento de encargos setoriais à Eletrobrás - RGR, fonte utilizada basicamente em favor das geradoras ligadas à Eletrobrás e Itaipu, e RGG, destinada a equalização das taxas de remuneração das empresas (RAMALHO, 2003)

Conforme Amaral Filho (2007), a RGR perdera sua razão de existir, pois visava a constituição de recursos para reversão ao Estado das empresas de propriedade privada, o que de fato já havia ocorrido. No caso da RGG, a justificativa era que seu recolhimento só teria sentido na parcela de remuneração excedente à taxa de remuneração mínima legal de 10\% a.a., há muito não obtida.

Diante da crise financeira o setor elétrico desenvolveu estudos que visavam apresentar propostas para o seu reequilíbrio. O primeiro, intitulado Plano de Recuperação Setorial - PRS, aprovado em 1985, preocupou-se com o saneamento do setor. Como diretrizes básicas, apontou a necessidade de reposição do nível tarifário, recuperação dos investimentos setoriais, obtenção de recursos internos e externos e estabelecimento de condições financeiras para a expansão acelerada da capacidade instalada (MEDEIROS, 1996).

Este plano não pode ser aplicado uma vez que o governo estabeleceu em 1986 o congelamento de preços e as tarifas não puderam ser reajustadas. A Figura 3.1 demonstra a taxa de remuneração do setor durante os anos de 1974 a 1987. 


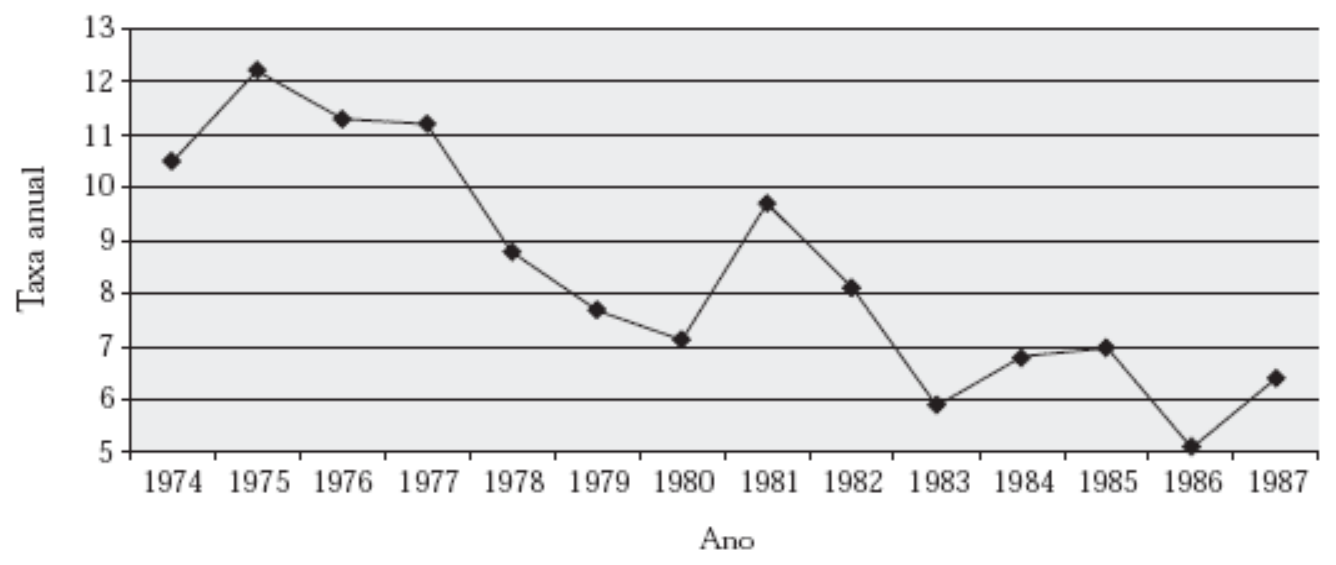

Figura 3.1 - Taxas Anuais de Remuneração do Setor Elétrico 74/87 Fonte: Goldenberg e Prado, 2003.

O segundo estudo realizado em 1988 denominado Revise - Revisão Institucional do Setor Elétrico apresentou alternativas para enfrentamento da crise, agrupadas em cinco áreas: (i) missão e papel do setor; (ii) aspectos institucionais; (iii) modelo econômico-financeiro; (iv) modelo organizacional; e (v) processo decisório (ELETROBRAS, 1988). Este estudo foi o primeiro a sinalizar a necessidade de inserção de capital privado no setor.

Com a publicação da Lei 8.031/90 foi criado o Programa Nacional de Desestatização - PND, o Governo sinalizou em 1992 a sua intenção em privatizar as empresas do Grupo Eletrobrás. Neste ano a situação financeira do setor tornou-se mais grave, pois se instalou uma inadimplência generalizada, tanto no recolhimento dos encargos setoriais quanto com os extra-setoriais pagamento do serviço da dívida externa (RAMALHO, 2003)

A Lei 8.631/93 figura como uma das primeiras medidas legais para a reestruturação do setor elétrico. As principais medidas desta lei foram: (i) utilização da CRC, da CCC e da Rencor ${ }^{7}$ na compensação dos débitos intrasetoriais e extra-setoriais para liquidação das dívidas pendentes; (ii) extinguiu o regime de remuneração garantida; (iii) substituiu a fixação das tarifas com base no regime de serviço pelo custo pela tarifa pelo preço; (iv) estabeleceu o fim da equalização tarifária em nível nacional, e as tarifas voltaram a ser fixadas, pelo

${ }^{7} \mathrm{CCC}$ - Conta de Consumo de Combustível

Rencor - Reserva Nacional de Compensação da Remuneração, instituída pelo Decreto Lei 2.432/88, que veio a substituir a RGG. 
DNAEE, individualmente para cada concessionária nas diferentes regiões do País; (v) a celebração de contratos de suprimento de energia, entre concessionárias e supridoras, documento indispensável para a aprovação das tarifas de fornecimento de propostas pelas distribuidoras; (vi) em caso de inadimplência junto às supridoras, as receitas das distribuidoras servirão como garantia de pagamento, através de autorização de débito automático nas respectivas contas bancárias; (vii) a reinstituição do recolhimento da RGR à Eletrobrás, em parcelas mensais, num total anual de 3\% dos investimentos imobilizados das concessionárias, sendo que as cotas anuais de cada empresa seriam fixadas pelo DNAEE, cabendo a este $2 \%$ destes recursos para custeio de suas atividades; e (viii) a inadimplência das concessionárias com as contribuições devidas à RGR e CCC, implicaria na impossibilidade de revisão e reajustes de suas tarifas (GREINER, 1994).

Para tentar minimizar o problema das obras não iniciadas ou paralisadas decorrente da insuficiência de recursos verificada na década de 80 , passou-se a permitir a formação de consórcios de empresas para a exploração dos aproveitamentos hidráulicos entre concessionárias e autoprodutores ${ }^{8}$, através do decreto 915/93, sendo esta iniciativa a primeira a introduzir capital privado na expansão do setor (BRASIL, 1993).

Com o Decreto 1.009 de dezembro de 1993, criou-se o SINTREL - Sistema Nacional de Transmissão de Energia Elétrica, a ser administrado pela Eletrobrás, que objetivava abrir as linhas de transmissão para o livre acesso de quaisquer geradores (BRASIL, 1993a). Porém, de acordo com Amaral Filho (2007), este encontrou resistência das grandes geradoras estaduais (CEMIG, CESP e COPEL) detentoras de parte importante e essencial da rede de transmissão.

A reestruturação do setor elétrico com a entrada de novos agentes para a exploração dos serviços de energia elétrica só ocorreu em 1995 com a promulgação das Leis 8.987 e 9.074, que vieram a regulamentar o artigo 175

\footnotetext{
${ }^{8}$ Autoprodutor de Energia Elétrica, a pessoa física ou jurídica ou empresas reunidas em consórcio que recebam concessão ou autorização para produzir energia elétrica destinada ao seu uso exclusivo (BRASIL, 2003)
} 
da Constituição Federal de $1988^{9}$. A Lei $8.987 / 95$ dispôs sobre o regime de concessão e permissão e a 9.074/95 tratou de normas para outorga e prorrogação das concessões e permissões.

A Lei 8987/95 tratou de forma geral das concessões, conceituando serviço adequado, direitos e obrigações dos usuários, licitação para obtenção das concessões, critérios de menor preço para a prestação dos serviços ou maior pagamento pela concessão, encargos do poder concedente, encargos da concessionária, da extinção da concessão, do regime das permissões, da política tarifária (BRASIL, 1995).

Já a Lei 9074/95 definiu o contorno da reforma do setor elétrico: licitação de novos potenciais hídricos visando proporcionar competição na geração; livre acesso à rede de transmissão e definição de uma malha básica, divisão dos consumidores entre livres e cativos, regulação por tetos tarifários, introdução do Produtor Independente de Energia - PIE ${ }^{10}$, obrigatoriedade de conclusão de projetos paralisados ou novas licitações dessas concessões; e mecanismos facilitadores para a privatização (RAMALHO, 2003).

Iniciou-se naquele ano o processo de privatização das distribuidoras concluído em 2000. Entre 1995 a 2000 foram privatizadas vinte e três concessionárias de distribuição.

Os novos agentes que passaram a compor o novo modelo de funcionamento do setor elétrico estão caracterizados abaixo (BRASIL, 1975a):

\section{> Produtor Independente de energia:}

Art. 11 e parágrafo único: pessoa jurídica ou empresas reunidas em consórcio que recebam concessão ou autorização do poder concedente, para produzir energia elétrica destinada ao comércio de toda ou parte da energia produzida, por sua conta e risco. O produtor independente de energia elétrica estará sujeito às regras de comercialização regulada ou livre, atendido ao disposto nesta Lei, na

\footnotetext{
${ }^{9}$ Art. 175 - Incumbe ao Poder Público, na forma da Lei, diretamente ou sob regime de concessão ou permissão, sempre através de licitação, a prestação de serviços públicos (BRASIL, 1988)

${ }^{10}$ PIE - regulamentado pelo Decreto 2003 de setembro de 1996
} 
legislação em vigor e no contrato de concessão ou no ato de autorização. (Redação dada pela Lei no 9.848 de 2004).

\section{Consumidor Livre:}

Art. 15. Respeitados os contratos de fornecimento vigentes, a prorrogação das atuais e as novas concessões serão feitas sem exclusividade de fornecimento de energia elétrica a consumidores com carga igual ou maior que $10.000 \mathrm{~kW}$, atendidos em tensão igual ou superior a $69 \mathrm{kV}$, que podem optar por contratar seu fornecimento, no todo ou em parte, com produtor independente de energia elétrica.

§ 10 Decorridos três anos da publicação desta Lei os consumidores referidos neste artigo poderão estender sua opção de compra a qualquer concessionário, permissionário ou autorizado de energia elétrica do sistema interligado. (Redação dada pela Lei no 9.648, de 1998)

\& 20 Decorridos cinco anos da publicação desta Lei, os consumidores com carga igual ou superior a $3.000 \mathrm{~kW}$, atendidos em tensão igual ou superior a $69 \mathrm{kV}$, poderão optar pela compra de energia elétrica a qualquer concessionário, permissionário ou autorizado de energia elétrica do mesmo sistema interligado.

§ 30 Após oito anos da publicação desta Lei, o poder concedente poderá diminuir os limites de carga e tensão estabelecidos neste e no art. 16.

§ 40 Os consumidores que não tiverem cláusulas de tempo determinado em seus contratos de fornecimento só poderão exercer a opção de que trata este artigo de acordo com prazos, formas e condições fixados em regulamentação específica, sendo que nenhum prazo poderá exceder a 36 (trinta e seis) meses, contado a partir da data de manifestação formal à concessionária, à permissionária ou à autorizada de distribuição que os atenda. (Redação dada pela Lei no 10.848 , de 2004)

§ 50 O exercício da opção pelo consumidor não poderá resultar em aumento tarifário para os consumidores remanescentes da concessionária de serviços públicos de energia elétrica que haja perdido mercado. (Redação dada pela Lei no 9.648 , de 1998)

§ 60 É assegurado aos fornecedores e respectivos consumidores livre acesso aos sistemas de distribuição e transmissão de 
concessionário e permissionário de serviço público, mediante ressarcimento do custo de transporte envolvido, calculado com base em critérios fixados pelo poder concedente.

\& 70 O consumidor que exercer a opção prevista neste artigo e no art. 16 desta Lei deverá garantir o atendimento à totalidade de sua carga, mediante contratação, com um ou mais fornecedores, sujeito a penalidade pelo descumprimento dessa obrigação, observado o disposto no art. $3^{\circ}$, inciso $X$, da Lei $n^{\circ}$ 9427, de 26 de dezembro de 1996. (Redação dada pela Lei no 10.848, de 2004)

§ 80 Os consumidores que exercerem a opção prevista neste artigo e no art. 16 desta Lei poderão retornar à condição de consumidor atendido mediante tarifa regulada, garantida a continuidade da prestação dos serviços, nos termos da lei e da regulamentação, desde que informem à concessionária, à permissionária ou à autorizada de distribuição local, com antecedência mínima de 5 (cinco) anos. (Incluído pela Lei $\mathrm{n}^{\circ} 10.848$, de 2004)

$\S 90$ Os prazos definidos nos §§ 40 e 80 deste artigo poderão ser reduzidos, a critério da concessionária, da permissionária ou da autorizada de distribuição local. (Incluído pela Lei $n^{\circ} 10.848$, de 2004)

$\S$ 10. Até 31 de dezembro de 2009, respeitados os contratos vigentes, será facultada aos consumidores que pretendam utilizar, em suas unidades industriais, energia elétrica produzida por geração própria, em regime de autoprodução ou produção independente, a redução da demanda e da energia contratadas ou a substituição dos contratos de fornecimento por contratos de uso dos sistemas elétricos, mediante notificação à concessionária de distribuição ou geração, com antecedência mínima de 180 (cento e oitenta) dias. (Incluído pela Lei no 10.848 de 2004)

Art. 16. É de livre escolha dos novos consumidores, cuja carga seja igual ou maior que $3.000 \mathrm{~kW}$, atendidos em qualquer tensão, o fornecedor com quem contratará sua compra de energia elétrica ${ }^{11}$.

Após o estabelecimento, por lei, das bases para a reestruturação do setor elétrico, iniciou-se a discussão sobre a sua reformulação na Secretaria de

${ }^{11}$ Em 20 de outubro de 2004 , através do decreto $n^{\circ} 5.249$, foi dada uma nova definição ao consumidor potencialmente livre "é aquele que, a despeito de cumprir as disposições estabelecidas no art. 15 da Lei 9.074 de 1995, é atendido de forma regulada". 
Energia do Ministério de Minas e Energia. Com este objetivo, reformular o setor elétrico, em 1996 foram contratados os serviços de consultoria do consórcio liderado pela empresa inglesa Coopers \& Lybrand, que propôs entre 1996 a 1998 medidas necessárias para o processo de reestruturação, tema tratado no próximo capítulo. 


\section{CAPÍTULO 4}

\section{O MODELO INSTITUCIONAL DO SETOR ELÉTICO ADOTADO EM 1997 E OS DESDOBRAMENTOS DA CRISE DE ABASTECIMENTO DE ENERGIA EM 2001}

Em 1996, com o objetivo de projetar um novo modelo para o setor elétrico brasileiro, o Ministério de Minas e Energia e a Eletrobrás selecionaram um consórcio para realizar estudo abrangente sobre a reforma do setor elétrico.

Em 1997 vieram as principais recomendações para a reestruturação pretendida: (i) criação de um mercado atacadista de energia - MAE; (ii) estabelecimento de contratos iniciais de compra de energia para criar uma fase de transição para o mercado competitivo; (iii) desmembramento dos ativos da transmissão e a criação de um Operador Nacional do Sistema - ONS para administrar o sistema interligado; e (iv) a organização das atividades financeiras e de planejamento da expansão. Este modelo sofreu importantes revisões após o racionamento de energia elétrica em 2001 (RAMALHO, 1999)

Em dezembro de 1996, através da Lei no 9427, foi criada a Agência Nacional de Energia Elétrica - Aneel, instituída como autarquia especial, vinculada ao Ministério de Minas e Energia, tendo como atribuição:

Art. $1^{\circ}$ A Agência Nacional de Energia Elétrica - ANEEL tem por finalidade regular e fiscalizar a produção, transmissão, distribuição e 
comercialização de energia elétrica, em conformidade com as políticas e diretrizes do governo federal (BRASIL, 1996).

Esta Lei ampliou o espectro de opções para que os consumidores pudessem tornar-se livres. Permitiu aos consumidores, cuja carga seja maior ou igual a $500 \mathrm{~kW}$, comprar energia de PCH - Pequenas Centrais Hidrelétricas ${ }^{12}$, usinas de biomassa, eólica ou solar, celebrando contrato de compra e venda de energia diretamente com a usina.

A recomendação de se criar um operador independente para administrar o sistema interligado foi atendida com a criação da ONS - Operador Nacional do Sistema Elétrico, em 1998, regulamentado pelo Decreto 2.655. É uma entidade de direito privado, sem fins lucrativos, responsável pela coordenação e controle da operação das instalações de geração e transmissão de energia elétrica no Sistema Interligado Nacional (SIN), sob a fiscalização e regulação da Agência Nacional de Energia Elétrica (BRASIL, 1998). O ONS passou a assumir as funções até então exercida pelo GCOI - Grupo Coordenador da Operação Interligada Sul/Sudeste e Centro Oeste e pelo CCON - Comitê Coordenador da Operação Norte-Nordeste.

O Mercado Atacadista de Energia, regulamentado pelo mesmo decreto, foi concebido como sendo um ambiente onde deveriam se realizar as transações de compra e venda de energia no sistema interligado, incluindo-se as atividades de contabilização destas transações e a liquidação das diferenças entre os valores contratados e os verificados por medição.

Neste modelo o planejamento da expansão ficou a cargo do Comitê Coordenador do Planejamento da Expansão - CCPE, criado em 1999 pelas Portarias do Ministério de Minas e Energia nos. 150 e 485, tendo como principal atribuição orientar as ações do governo para assegurar o fornecimento de

\footnotetext{
${ }^{12} \mathrm{O}$ conceito de $\mathrm{PCH}$, pela Lei 9.648/2008 foi ampliado para $30 \mathrm{MW}$ com exigência de definição com características específicas. Foi editada a Resolução pela Aneel, no 394/98, definindo como características de $\mathrm{PCH}$ : Potência instalada de até $30.000 \mathrm{~kW}$; área inundada máxima do reservatório de $30.000 \mathrm{~km}^{2}$, obtendo os incentivos: desconto de no mínimo 50\% nas tarifas de uso dos Sistemas de Transmissão e Distribuição, isenção de ônus pela utilização de Recursos da União e do pagamento da compensação financeira por área inundada, comercialização da energia para consumidores com carga igual ou superior a $500 \mathrm{~kW}$, em qualquer nível de tensão, direito de usufruto dos recursos constantes da Conta de Consumo de Combustíveis, e utilização do valor Normativo para utilização da regra de repasse para a tarifa.
} 
energia elétrica em conformidade com a política energética nacional, definida pelo CNPE - Conselho Nacional de Política Energética. O CCPE ficou também com a atribuição de fornecer aos agentes do mercado de energia um quadro de referência para seus planos de investimentos, através de um planejamento indicativo decenal para a expansão do parque gerador, e determinativo para a expansão da rede básica. Até então o planejamento da expansão do sistema era determinativo a cargo da Eletrobrás, conduzido pelo GCPS - Grupo Coordenador do Planejamento dos Sistemas Elétricos que foi extinto quando da conclusão do plano decenal 2000-2009 (RAMALHO, 2003)

A expansão da oferta de energia elétrica entre 1995 e 1999 decorreu da conclusão de obras iniciadas pelas estatais, sendo que a média anual de potência adicionada aos sistemas elétricos neste período foi de $2.100 \mathrm{MW}$, contra uma necessidade de 2.500 a $3.000 \mathrm{MW}$ para atender ao crescimento da demanda (SAUER, 2002). A Tabela 4.1 apresenta o acréscimo da capacidade de geração entre 1995 a 1999.

Tabela 4.1. - Acréscimo da Capacidade de Geração entre 19951999

\begin{tabular}{cccc}
\hline Realizado & Novas Centrais & $\begin{array}{c}\text { Repotenciação e } \\
\text { Ampliação }\end{array}$ & Total \\
\hline 1995 & 1.388 & 20 & 1.408 \\
1996 & 2.174 & 755 & 2.929 \\
1997 & 944 & 161 & 1.105 \\
1998 & 2.207 & 120 & 2.327 \\
1999 & 2.738 & 87 & 2.825 \\
Média & 1.890 & 229 & 2.119 \\
\hline
\end{tabular}

Fonte: Sauer, 2002.

O atraso na expansão da oferta de eletricidade e a iminência de problemas de fornecimento de energia elétrica para o período de 2001 a 2003 levaram o governo a estabelecer um Programa Prioritário de Termeletricidade - PPT, criado pelo Decreto 3.371 de 24/02/2000, visando à implantação de usinas termelétricas que apresenta em seu artigo segundo: 
I - garantia de suprimento de gás natural, pelo prazo de até vinte anos, de acordo com as regras a serem estabelecidas pelo Ministério de Minas e Energia;

Il - garantia da aplicação do valor normativo à distribuidora de energia elétrica, por um período de até vinte anos, de acordo com a regulamentação da Agência Nacional de Energia Elétrica -ANEEL;

III - garantia pelo Banco Nacional de Desenvolvimento Econômico e Social - BNDES de acesso ao Programa de Apoio Financeiro a Investimentos Prioritários no Setor Elétrico.

A Figura 4.1 indica a localização dessas térmicas e a capacidade a ser acrescentada ao sistema elétrico.

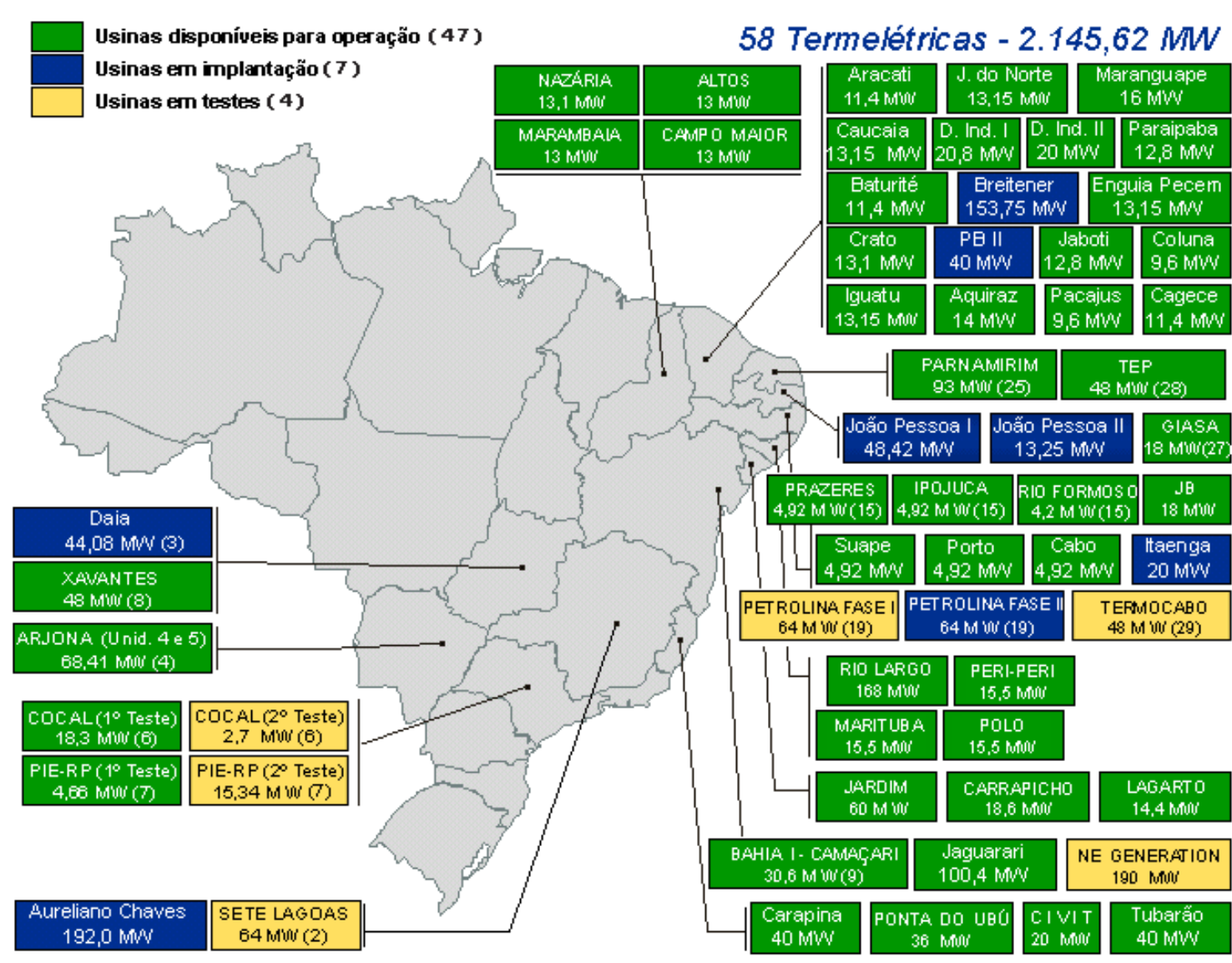

\section{Figura 4.1 - Usinas Integrantes do Programa Prioritário de Termeletricidade}

Fonte: Energia Brasil, 2000. 
A expansão insuficiente na geração de energia elétrica, conjugada com um período de pouca chuva, resultou na crise de energia elétrica de 2001, levando a um programa obrigatório de racionamento, que impôs redução de consumo para as diferentes classes, tomando por base o consumo verificado em meados de 2000.

A Figura 4.2 apresenta o nível dos reservatórios na Região Sudeste no período de 1991 a 2002. A Tabela 4.2 apresenta a redução no consumo estabelecida para as diversas classes de consumo.

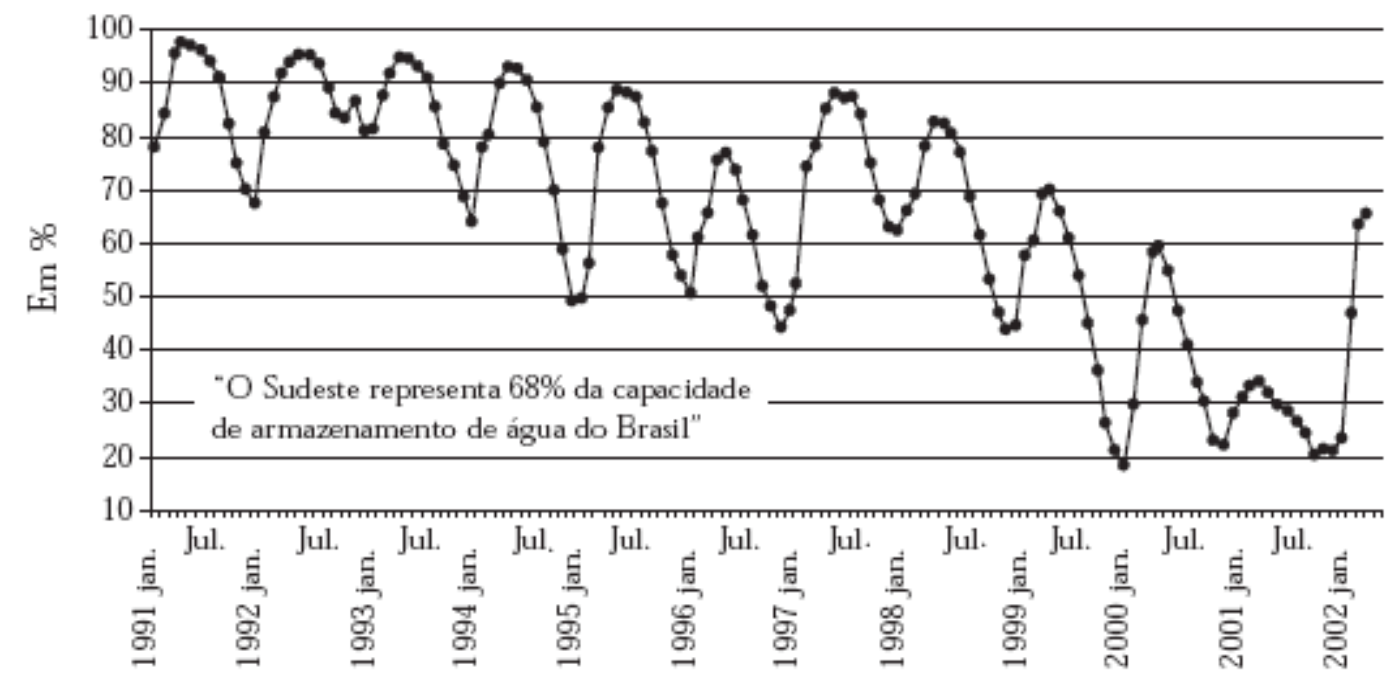

Figura 4.2 - Nível dos Reservatórios da Região Sudeste - 1991-2002

Fonte: Goldenberg, J., Prado, L.T.S., 2003. 
Tabela 4.2 - Redução no Consumo de Energia por Segmento

\begin{tabular}{|c|c|c|c|c|c|}
\hline Consumidor & $\begin{array}{c}\text { Consumo } \\
\text { em } 2000\end{array}$ & $\begin{array}{c}\text { Redução } \\
\text { de } 20 \%\end{array}$ & Sobretaxa & $\begin{array}{l}\text { Bônus } \\
\text { (a) }\end{array}$ & $\begin{array}{l}\text { Corte de } \\
\text { Forneci- } \\
\text { mento (b) }\end{array}$ \\
\hline 1-Residência & Até 100 kWh & Opcional & Não & Sim & Não \\
\hline 2-Residência & 101 a 200 kWh & Sim & Não & Sim & Sim \\
\hline 3-Residência & 201 a 500 kWh & Sim & Não(c) & Sim & Sim \\
\hline 4-Residência & Acima de $500 \mathrm{kWh}$ & Sim & Não(d) & Sim & Sim \\
\hline $\begin{array}{l}\text { 5-Indústria/Comércio } \\
\text { Alta Tensão (e) }\end{array}$ & Acima de $500 \mathrm{kWh}$ & $15 \%$ a $25 \%$ & Não & Sim & Sim \\
\hline $\begin{array}{l}\text { 6-Indústria/Comércio } \\
\text { Baixa Tensão (f) }\end{array}$ & Acima de $500 \mathrm{kWh}$ & $20 \%$ & Não & Sim & Sim \\
\hline 7-Área Rural & Sem Limite & $10 \%$ & Não & Sim & Sim \\
\hline $\begin{array}{l}8 \text { - Setor Público } \\
\text { Federal }\end{array}$ & Sem Limite & $15 \%$ a $35 \%$ & Não & Sim & Sim \\
\hline
\end{tabular}

Fonte: GCE, 2001

(a) Quem economizar acima do consumo médio ganhará desconto.

(b) Sem redução haverá corte de energia por três dias, na primeira vez, e por seis dias nas reincidências.

(c) Caso não atinjam a meta de $20 \%, 50 \%$ de multa.

(d) Caso não atinjam a meta de $20 \%, 200 \%$ de multa.

(e) A redução que for feita será cobrada pelo preço do mercado atacadista e haverá corte de fornecimento pelo número de dias necessários para recompor a meta. A empresa pode vender a parte do consumo economizada a outras empresas em leilões da distribuidora ou acumular para uso futuro, Pode, também, comprar energia de outras nos leilões.

(f) Idem nota (e).

Por meio da Medida Provisória 2.198-3, de 28 de junho de 2001 foi instalada a GCE - Câmara de Gestão da Crise de Energia Elétrica com a incumbência de propor ações para o enfrentamento da crise. A GCE foi substituída em 06 de junho de 2002 pela CGSE - Câmara de Gestão do Setor Elétrico.

A GCE adotou três ações prioritárias, além de propor o racionamento no uso da energia: (i) definição de um programa estratégico de aumento da oferta de energia elétrica; (ii) programa emergencial de aumento da oferta de energia; e (iii) revitalização do modelo do setor elétrico. (PIRES et al, 2002). Estes autores destacam que o grande mérito da GCE foi promover um engajamento de todo o governo, representado pelos Ministérios de Minas e Energia, Fazenda, Planejamento, pela AGU - Advocacia Geral da União, Aneel, ONS, BNDES, e a Eletrobrás, superando os problemas de coordenação entre os diversos órgãos governamentais.

Para avaliar a política de produção de eletricidade e identificar as causas de desequilíbrio entre a oferta e demanda, foi constituída a Comissão de Análise 
do Sistema Hidrotérmico de Energia Elétrica, através do Decreto de 22/05/2001 da Presidência da República.

As principais razões para a crise de suprimento apresentadas por esta Comissão foram: (i) hidrologia desfavorável; (ii) desequilíbrio entre oferta e demanda na partida da implantação do novo modelo para o setor; (iii) a não andamento das obras correspondente a quase dois terços da energia não aportada, (este o fator predominante para a ocorrência da crise); (iv) as energias asseguradas que respaldavam os contratos iniciais foram superdimensionadas, resultando em uma sinalização equivocada para a contratação de nova geração; (v) falta de coordenação entre os setores de eletricidade, petróleo/gás e área econômica; (vi) dentro do setor elétrico houve indefinição de responsabilidades entre o MME e a Aneel; (vii) insucesso das iniciativas governamentais para amenizar a crise; (viii) a ausência de um plano alternativo sobre o que fazer em situações hidrológicas adversas, (isso contribuiu para o agravamento e a lentidão de decisões); (ix) lacunas de atribuições e de atuação do CNPE e do MME/Secretaria de Energia; (x) dificuldades da Aneel na implementação de um ambiente regulatório adequado; (xi) atrasos e insuficiências na implementação do novo modelo setorial (MME, 2002).

O MME conduziu um programa estratégico para o aumento da oferta, propondo uma série de obras para reforçar o suprimento no período de 2001 a 2004. A Tabela 4.3 apresenta a potência instalada em 2001 e a ampliação prevista para 2004.

Tabela 4.3. Potência Instalada em 2001 e Ampliação Prevista para 2004

\begin{tabular}{|c|c|c|c|c|c|}
\hline \multicolumn{2}{|l|}{ Tipo de Geração } & \multicolumn{2}{|c|}{ Potência Instalada 2001 (MW) } & \multicolumn{2}{|c|}{ Previsão para 2004 (MW) } \\
\hline Usina Hidrelétrica & & 61.555 & $82 \%$ & 69.448 & $67 \%$ \\
\hline Usina Termelétrica & & 6.944 & $9 \%$ & 17.024 & $17 \%$ \\
\hline Usina Nuclear & & 1.966 & $3 \%$ & 1.966 & $2 \%$ \\
\hline $\begin{array}{l}\text { Fontes alternativas (Eólica, } \\
\text { Biomassa) }\end{array}$ & $\mathrm{PCH}$, & 2.345 & $3 \%$ & 5.645 & $5 \%$ \\
\hline Sub Total & & 72.810 & $92 \%$ & 94.083 & $91 \%$ \\
\hline Importação de Itaipu & & 5.500 & $7 \%$ & 6.200 & $6 \%$ \\
\hline Demais Importações & & 1.150 & 1 & 3.438 & $3 \%$ \\
\hline Total & & 79.460 & $100 \%$ & 103.721 & $100 \%$ \\
\hline
\end{tabular}

Fonte: Energia Brasil, 2002. 
As ampliações previstas por tipo de empreendimento constam na Tabela 4.4, e a localização e potência das usinas hidrelétricas para ampliação da oferta de energia estão indicadas na Figura 4.3.

Tabela 4.4 - Ampliação da Oferta 2001-2004

\begin{tabular}{|c|c|c|c|c|c|}
\hline \multirow{2}{*}{$\begin{array}{l}\text { Tipo de } \\
\text { empreendimento } \\
\text { Unidade }\end{array}$} & \multicolumn{5}{|c|}{ Ampliação da Oferta } \\
\hline & $\begin{array}{c}2001 \\
\text { Realizado }\end{array}$ & 2002 & 2003 & 2004 & Total \\
\hline Hidrelétricas (24) & 1.397 & 3.045 & 2.463 & 3.122 & 10.027 \\
\hline Termelétricas $(40)^{\star}$ & 1.354 & 2.829 & 4.342 & 916 & 9.441 \\
\hline Termelétricas & - & 2.153 & - & - & 2.153 \\
\hline \multicolumn{6}{|l|}{ Emergenciais (53) } \\
\hline Importação (5) & 98 & 1.188 & 400 & 800 & 2.486 \\
\hline PCH's (29) & 66 & 170 & 145 & - & 381 \\
\hline Cogeração (17) & 125 & 162 & 500 & - & 787 \\
\hline Eólica (42) & 2 & 261 & 394 & 393 & 1.050 \\
\hline Total (MW) & 3.042 & 9.808 & 8.244 & 5.231 & 26.325 \\
\hline
\end{tabular}

Fonte: Energia Brasil, 2002.

$\left(^{\star}\right)$ Considerada uma redução de $30 \%$ em relação ao programa previsto. 


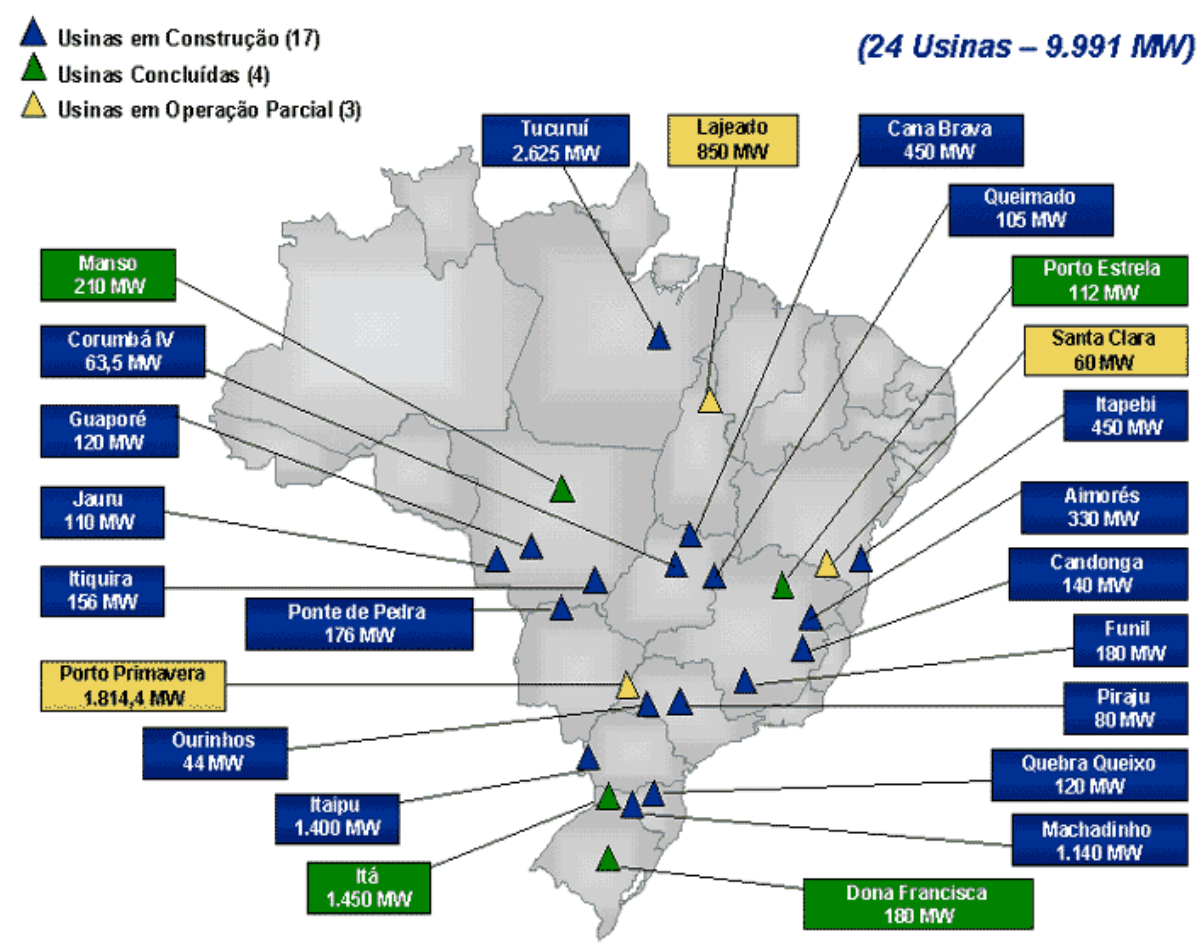

Figura 4.3 - Localização e potência das usinas hidrelétricas

Fonte: Brasil Energia, 2002.

A Tabela 4.5 apresenta a ampliação efetiva da oferta de energia elétrica, demonstrando que a ampliação prevista para o período de 2001 a 2004 não se concretizou plenamente. Havia uma projeção de chegar-se a $103.721 \mathrm{MW}$ instalado em 2004, porém foi efetivado apenas 90.733 MW. 
Tabela 4.5 - Ampliação da Oferta de Energia Elétrica ${ }^{13}$

\begin{tabular}{|c|c|c|c|c|c|c|c|c|c|c|c|c|c|}
\hline & \multicolumn{3}{|c|}{ HIDRO (1) } & \multicolumn{3}{|c|}{ TERMO } & \multicolumn{3}{|c|}{ EÓLICA (2) } & \multicolumn{2}{|l|}{ NUCLEO } & \multicolumn{2}{|c|}{ TOTAIS } \\
\hline & $\begin{array}{c}\text { SP e/ou } \\
\text { PIE }\end{array}$ & APE & TOTAL & $\begin{array}{c}\text { SP e/ou } \\
\text { PIE }\end{array}$ & APE & TOTAL & $\begin{array}{r}\text { SP e/ou } \\
\text { PIE }\end{array}$ & APE & TOTAL & $\begin{array}{l}\text { SP e/ou } \\
\text { PIE }\end{array}$ & $\begin{array}{c}\text { SP e/ou } \\
\text { PIE }\end{array}$ & APE & TOTAL \\
\hline 1974 & 13.224 & 500 & 13.724 & 2.489 & 1.920 & 4.409 & & & & & 15.713 & 2.420 & 18.133 \\
\hline 1975 & 15.815 & 501 & 16.316 & 2.436 & 2.216 & 4.652 & & & & & 18.251 & 2.717 & 20.968 \\
\hline 1976 & 17.343 & 561 & 17.904 & 2.457 & 2.223 & 4.680 & & & & & 19.800 & 2.784 & 22.584 \\
\hline 1977 & 18.835 & 561 & 19.396 & 2.729 & 2.214 & 4.943 & & & & & 21.564 & 2.775 & 24.339 \\
\hline 1978 & 21.104 & 561 & 21.665 & 3.048 & 2.259 & 5.307 & & & & & 24.152 & 2.820 & 26.972 \\
\hline 1979 & 23.667 & 568 & 24.235 & 3.573 & 2.411 & 5.984 & & & & & 27.240 & 2.979 & 30.219 \\
\hline 1980 & 27.081 & 568 & 27.649 & 3.484 & 2.339 & 5.823 & & & & & 30.565 & 2.907 & 33.472 \\
\hline 1981 & 30.596 & 577 & 31.173 & 3.655 & 2.441 & 6.096 & & & & & 34.251 & 3.018 & 37.269 \\
\hline 1982 & 32.542 & 614 & 33.156 & 3.687 & 2.503 & 6.190 & & & & & 36.229 & 3.117 & 39.346 \\
\hline 1983 & 33.556 & 622 & 34.178 & 3.641 & 2.547 & 6.188 & & & & & 37.197 & 3.169 & 40.366 \\
\hline 1984 & 34.301 & 622 & 34.923 & 3.626 & 2.547 & 6.173 & & & & & 37.927 & 3.169 & 41.096 \\
\hline 1985 & 36.453 & 624 & 37.077 & 3.708 & 2.665 & 6.373 & & & & 657 & 40.818 & 3.289 & 44.107 \\
\hline 1986 & 37.162 & 624 & 37.786 & 3.845 & 2.665 & 6.510 & & & & 657 & 41.664 & 3.289 & 44.953 \\
\hline 1987 & 39.693 & 636 & 40.329 & 3.910 & 2.665 & 6.575 & & & & 657 & 44.260 & 3.301 & 47.561 \\
\hline 1988 & 41.583 & 645 & 42.228 & 4.025 & 2.665 & 6.690 & & & & 657 & 46.265 & 3.310 & 49.575 \\
\hline 1989 & 44.172 & 624 & 44.796 & 4.007 & 2.665 & 6.672 & & & & 657 & 48.836 & 3.289 & 52.125 \\
\hline 1990 & 44.934 & 624 & 45.558 & 4.170 & 2.665 & 6.835 & & & & 657 & 49.761 & 3.289 & 53.050 \\
\hline 1991 & 45.992 & 624 & 46.616 & 4.203 & 2.665 & 6.868 & & & & 657 & 50.852 & 3.289 & 54.141 \\
\hline 1992 & 47.085 & 624 & 47.709 & 4.018 & 2.665 & 6.683 & & & & 657 & 51.760 & 3.289 & 55.049 \\
\hline 1993 & 47.967 & 624 & 48.591 & 4.127 & 2.847 & 6.974 & & & & 657 & 52.751 & 3.471 & 56.222 \\
\hline 1994 & 49.297 & 624 & 49.921 & 4.151 & 2.900 & 7.051 & & & & 657 & 54.105 & 3.524 & 57.629 \\
\hline 1995 & 50.680 & 687 & 51.367 & 4.197 & 2.900 & 7.097 & & & & 657 & 55.533 & 3.587 & 59.120 \\
\hline 1996 & 52.432 & 687 & 53.119 & 4.105 & 2.920 & 7.025 & & & & 657 & 57.194 & 3.607 & 60.801 \\
\hline 1997 & 53.987 & 902 & 54.889 & 4.506 & 2.920 & 7.426 & & & & 657 & 59.150 & 3.822 & 62.972 \\
\hline 1998 & 55.857 & 902 & 56.759 & 4.798 & 2.995 & 7.793 & & & & 657 & 61.312 & 3.897 & 65.209 \\
\hline 1999 & 58.085 & 912 & 58.997 & 5.217 & 3.309 & 8.526 & & & & 657 & 63.960 & 4.221 & 68.181 \\
\hline 2000 & 60.095 & 968 & 61.063 & 6.567 & 4.075 & 10.642 & & & & 2.007 & 68.669 & 5.043 & 73.712 \\
\hline 2001 & 61.551 & 972 & 62.523 & 7.559 & 4.166 & 11.725 & & & & 2.007 & 71.117 & 5.138 & 76.255 \\
\hline 2002 & 64.146 & 1.165 & 65.311 & 10.654 & 4.486 & 15.140 & & & & 2.007 & 76.807 & 5.651 & 82.458 \\
\hline 2003 & 66.587 & 1.206 & 67.793 & 11.693 & 5.012 & 16.705 & & & & 2.007 & 80.287 & 6.218 & 86.505 \\
\hline 2004 & 67.572 & 1.427 & 68.999 & 14.529 & 5.198 & 19.727 & & & & 2.007 & 84.108 & 6.625 & 90.733 \\
\hline 2005 & 69.274 & 1.583 & 70.858 & 14.992 & 5.272 & 20.264 & 27 & 2 & 29 & 2.007 & 86.300 & 6.858 & 93.158 \\
\hline 2006 & 71.767 & 1.666 & 73.434 & 14.285 & 6.672 & 20.957 & 235 & 2 & 237 & 2.007 & 88.294 & 8.340 & 96.634 \\
\hline 2007 & 73.622 & 3.249 & 76.871 & 14.270 & 7.055 & 21.324 & 245 & 2 & 247 & 2.007 & 90.144 & 10.305 & 100.449 \\
\hline
\end{tabular}

(1) Inclui parcela brasileira da Usina de Itaipu

(2) Série considera dados a partir de 2005. Usinas em operaçao até 2004 estão incluldas em Termo

(3) Usinas PIE e SP da ANEEL, com parcelas de APE, estáo classificadas em SP e/ou PIE.

(4) Usinas PIE da ANEEL, tradicionalmente APE, eståo classificadas em APE

Fonte: BEN, 2008.

${ }^{13}$ SP - Concessão de serviço público, PIE - Produtor Independente de Energia e APE - Auto Produtor de Energia. 


\subsection{Revitalização do Modelo Elétrico}

Através da Resolução 18, de 22 de junho de 2001 foi instituído o Comitê de Revitalização do Modelo do Setor Elétrico, integrante do Conselho Nacional de Política Energética - CNPE. Assumindo a responsabilidade de encaminhar propostas para corrigir as disfunções existentes e aperfeiçoar o modelo do setor elétrico. Os trabalhos foram direcionados para preservar os pilares básicos de funcionamento do setor elétrico, sendo estes: (i) competição nos segmentos de geração e comercialização de energia elétrica; (ii) expansão dos investimentos com base em aportes da iniciativa privada; e (iii) regulação dos segmentos que são monopólios naturais (transmissão e distribuição de energia elétrica), de forma a garantir a qualidade dos serviços e o suprimento de energia elétrica compatíveis com as necessidades de desenvolvimento do país (Energia Brasil, 2002a).

As atividades do Comitê de Revitalização foram agrupadas, no Relatório de Progresso $n^{0} 4$, em oito temas gerais: a) analisar o funcionamento do setor elétrico; b) aperfeiçoamento do mercado de energia elétrica; c) garantia de expansão da oferta; d) monitoração da confiabilidade de suprimento; e) política energética; f) questões relativas à transmissão; g) política tarifária e defesa da concorrência; h) aperfeiçoamento institucional do MAE e ONS (MME, 2002).

Dentre as atividades de revitalização merece destaque o Acordo Geral do Setor que restabeleceu o equilíbrio econômico-financeiro das distribuidoras que fora abalado pelo racionamento de energia elétrica. Editado através da Medida Provisória 14, de 21 de dezembro de 2001, convertida na Lei 10.438/2002, o acordo estabeleceu a RTE - Recomposição Tarifária Extraordinária inserida dentro do tema Normalização do Funcionamento do Setor Elétrico (RAMALHO, 2003)

Foi aplicado um aumento nas tarifas de energia elétrica de 2,9\% a.a. para os consumidores residenciais, e de 7,9\% a.a. para os consumidores industriais, com os prazos de vigência deste aumento variando de acordo com as características de cada concessionária, sendo que os consumidores classificados como Baixa Renda não tiveram nenhum aumento. 
Também foi criada a Conta de Compensação de Variação de Valores de Itens da Parcela A - CVA ${ }^{14}$ instituída pela Portaria Ministerial $n^{\circ} 296$, de 26 de outubro de 2001. A CVA criou mecanismos de compensação para os cálculos dos reajustes tarifários do fornecimento de energia elétrica em função das variações ocorridas nos itens da Parcela $A$, ou seja, custos não gerenciáveis pela empresa fornecedora de energia na composição da tarifa. Coube à Aneel fiscalizar, validar e aprovar os valores contabilizados na CVA, para efeito de repasse às tarifas de energia elétrica, de modo a garantir que as perdas de receitas registradas não sobrecarregassem o consumidor final (RAMALHO, 2003).

De 2001 até 2004 outras medidas foram adotadas através de leis e decretos para a revitalização do setor elétrico. Em 21 de agosto de 2001 o Decreto no 3.900 cria a Comercializadora Brasileira de Energia Emergencial.

A Lei 10.438/02, dispôs sobre a expansão da oferta de energia emergencial. Dispôs, também, que os custos, inclusive de natureza operacional, tributária e administrativa, relativos à aquisição de energia elétrica $(k W h)$ e à contratação de capacidade de geração ou potência $(\mathrm{kW})$ pela Comercializadora Brasileira de Energia Emergencial - CBEE sejam rateados entre todas as classes de consumidores finais, atendidas pelo Sistema Elétrico Nacional Interligado, mediante adicional tarifário específico, segundo regulamentação da Aneel. Também através desta Lei foram instituídos os Proinfa - Programa de Incentivo às Fontes Alternativas de Energia Elétrica e a CDE - Conta de Desenvolvimento Energético (BRASIL, 2002)

A Lei $n^{\circ} 10.433$ de 24/04/2002 alterou o funcionamento do Mercado Atacadista de Energia que ficou submetido a autorização, regulamentação e fiscalização pela Aneel. Passou a ser integrado por titulares de concessão, permissão ou autorização e outros agentes, na forma da regulamentação, vinculados aos serviços e às instalações de energia elétrica, com a finalidade de viabilizar as transações de compra e venda de energia elétrica nos sistemas interligados (BRASIL, 2002a).

\footnotetext{
${ }^{14}$ A estrutura tarifária no novo modelo do setor elétrico é tratada no Capítulo 5.
} 
Em fevereiro de 2003 o Ministério das Minas e Energia, por meio da Portaria MME $\mathrm{n}^{\circ} 40$ criou um grupo de trabalho com o objetivo de assessorar na formulação e implantação da reforma institucional do setor elétrico.

O Conselho Nacional de Política Energética aprova em 10 de dezembro de 2003 a Resolução CNPE no 9 que apresenta propostas para medidas legais pertinentes e necessárias para a implantação do novo modelo do setor elétrico, na seqüência foram editadas duas medidas provisórias.

A MP 144 alterou o marco institucional e regulatório do Setor Elétrico Brasileiro, foi convertida na Lei 10.848 de 15/03/2004, que dentre outras medidas, adotou dois ambientes para a contratação de energia para os consumidores: Ambiente de Contratação Regulada - ACR e o Ambiente de Contratação Livre - ACL.

A segunda medida, a MP $n^{\circ} 145$, convertida na Lei 10.847 em 15/03/2004, aprovou a criação da Empresa de Pesquisa Energética - EPE e determina que a EPE tenha como principais atribuições a realização de estudos e pesquisas de planejamento energético de longo prazo, horizonte não inferior a 20 anos; e de médio prazo, neste caso de dez anos.

Os desdobramentos destes estudos e pesquisas resultam no Plano Decenal da Expansão dos Sistemas Elétricos - PDE, e no Programa Determinativo da Expansão da Transmissão - PDET, com atualização anual (BRASIL, 2004).

É também uma atribuição da EPE conceder a Licença Ambiental Prévia - LP para os novos empreendimentos que ofertarão energia nos leilões futuros. A obtenção da LP evita problemas como os verificados anteriormente, quando as concessões não conseguiam, depois de licitadas, obter a LP indispensável para seu início, prejudicando a expansão do setor (AMARAL FILHO, 2007).

O decreto $\mathrm{n}^{\circ}$ 5.163, de 30 de julho de 2004 veio regulamentar a Lei $\mathrm{n}^{\circ}$ 10.848/04, introduzindo alterações na estrutura e modo de funcionamento do setor elétrico.

Uma das alterações foi que, até a publicação do Decreto, tinha-se por consumidor com potencial de contratar livremente seu fornecimento de energia elétrica aquele cuja carga fosse igual ou superior a $3 \mathrm{MW}$, desde que atendido em tensão igual ou superior a $69 \mathrm{kV}$ e estivesse conectado no sistema antes de 
8 de julho de 1995, ou ainda, se atendido em qualquer nível de tensão, porém estivesse conectado após a mesma data, mantida a obrigatoriedade de ter uma demanda contratada mínima de 3 MW.

De acordo com Camargo (2005), nesta disposição, o consumidor que possuísse carga igual ou superior a $3 \mathrm{MW}$, que fosse atendido em tensão inferior a 69 kV e tenha sido ligado antes de julho de 1995 não teria a prerrogativa de contratar livremente seu fornecimento de energia elétrica. Esse autor enfatiza que:

a má técnica utilizada pelo legislador ao definir consumidor potencialmente livre possibilitou uma interpretação dúbia deste instituto que fora habilmente explorada pelas partes interessadas nesta definição, cada qual interpretando de maneira mais favorável para si.

Em 20 de outubro de 2004, através do decreto $n^{0} 5.249$, foi dada uma nova definição ao consumidor potencialmente livre:

é aquele que, a despeito de cumprir as disposições estabelecidas no art. 15 da Lei 9.074 de 1995, é atendido de forma regulada.

A alteração havida na definição de consumidor potencialmente livre decorreu, de acordo com declaração feita por Maurício Tomasquim em matéria publicada no Valor Econômico em 22/10/2004, da possibilidade de um desequilíbrio econômico-financeiro caso consumidores de menor porte migrassem para 0 mercado livre (Camargo, 2005).

O Decreto 5.163/2004 estabeleceu que a comercialização de energia elétrica entre concessionários, permissionários e autorizados de serviços e instalações de energia elétrica, bem como destes com seus consumidores no Sistema Interligado Nacional - SIN passassem a ocorrer nos Ambientes de Contratação Regulada ou Livre.

Estava prevista na Lei 10.848/04 a criação da Câmara de Comercialização de Energia Elétrica - CEEE, que veio a substituir o Mercado Atacadista de Energia. Regulamentada pelo Decreto $\mathrm{n}^{\circ}$ 5.177, de 12 de agosto de 2004. A CCEE tem por finalidade viabilizar a comercialização de energia elétrica no Sistema Interligado Nacional nos Ambientes de Contratação Regulada e 
Contratação Livre, além de efetuar a contabilização e a liquidação financeira das operações realizadas no mercado de curto prazo, as quais são auditadas externamente, nos termos da Resolução Normativa Aneel $n^{0}$ 109, de 26 de outubro de 2004 (Convenção de Comercialização de Energia Elétrica). As Regras e os Procedimentos de Comercialização que regulam as atividades realizadas na CCEE são aprovados pela Aneel (BRASIL, 2004 a).

A representação na CCEE dos consumidores regulados é feita através das suas respectivas distribuidoras, que formam a categoria "distribuição" na Câmara, existindo, ainda, a categoria de geração e de comercialização.

A categoria "geração" é formada por geradores, produtores independentes e autoprodutores, sendo que estes agentes podem vender energia tanto no Ambiente de Contratação Regulada ou no Ambiente de Contratação Livre, possuindo livre acesso aos sistemas de transmissão e distribuição de energia elétrica, pagando pelo uso destes sistemas.

$\mathrm{Na}$ categoria "comercialização" encontram-se agentes importadores e exportadores, além de comercializadores e consumidores livres.

O Ambiente de Contratação Regulada - ACR é o segmento do mercado no qual se realizam operações de compra e venda de energia elétrica entre os agentes vendedores e os agentes de distribuição, precedidas de licitação, ressalvados os casos previstos em lei, conforme regras e procedimentos de comercialização específicos (BRASIL, 2004b).

Neste ambiente as distribuidoras em conjunto contratam energia para atender seu mercado, seus consumidores, através de leilões de energia, com regras pré-estabelecidas, sendo os vencedores aqueles que ofereçam pelo menor preço, a energia proveniente das usinas existentes e das usinas a serem construídas.

Com esta modalidade de contratação de energia, pelo lado das distribuidoras, de acordo com Amaral Filho (2007), elimina-se a competição de preços de energia no mercado, eliminando a competição entre geradores, prevista no modelo apresentado pela Coopers \& Lybrand, a geração é incorporada ao 
sistema interligado, priorizando a energia mais barata que passa a fazer parte de um pool de geração.

O Ambiente de Contratação Livre - ACL é o segmento do mercado no qual se realizam as operações de compra e venda de energia elétrica, objeto de contratos bilaterais livremente negociados, conforme regras e procedimentos de comercialização específicos (BRASIL, 2004b).

Neste ambiente os consumidores livres contratam a energia que necessitam diretamente dos vendedores ( basicamente de produtores independentes e comercializadores) sob condições livremente pactuadas, por meio de contratos bilaterais estabelecidos entre as partes. A contratação deve ser integral, para cobertura de $100 \%$ de sua carga, e caso isso não ocorra estarão sujeitos a penalidade (Amaral Filho, 2007).

Os agentes vendedores devem apresentar lastro para a venda de energia e garantir a plena execução de seus contratos, a partir da data de publicação do Decreto 5.163/2004. A Figura 4.4 apresenta o crescimento da migração de consumidores para o ACL e a Figura 4.5 a evolução dos consumidores livres.

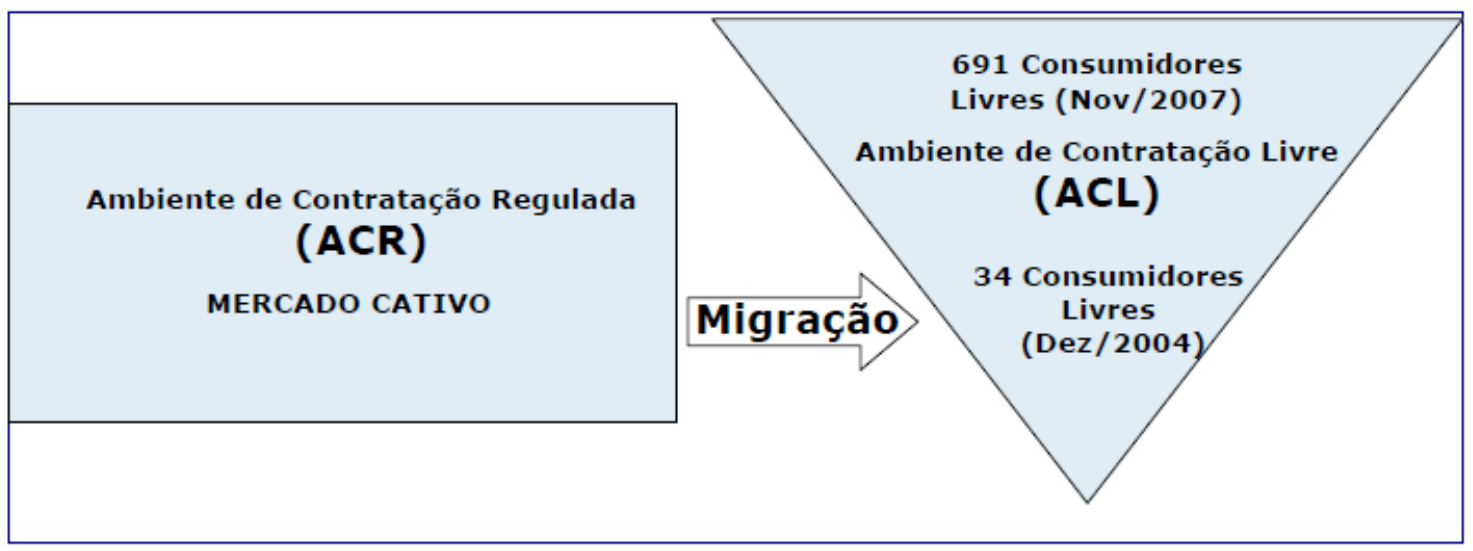

Figura 4.4 - Crescimento da Migração de Consumidores para o ACL Fonte: Aguiar, 2008. 


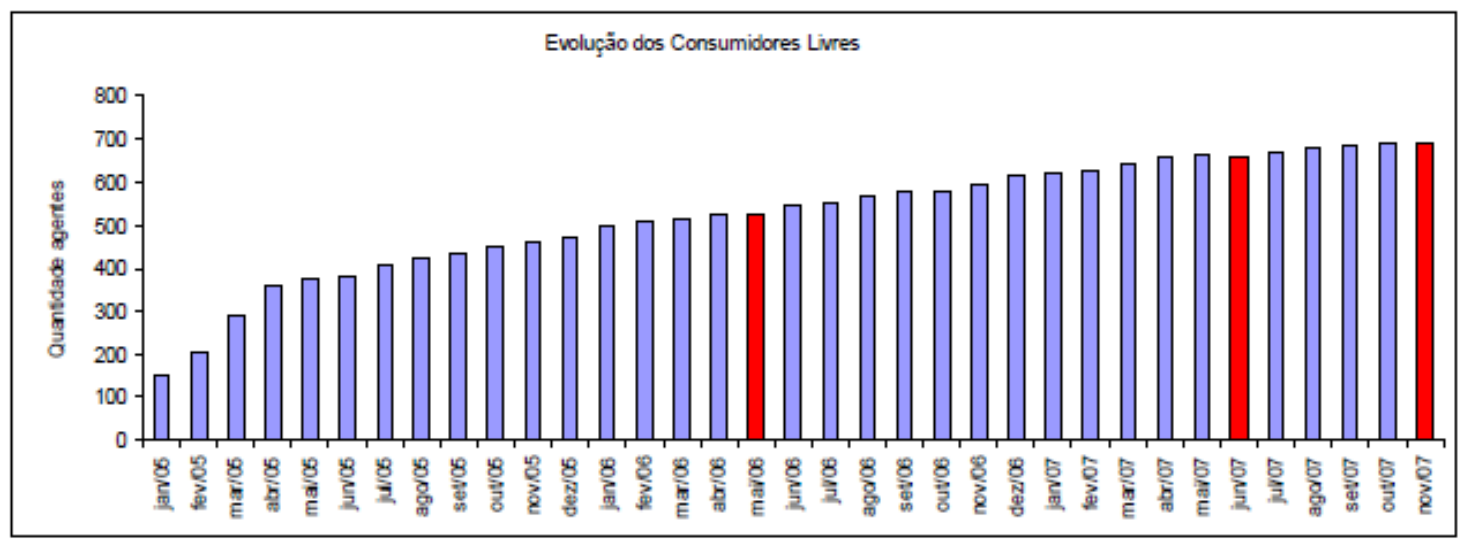

Figura 4.5 - Evolução dos Consumidores Livres

Fonte: Aguiar, 2008.

Nota-se que o aquecimento do mercado livre inicia-se em 2005 dentro de um ambiente regulatório melhor definido pela Lei 10.848/2004 e regulamentos subseqüentes.

Para Aguiar (2008), o crescimento do número de consumidores livres deu-se em decorrência de dois fatores: primeiro, o consumidor livre por determinação legal teve que passar a ser agente de mercado, fato que antes não era exigido, ou seja, era possível que um determinado consumidor tivesse seus pontos de consumo modelados em nome de um representante, um comercializador. $\mathrm{O}$ segundo fator que impulsionou este crescimento deveu-se ao fato de desde 2003 ter havido uma sobre oferta de energia e os preços praticados no ACL estavam bem abaixo das tarifas do ambiente regulado. De acordo com o mesmo autor, as quedas verificadas em maio/2006, junho de 2007 e novembro de 2007 podem estar atribuídas ao retorno de alguns agentes ao ambiente regulado.

A diminuição da participação de consumidores no mercado livre continuou durante o ano de 2008 e nos dois primeiros meses de 2009, conforme demonstrado na tabela 4.6. 


\section{Tabela 4.6 - Evolução da Operação dos Agentes Consumidores Livres na CCEE $(*)$}

\begin{tabular}{cccc}
\hline Mês/ano & Agentes & Consumo (MW médio) & \% de Consumo na CEEE \\
\hline Fev/08 & 675 & 8.592 & $16,93 \%$ \\
Mar/08 & 681 & 8.693 & $17,04 \%$ \\
Abr/08 & 685 & 8.678 & $17,06 \%$ \\
Mai/08 & 678 & 8.779 & $17,57 \%$ \\
Jun/08 & 676 & 8.852 & $17,39 \%$ \\
Jul/08 & 667 & 8.842 & $17,52 \%$ \\
Ago/08 & 663 & 8.748 & $17,04 \%$ \\
Set/08 & 654 & 8.637 & $16,74 \%$ \\
Out/08 & 658 & 8.766 & $16,62 \%$ \\
Nov/08 & 650 & 8.231 & $16,14 \%$ \\
Dez/08 & 651 & 7.117 & $14,86 \%$ \\
Jan/09 & 658 & 7.352 & $15,22 \%$ \\
Fev/09 & 643 & 7.658 & $15,11 \%$ \\
\hline Fon
\end{tabular}

Fonte: CCEE, 2009

${ }^{*}$ ) Não inclui o consumo de consumidores com geração própria (autoprodutores e produtores independentes) e de consumidores finais atendidos com tarifa regulada pelas geradoras Chesf, Furnas e Eletronorte.

O estudo deste decréscimo deverá ser aprofundado em trabalhos futuros, comparando a variação das tarifas nos ambientes livre e regulado, bem como a forma de participação das empresas no CCEE.

Ao participar do mercado livre o consumidor assume responsabilidades em relação a sua exposição aos preços de energia, porém tem a oportunidade de ser atendido de forma individual, conforme suas características de consumo, o que não é permitido no mercado cativo (ABRACEEL, 2006).

Para os consumidores cuja carga seja maior ou igual a $500 \mathrm{~kW}$ e que comprem energia de $\mathrm{PCH}$, usinas de biomassa, eólica ou solar, celebrando contrato de compra e venda de energia diretamente com a usina, há desconto na Tarifa de Uso do Sistema de Distribuição, conforme resoluções normativas da Aneel.

Não existem diferenças entre consumidores livres e regulados no tocante à qualidade de energia e à segurança de sua oferta. No mercado regulado, o distribuidor é o fornecedor da energia, com tarifas definidas isonomicamente para uma mesma classe de consumo, aplicadas durante um ano para a data de reajuste ou revisões tarifárias subseqüentes. Para o consumidor livre, a energia 
é livremente negociada sendo que o seu valor é resultante de sua opção de compra, que poderá incluir contratos de diferentes prazos e maior ou menor exposição ao preço de curto prazo. O consumidor, no mercado livre, é responsável pelos seus erros e acertos na decisão de contratação, tomando para si a tarefa de gerir suas compras de energia e os riscos associados (ABRACEEL, 2006).

Em 2007 a Aneel publica a Resolução 247/07 que estabelece as condições para a comercialização de energia elétrica, oriunda de empreendimentos de geração que utilizem fontes primárias incentivadas, com unidade ou conjunto de unidades consumidoras cuja carga seja maior ou igual a $500 \mathrm{~kW}$ e aprova as regras de comercialização de energia elétrica através da Resolução 293/07.

A dinâmica da comercialização de energia no mercado livre e cativo pode ser observada através da Figura 4.6

\section{Resoluções Normativas $n^{0} 247 / 07$ e $n^{0}$ 293/07}

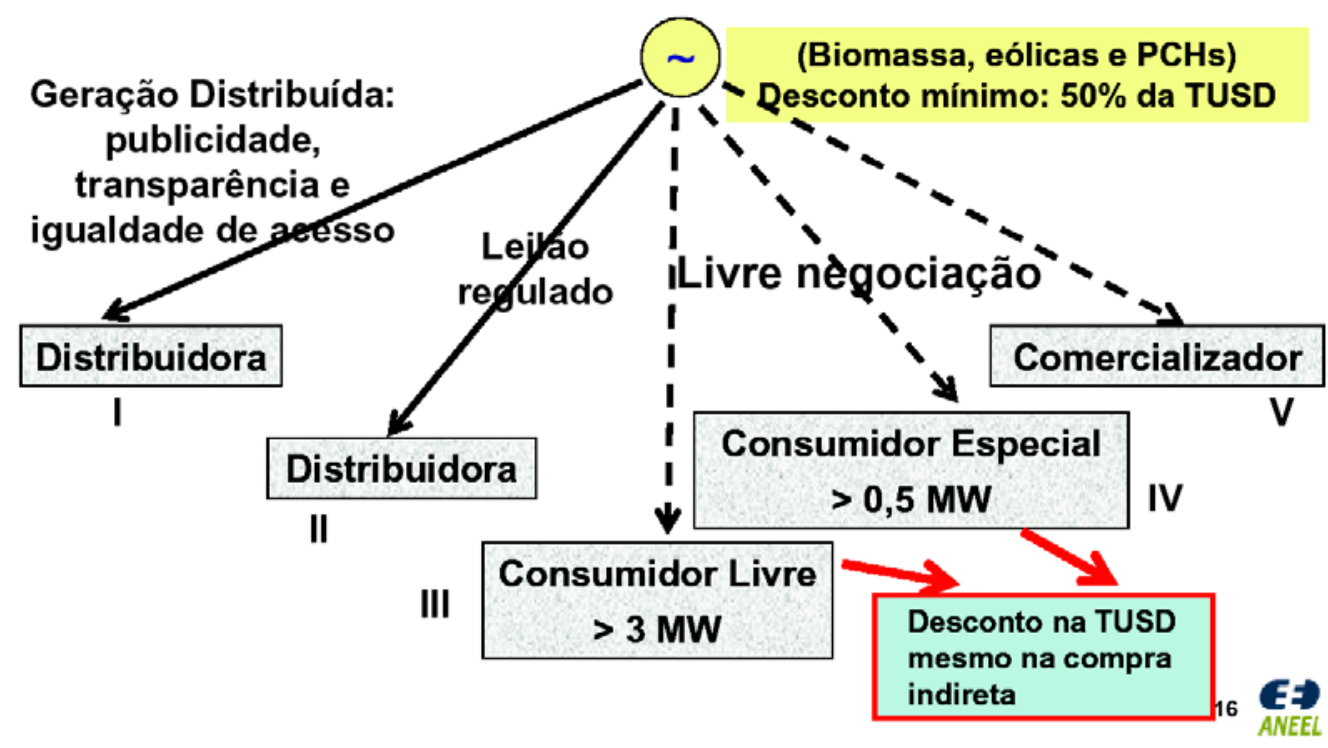

Figura 4.6 - Comercialização de Energia

Fonte: Aneel, 2008.

As instituições que passaram a compor o setor elétrico, conforme o novo modelo: 
MME - Ministério de Minas e Energia - Responsável pela formulação e implementação de políticas para o setor energético de acordo com as diretrizes do CNPE;

CNPE - Conselho Nacional de Política Energética, responsável pela homologação da política energética em articulação com as demais políticas públicas;

CMSE - Monitorar condições de atendimento, ações preventivas para garantir segurança do suprimento;

EPE - Empresa de Pesquisa Energética, responsável pela execução de estudos para definição da Matriz Energética e Planejamento da expansão do setor elétrico - geração e transmissão;

Aneel - Agência Nacional de Energia Elétrica responsável pela regulação, qualidade dos serviços, tarifas de consumidores cativos, universalização do atendimento, viabilidade econômica e financeira dos agentes de comercialização;

ONS - Operador Nacional do Sistema Elétrico, responsável pela coordenação e controle da operação da geração e transmissão no sistema elétrico interligado;

CCEE - Câmara de Comercialização de Energia Elétrica que administra os contratos, liquidação do mercado de curto prazo e leilões de energia.

A Câmara de Comercialização de Energia tem ainda como atribuições:

- Manter o registro de todos os contratos fechados nos Ambientes de Contratação Regulada (ACR) e de Contratação Livre (ACL);

- Promover a medição e registro dos dados de geração e consumo de todos os Agentes da CCEE;

- Apurar o Preço de Liquidação de Diferenças - PLD - do Mercado de Curto Prazo por submercado ${ }^{15}$;

\footnotetext{
${ }^{15}$ Submercado de Energia: Subdivisões do sistema interligado, correspondentes às áreas de mercado para as quais a CCEE estabelece preços diferenciados para a energia. Existem quatro submercados Norte, Nordeste, Sudeste/Centro-Oeste e Sul.
} 
- Efetuar a Contabilização dos montantes de energia elétrica comercializados no Mercado de Curto Prazo e a Liquidação Financeira;

- Apurar o descumprimento de limites de contratação de energia elétrica e outras infrações e, quando for o caso, por delegação da Aneel, nos termos da Convenção de Comercialização, aplicar as respectivas penalidades;

- Apurar os montantes e promover as ações necessárias para a realização do depósito, da custódia e da execução de Garantias Financeiras, relativas às Liquidações Financeiras do Mercado de Curto Prazo, nos termos da Convenção de Comercialização;

- $\quad$ Promover Leilões de Compra e Venda de energia elétrica, conforme delegação da Aneel;

- $\quad$ Promover o monitoramento das ações empreendidas pelos Agentes, no âmbito da CCEE, visando à verificação de sua conformidade com as Regras e Procedimentos de Comercialização, e com outras disposições regulatórias, conforme definido pela Aneel;

- Executar outras atividades, expressamente determinadas pela Aneel, pela Assembléia Geral ou por determinação legal, conforme 0 art. $3^{\circ}$ do Estatuto Social da CCEE.

Esta nova configuração do setor elétrico culminou com a primeira revisão tarifária de grande número de distribuidoras em 2003. Nesta revisão inicia-se o processo de realinhamento tarifário. Este processo, associado à elevação das tarifas de energia elétrica acima dos índices oficiais de reajuste, fizeram com que o segmento industrial se voltasse para melhor compreensão das tarifas de energia nos ambientes de contratação e opções tarifárias. Tarifas e estrutura tarifária são temas tratados no capítulo seguinte. 


\section{CAPÍTULO 5}

\section{TARIFAS E REVISÃO TARIFÁRIA - COMPONENTES E FORMA DE APLICAÇÃO}

Os consumidores, para efeito de aplicação das tarifas de energia elétrica, são identificados por classe e subclasses de consumo, que levam em conta dois componentes: a demanda de potência e consumo de energia, sendo as tarifas estruturadas em dois grandes grupos: "A" e "B".

Os Consumidores do Grupo A são grupos compostos de unidades consumidoras com fornecimento em tensão igual ou superior a 2,3 kV, ou quando atendidas em tensão inferior a 2,3 kV alimentados a partir de sistema subterrâneo de distribuição serão faturados neste Grupo nos termos definidos no art. 82 da Resolução Aneel 456/2000, caracterizado pela estruturação tarifária binômia ${ }^{16}$ e subdividido nos seguintes subgrupos:

a) Subgrupo A1 - tensão de fornecimento igual ou superior a $230 \mathrm{kV}$;

b) Subgrupo A2 - tensão de fornecimento de $88 \mathrm{kV}$ a $138 \mathrm{kV}$;

c) Subgrupo A3 - tensão de fornecimento de $69 \mathrm{kV}$;

d) Subgrupo A3a - tensão de fornecimento de $30 \mathrm{kV}$ a $44 \mathrm{kV}$;

e) Subgrupo A4 - tensão de fornecimento de $2,3 \mathrm{kV}$ a $25 \mathrm{kV}$;

f) Subgrupo AS - tensão de fornecimento inferior a 2,3 kV, atendidas a partir de sistema subterrâneo de distribuição e faturadas neste Grupo em caráter opcional (ANEEL, 2000).

\footnotetext{
${ }^{16}$ Conjunto de tarifas de fornecimento constituído por preços aplicáveis ao consumo de energia elétrica ativa e à demanda faturável.
} 
Os consumidores do Grupo "B" são grupos compostos de unidades consumidoras com fornecimento em tensão inferior a 2,3 kV, ou, ainda, atendidas em tensão superior a 2,3 kV e faturadas neste Grupo, caracterizado pela estruturação tarifária monômia ${ }^{17}$, ou seja, uma única tarifa aplicada durante todo o período do dia e época do ano (ANEEL, 2000).

Até 1988 existia uma única estrutura tarifária para o setor industrial, denominada estrutura tarifária convencional, caracterizada pela aplicação de tarifas de consumo de energia e/ou demanda de potência independentemente das horas de utilização do dia e dos períodos do ano. Esta tarifa apresenta um valor para a demanda de potência em reais por kW e outro para o consumo de energia em reais por MWh, que esquematicamente está demonstrada na Figura 5.1.

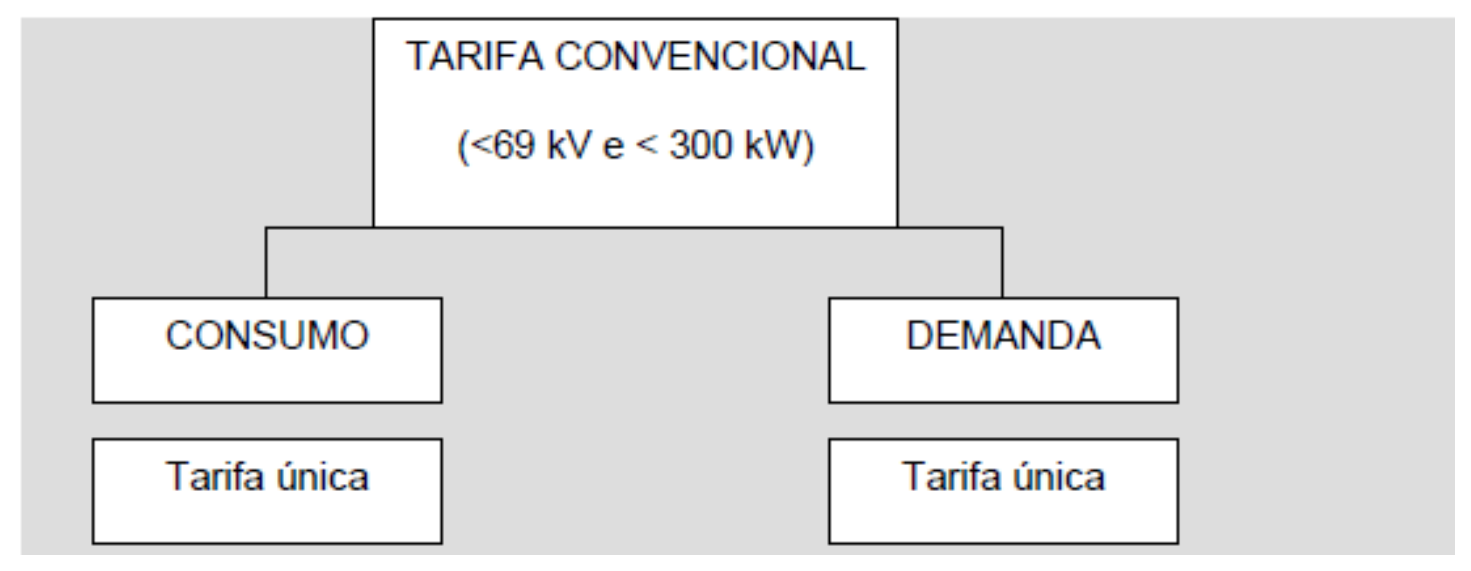

Figura 5.1 - Estrutura Tarifária Convencional

Fonte: Aneel, apud Aguiar, 2008

Através da Portaria $n^{\circ}$ 33, de 11 de fevereiro de 1988 o DNAEE implanta a estrutura tarifária horo-sazona ${ }^{18}$, adotando tarifas diferenciadas para demanda de potência e consumo de energia conforme os períodos do ano e os horários de utilização. O objetivo dessa estrutura tarifária é o de racionalizar o consumo

\footnotetext{
${ }^{17}$ Tarifa de fornecimento de energia elétrica constituída por preços aplicáveis unicamente ao consumo de energia elétrica ativa.

${ }^{18}$ Em 2000 a ANEEL publicou a Resolução 456, que regulamenta, dentre outros serviços, a aplicação da tarifa horo-sazonal.
} 
de energia ao longo do dia e do ano, motivando o consumidor, pelo valor diferenciado das tarifas, a consumir mais energia elétrica nos horários do dia e nos períodos do ano em que ela for mais barata.

O gráfico apresentado na Figura 5.2 exemplifica o registro da utilização da energia elétrica ao longo de um dia útil, no SIN - Sistema Interligado Nacional, identificando os patamares de carga, leve, médio e pesado, ao longo de um dia útil.

Neste caso os períodos representados pelos patamares médio e Leve correspondem ao horário fora ponta e o período representado pelo patamar pesado corresponde ao horário de ponta.

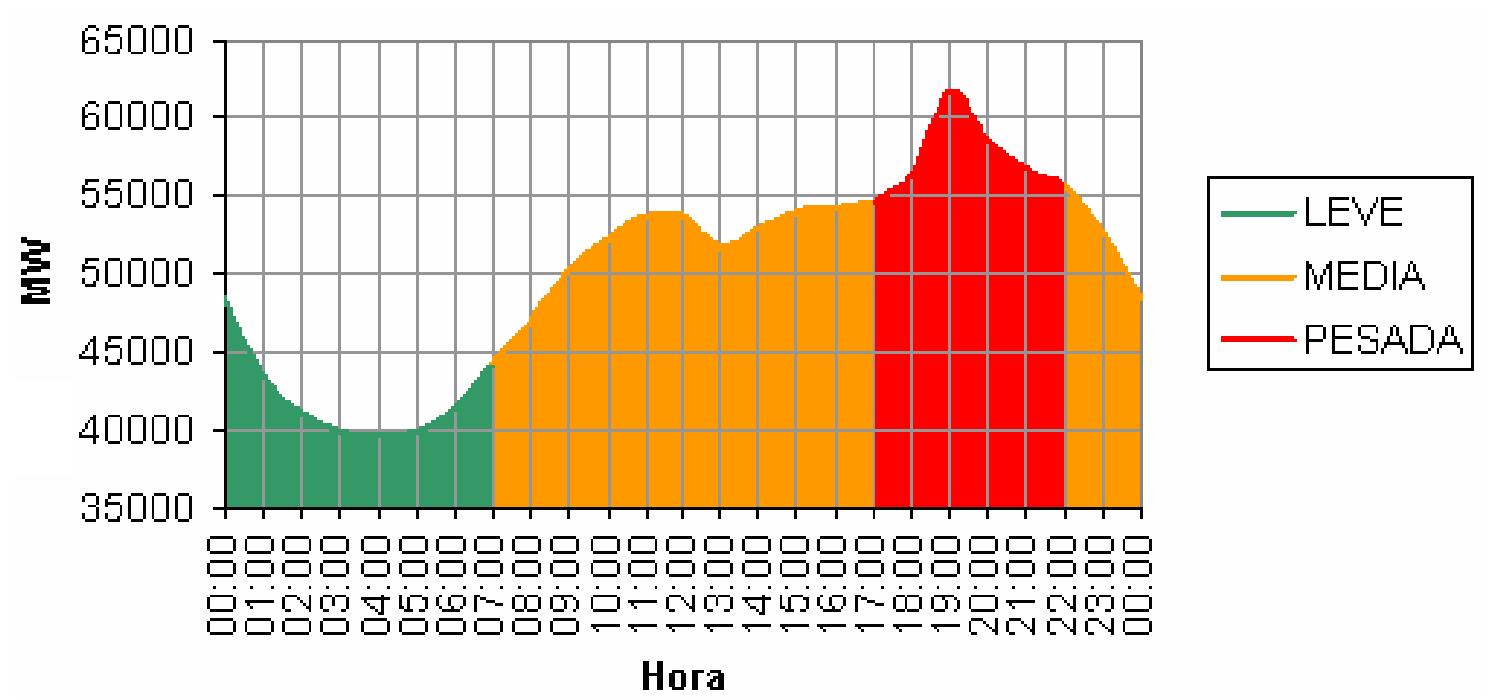

Figura 5.2 - Curva de Carga do SIN

Fonte: PUC-RIO teses abertas, 2007

O impacto da adoção da estrutura horo-sazonal está demonstrado na Figura 5.3 na sequencia. 


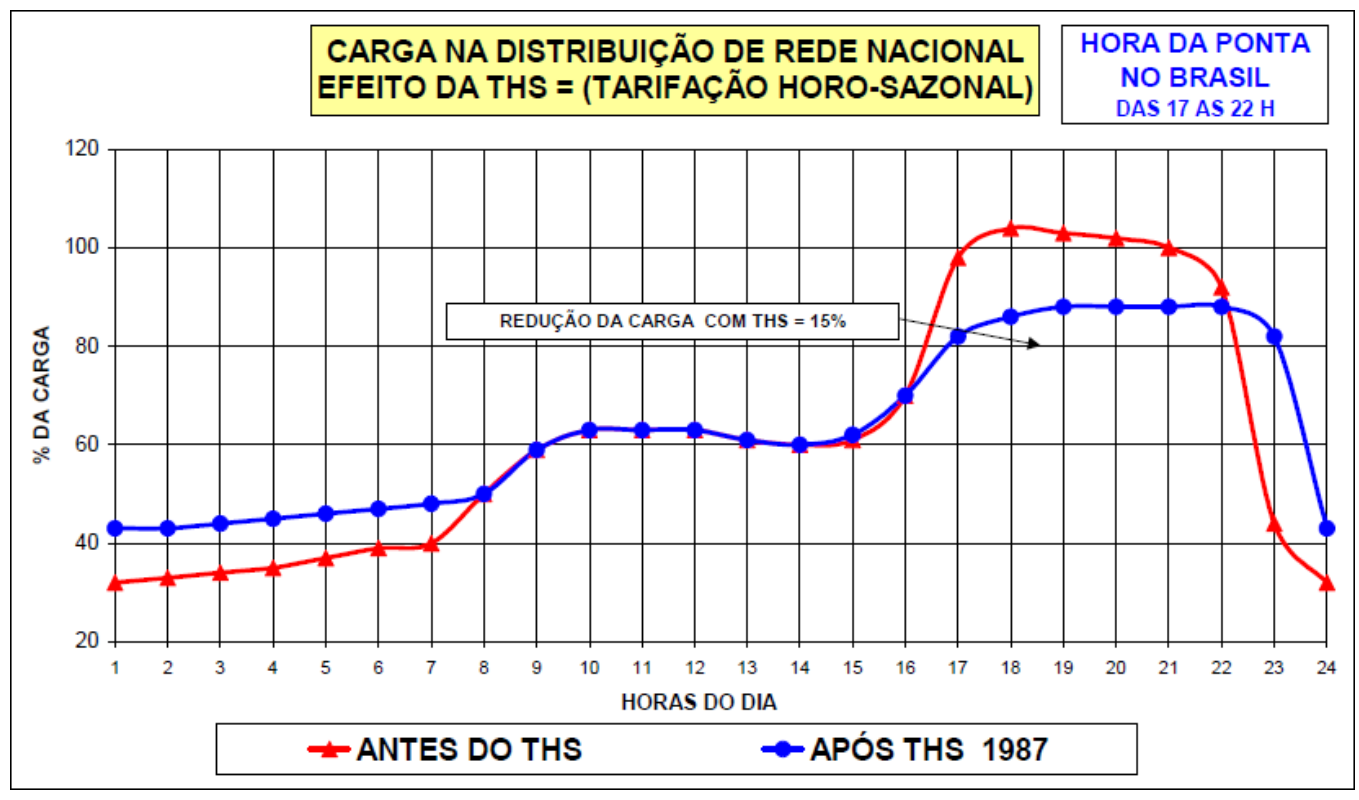

Figura 5.3 - Efeito tarifas Horo - Sazonal (THS)

Observa-se que no horário das 17 às 22 horas existe um aumento do uso da eletricidade devido a diversos fatores, dentre estes a maior utilização de chuveiros, iluminação pública e o consumo de indústrias que permanecem trabalhando neste período.

Para as horas do dia são estabelecidos dois períodos, denominados postos tarifários. O posto tarifário "ponta" corresponde ao período de maior consumo de energia elétrica, que são três horas entre 17 e 22 horas, dependendo da concessionária que o consumidor esteja conectado, conforme apresentado na figura 5.3 e o "fora de ponta" que compreende as demais horas dos dias úteis e as 24 horas dos sábados, domingos e feriados, sendo as tarifas do horário de ponta mais elevadas do que do horário fora de ponta.

A disponibilidade de água é outro componente que afeta o mercado elétrico. Assim, quando da adoção das tarifas horo-sazonais, além da variação do consumo de energia nos períodos Ponta e Fora de Ponta, adotou-se o período seco e úmido em função da disponibilidade hídrica.

O Período Seco, compreendido entre os meses de maio a novembro, é a época do ano em que a disponibilidade dos mananciais é mínima. Durante os 
meses de dezembro de um ano até abril do ano seguinte, considera-se período úmido pois existe uma maior precipitação pluviométrica.

A tarifa horo-sazonal azul é a modalidade de fornecimento estruturada para a aplicação de tarifas diferenciadas de consumo de energia, de acordo com as horas de utilização do dia e dos períodos do ano, bem como de tarifas diferenciadas de demanda de potência de acordo com as horas de utilização do dia. Esta tarifa é aplicável obrigatoriamente às unidades consumidoras atendidas pelo sistema interligado, e com tensão de fornecimento igual ou superior a $69 \mathrm{kV}$.

A estrutura tarifária horo-sazonal azul contempla um valor para a demanda de potência $(R \$ / k W)$ para o horário de ponta $(P)$ e outro para o horário fora de ponta (FP).

Quanto ao consumo de energia $(\mathrm{R} \$ / \mathrm{MWh})$ a estrutura tarifária contempla também valores diferenciados: horário de ponta em período úmido (PU); horário fora de ponta em período úmido (FPU); horário de ponta em período seco (PS); e horário fora de ponta período seco (FPS).

A estrutura horo-sazonal azul está sintetizada na Figura 5.4.

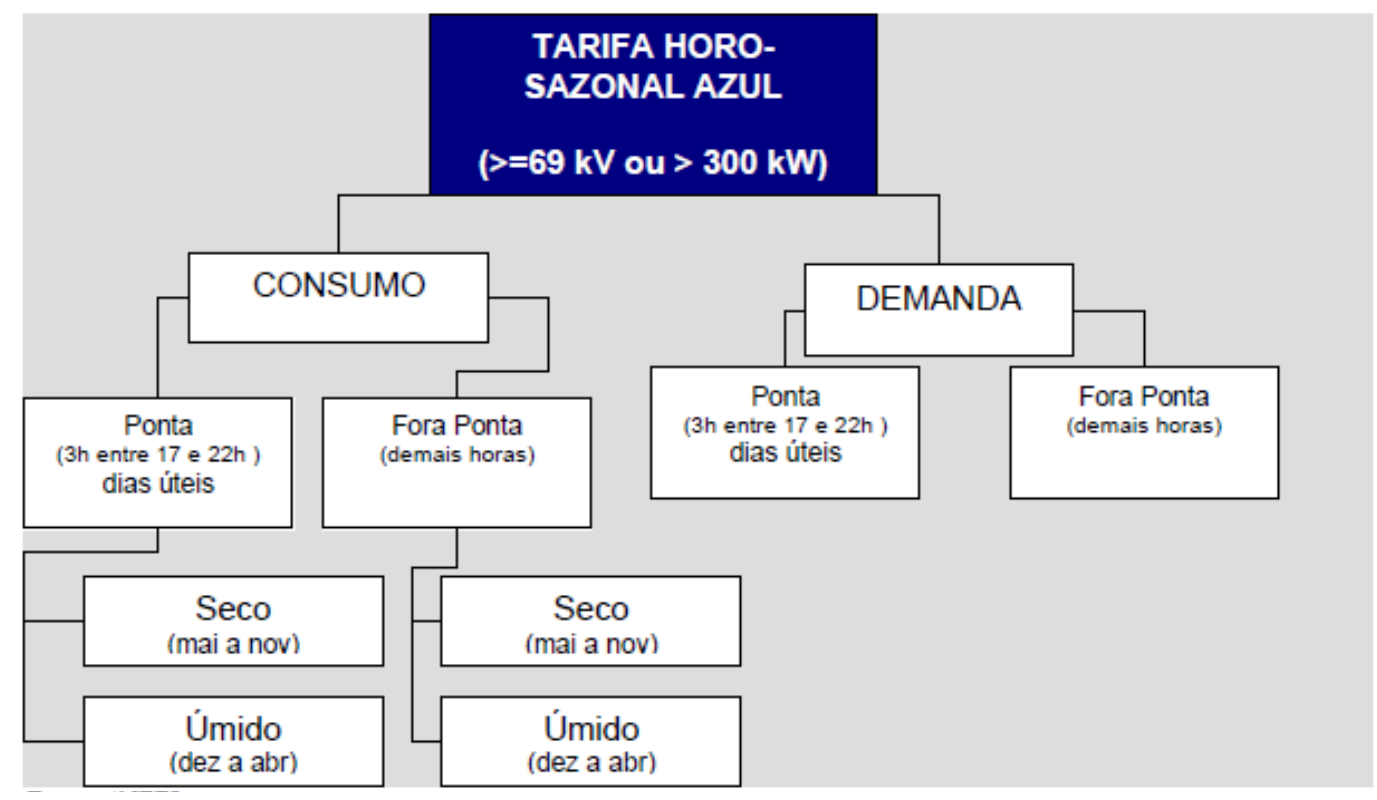

Figura 5.4 Tarifa Horo-Sazonal Azul

Fonte: ANEEL, apud Aguiar, 2008 
A tarifa horo-sazonal verde é a modalidade de fornecimento estruturada para aplicação de tarifas diferenciadas de consumo de energia elétrica, de acordo com as horas de utilização do dia e dos períodos do ano, e de uma única tarifa de demanda de potência, conforme se observa na Figura 5.5.

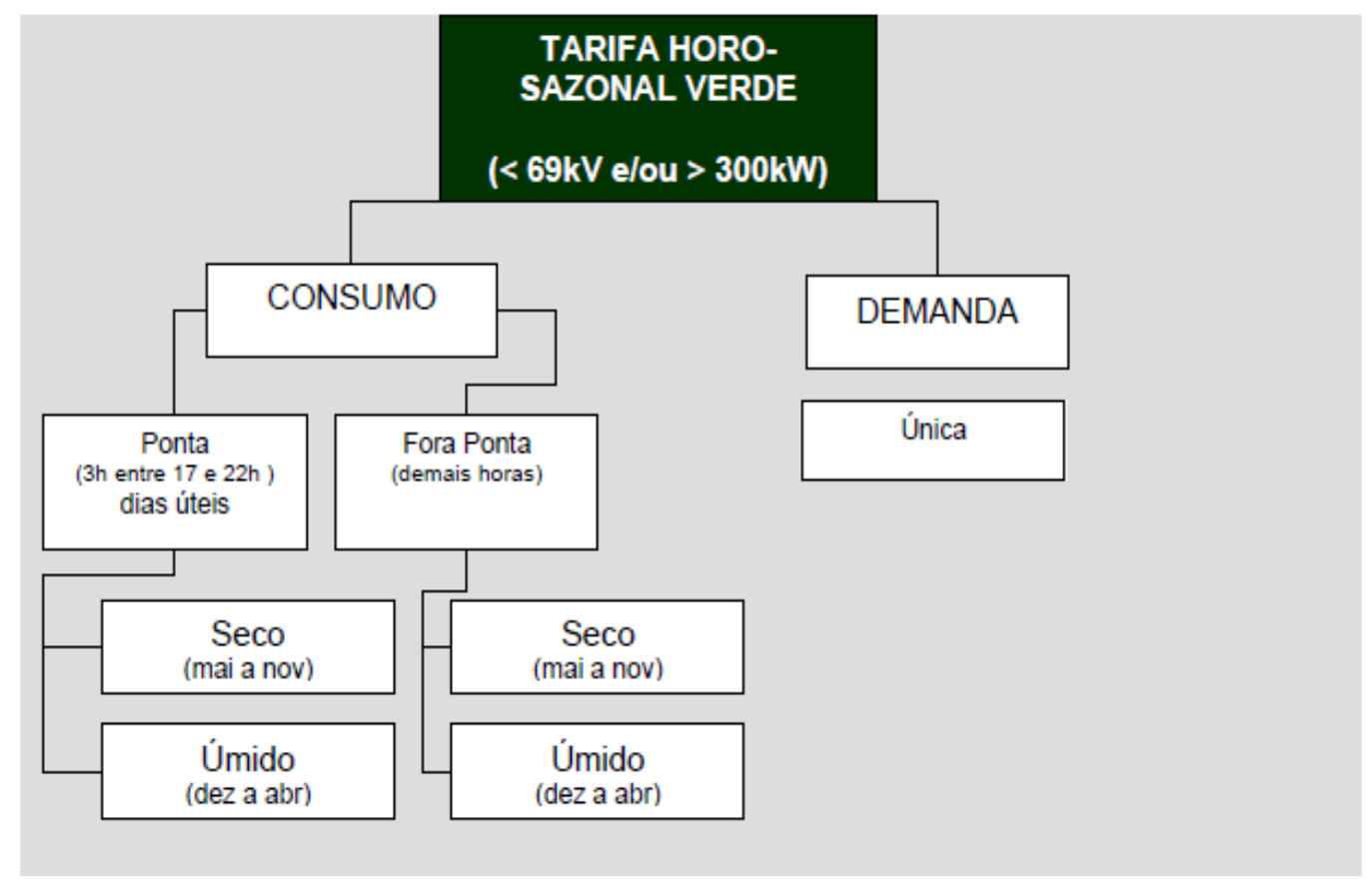

\section{Figura 5.5 - Tarifa Horo-Sazonal Verde}

Fonte: ANEEL, apud Aguiar, 2008

Para as unidades consumidoras atendidas pelo sistema elétrico interligado com tensão de fornecimento inferior a $69 \mathrm{kV}$ e demanda contratada igual ou superior a $300 \mathrm{~kW}$, é obrigatório o enquadramento tarifário na estrutura horo-sazonal azul ou verde, por opção do consumidor.

A composição das tarifas está a cargo da ANEEL, devendo ser fixada de forma a estabelecer uma receita capaz de garantir o equilíbrio econômico-financeiro da concessão. A receita da concessionária de distribuição se compõe de suas parcelas, conforme demonstrado na Tabela 5.1. 
Tabela 5.1. Composição da Receita Requerida

\begin{tabular}{|c|c|}
\hline \multicolumn{2}{|c|}{ COMPOSIÇÃO DA RECEITA REQUERIDA } \\
\hline $\begin{array}{c}\text { PARCELA A } \\
\text { (custos não gerenciáveis) } \\
\end{array}$ & $\begin{array}{c}\text { PARCELA B } \\
\text { (custos gerenciáveis) } \\
\end{array}$ \\
\hline Encargos Setoriais & Despesas de Operação e Manutenção \\
\hline Cotas de Reserva Global de Reversão - RGR & Pessoal \\
\hline Cotas da Conta de Cons. de Combustível-CCC & Material \\
\hline $\begin{array}{l}\text { Taxa de Fiscalização de Serviços de Energia } \\
\text { Elétrica - TFSEE }\end{array}$ & Serviços de Terceiros \\
\hline Rateio de Custos do PROINFA & Despesas Gerais e Outras \\
\hline \multicolumn{2}{|l|}{ Conta de Desenvolvimento Energético - CDE } \\
\hline & Despesas de Capital \\
\hline Encargos de Transmissão & Cotas de Depreciação \\
\hline $\begin{array}{l}\text { Uso das Instalações da Rede Básica de } \\
\text { Transmissão de Energia Elétrica }\end{array}$ & Remuneração do Capital \\
\hline \multicolumn{2}{|l|}{ Uso das Instalações de Conexão } \\
\hline \multicolumn{2}{|l|}{ Uso das Instalações de Distribuição } \\
\hline $\begin{array}{l}\text { Transporte de Energia Elétrica Proveniente de } \\
\text { Itaipu }\end{array}$ & Outros \\
\hline \multirow{2}{*}{ Operador Nacional do Sistema } & P\&D e Eficiência Energética \\
\hline & PIS/CONFINS \\
\hline \multicolumn{2}{|l|}{ Compra de Energia Elétrica para Revenda } \\
\hline \multicolumn{2}{|l|}{ Contratos Iniciais } \\
\hline \multicolumn{2}{|l|}{ Energia de Itaipu } \\
\hline Contratos Bilaterais de Longo Prazo ou Leilões & \\
\hline
\end{tabular}

Fonte: Cadernos Temáticos ANEEL - Tarifas de Fornecimento de Energia Elétrica, 2005

Os custos são considerados como não gerenciáveis, basicamente os encargos, quando não existem, do lado exclusivo da concessionária, ações que possam controlar os valores envolvidos em cada conta, já os custos gerenciáveis, são aqueles que a concessionária tem total capacidade de administrá-lo diretamente dentro de um valor estabelecido previamente, por exemplo, a massa salarial.

Na Tabela 5.2 apresenta-se a participação dos Itens da Parcela A e B na receita requerida das sete maiores distribuidoras. Estes dados refletem a revisão tarifária, periódica ocorrida em 2003.

Os encargos setoriais que compõe a parcela A estão apresentados na Figura 5.6 que demonstra a evolução destes a partir de 1957. 
Tabela 5.2. - Participação dos Itens da Parcela A e B na Receita Requerida das Sete Maiores Distribuidoras

\begin{tabular}{|l|c|}
\hline Parcela A & $\mathbf{6 1 , 5 \%}$ \\
\hline Energia Comprada & $44,7 \%$ \\
\hline Encargos Setorias & $8,2 \%$ \\
\hline Transmissão & $8,6 \%$ \\
\hline Parcela B & $\mathbf{3 8 , 5 \%}$ \\
\hline Custos Operacionais & $13,5 \%$ \\
\hline Remuneração do Capital & $11,9 \%$ \\
\hline Depreciação & $\mathbf{7 , 2} \%$ \\
\hline Inadimplência & $0,4 \%$ \\
\hline Tributos (PIS, CONFINS e P\&D) & $5,6 \%$ \\
\hline Total (A + B) & $\mathbf{1 0 0 , 0 \%}$ \\
\hline
\end{tabular}

Fonte: Amaral Filho, 2007

\section{Encargos setoriais}

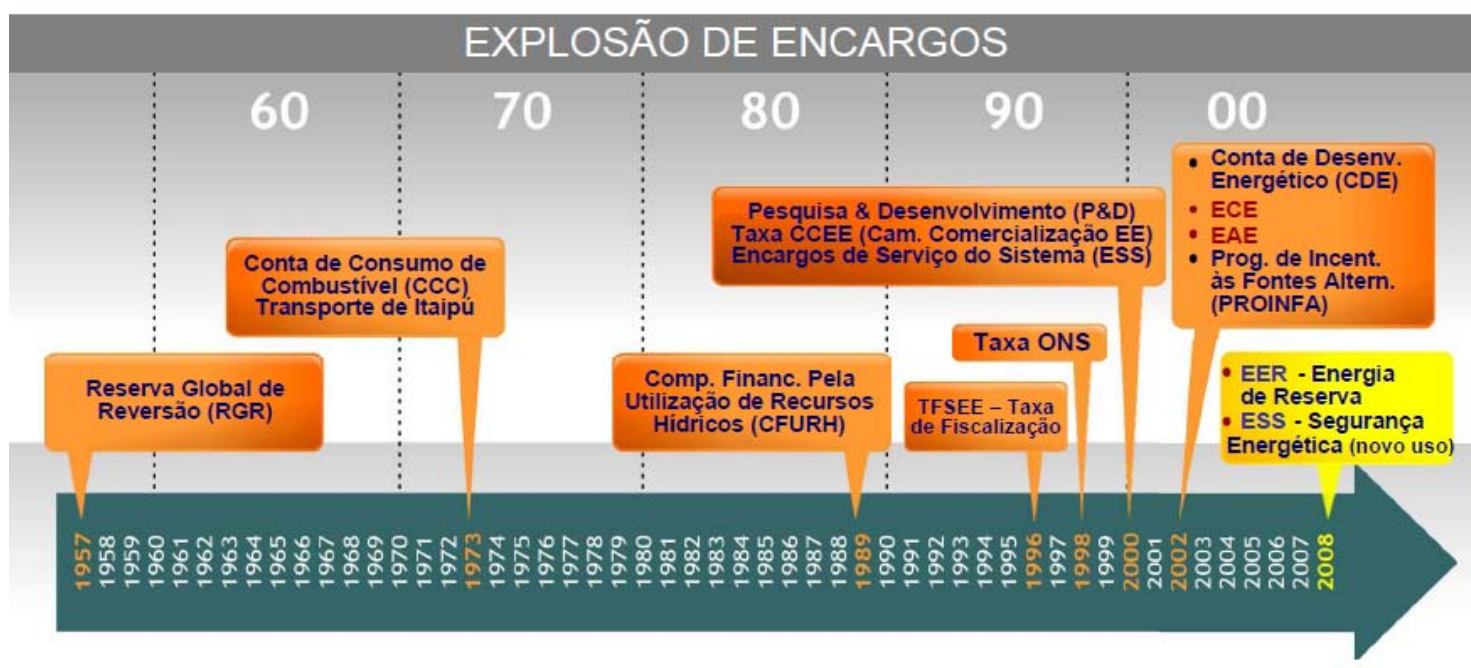

ECE e EAE: descontinuados

- ESS: Em 2008 o custo está em R\$ 5,4/MWh representando um gasto de R\$1,7 bi

Figura 5.6 - Evolução dos Tipos de Encargos Setoriais

Fonte: Eduardo C Spalding, 2008 
Para a atualização das tarifas de fornecimento de energia elétrica são adotados basicamente dois procedimentos. O Reajuste Tarifário Anual tem por objetivo restabelecer, anualmente, o poder de compra da receita obtida pelo concessionário. No reajuste anual as elevações de custo da Parcela A são repassadas às tarifas, mas a parcela $B$ é corrigida pela variação do índice de preços fixado pelo contrato de concessão - IGP-M, menos um percentual denominado ${ }^{19}$ Fator $\mathrm{X}$.

Já a Revisão Tarifária Periódica tem como principal objetivo analisar, após um período previamente definido no contrato de concessão, geralmente de quatro anos, o equilíbrio econômico-financeiro da concessão.

Também pode ocorrer a Revisão Tarifária Extraordinária (RTE) por meio da qual a ANEEL poderá, por solicitação da empresa de distribuição e quando devidamente comprovada, proceder a revisão das tarifas visando manter o equilíbrio econômico-financeiro do contrato.

Em 31 de dezembro de 2002 foi publicado o Decreto $n^{\circ} 4.562$, alterado pelo de $\mathrm{n}^{\circ} 4.667$ de 4 de abril de 2003, que estabeleceu normas que disciplinam o realinhamento gradual das tarifas ao consumidor final, de forma que até 2007 todos os consumidores pagassem o mesmo valor pela energia adquirida tarifa de energia (TE), e valores diferenciados pelos encargos de uso do sistema de transmissão e distribuição - TUSD + TUST, que refletissem a proporção com que eles utilizam os referidos sistemas. O processo de realinhamento iniciado em 2003 e finalizado em 2007 objetivou eliminar os subsídios cruzados, ou seja, custos maiores nas tarifas de energia elétrica que atendiam os consumidores enquadrados na classe de baixa tensão em relação aos custos das tarifas para os atendidos em alta tensão.

A Tabela 5.3 apresenta a variação anual das tarifas médias de energia elétrica por classe de consumo no período de 1998 a 2006. Nota-se que a partir de 2003 os reajustes praticados aos setores residencial e industrial se distanciam.

\footnotetext{
19 Fator X - Fator que atua como instrumento de repartição dos ganhos de eficiência da concessionária com seus consumidores. Previsto nos contratos de concessão assinados entre as empresas prestadoras do serviço público de energia elétrica e a Aneel, o fator $\mathrm{X}$ é um fator de correção do reajuste tarifário com o objetivo principal de induzir a busca pela melhoria da eficiência econômica de cada empresa.
} 
(Em\%)

\begin{tabular}{lccccccc}
\hline $\begin{array}{l}\text { Classe } \\
\text { consumo }\end{array}$ & $\mathbf{1 9 9 8}$ & $\mathbf{2 0 0 0}$ & $\mathbf{2 0 0 2}$ & $\mathbf{2 0 0 3}$ & $\mathbf{2 0 0 5}$ & $\mathbf{2 0 0 6}$ & $\begin{array}{c}\text { Anotal } \\
\text { Acumulado } \\
\text { (1998-2006) }\end{array}$ \\
\hline Residencial & 5,33 & 14,35 & 16,66 & 14,09 & 7,64 & 1,29 & 146,17 \\
Industrial & 3,53 & 12,55 & 16,54 & 16,80 & 34,91 & 12,28 & 280,30 \\
Comercial & 3,34 & 12,37 & 18,84 & 13,31 & 10,16 & 4,38 & 153,95 \\
$\begin{array}{l}\text { Rural } \\
\text { Poder }\end{array}$ & 2,94 & 13,06 & 16,06 & 20,18 & 8,43 & 5,38 & 162,08 \\
$\begin{array}{l}\text { Público } \\
\text { lluminação }\end{array}$ & 3,46 & 13,75 & 19,96 & 15,88 & 10,07 & 7,08 & 175,65 \\
$\begin{array}{l}\text { Pública } \\
\text { Setor }\end{array}$ & 4,93 & 13,64 & 17,91 & 15,75 & 8,67 & 3,04 & 153,12 \\
$\begin{array}{l}\text { Público } \\
\text { Consumo }\end{array}$ & $-0,74$ & 12,42 & 18,54 & 14,90 & 16,45 & 10,49 & 196,71 \\
$\begin{array}{l}\text { Próprio } \\
\text { T Média }\end{array}$ & 5,37 & $-1,07$ & 11,50 & 20,28 & 97,39 & 3,93 & 327,90 \\
\hline & & 13,19 & 16,41 & 16,85 & 19,93 & 5,98 & 205,29 \\
\hline
\end{tabular}

\section{Tabela 5.3 - Variação Anual das Tarifas Médias de Energia Elétrica (\%)}

Fonte: DIEESE, 2007

Mesmo com um percentual de reajuste para a classe residencial inferior a da industrial, o valor da tarifa média para a classe residencial ainda é mais elevado, conforme se observa na Tabela 5.4.

(Em R\$/MWh)

\begin{tabular}{lccccccc}
\hline $\begin{array}{l}\text { Classe } \\
\text { consumo }\end{array}$ & $\mathbf{1 9 9 7}$ & $\mathbf{1 9 9 9}$ & $\mathbf{2 0 0 1}$ & $\mathbf{2 0 0 2}$ & $\mathbf{2 0 0 4}$ & $\mathbf{2 0 0 5}$ & $\mathbf{2 0 0 6}$ \\
\hline Residencial & 119,80 & 138,93 & 179,78 & 209,74 & 270,49 & 291,15 & 294,91 \\
Industrial & 54,61 & 63,11 & 82,18 & 95,75 & 137,11 & 184,97 & 207,68 \\
Comercial & 107,99 & 121,70 & 156,17 & 185,60 & 238,50 & 262,73 & 274,24 \\
Rural & 67,27 & 75,49 & 97,26 & 112,88 & 154,29 & 167,30 & 176,30 \\
$\begin{array}{l}\text { Poder } \\
\text { Público }\end{array}$ & 106,10 & 119,54 & 153,84 & 184,54 & 248,15 & 273,13 & 292,46 \\
$\begin{array}{l}\text { lluminação } \\
\text { Pública }\end{array}$ & 65,31 & 75,51 & 95,55 & 112,66 & 147,64 & 160,44 & 165,31 \\
$\begin{array}{l}\text { Setor } \\
\text { Público }\end{array}$ & 62,65 & 70,60 & 90,04 & 106,73 & 144,48 & 168,24 & 185,89 \\
$\begin{array}{l}\text { Consumo } \\
\text { Próprio }\end{array}$ & 68,59 & 81,03 & 92,25 & 102,86 & 143,07 & 282,40 & 293,50 \\
T Média & 82,16 & 95,86 & 122,88 & 143,05 & 197,35 & 236,68 & 250,83 \\
\hline
\end{tabular}

Tabela 5.4 - Valor Médio das Tarifas de Energia Elétrica ( $\$$ \$MWh)

Fonte: DIEESE, 2007 
Apesar das críticas dos órgãos de defesa dos consumidores quanto ao valor maior da tarifa de energia para os consumidores residenciais, ela se justifica pela necessidade de elevado investimento para o suprimento em baixa tensão, ou seja, necessidade de subestações abaixadoras, redes e equipamentos para os alimentadores de distribuição, além dos problemas de ocupação do solo em centros urbanos, todos estes enfrentados pelas concessionárias.

A evolução das tarifas para o segmento industrial no período de 2001 a 2007 está demonstrada na Figura 5.7, que evidencia um descompasso com os índices de reajustes oficiais.

\section{Evolução da tarifa de energia}

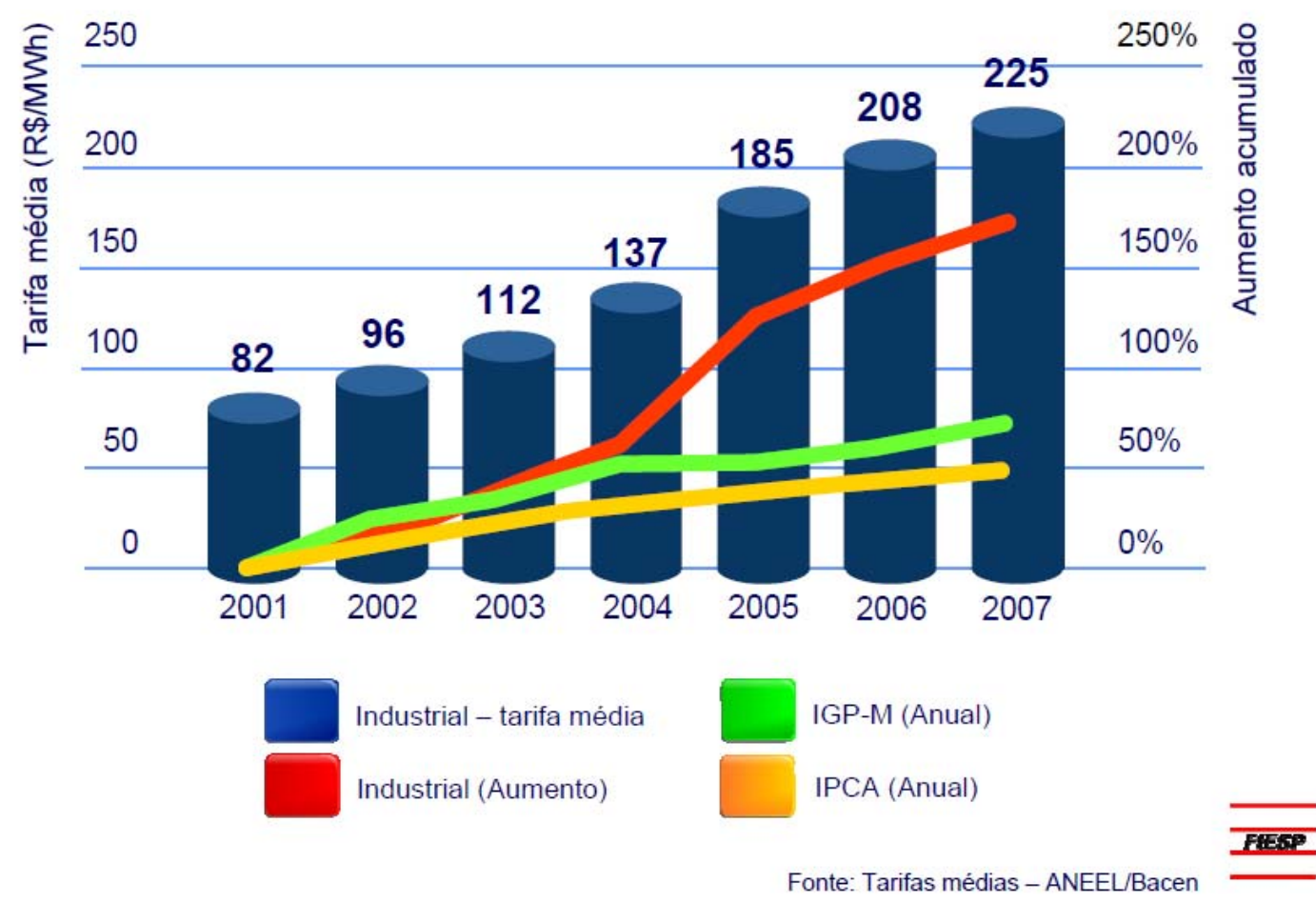

Figura 5.7 - Evolução das Tarifas - Segmento Industrial

Fonte: Eduardo C Spalding, 2008 
A alteração do ambiente regulatório, a segmentação de consumidores entre livres e regulados, a criação dos ambientes de contratação para a compra da energia, a abertura tarifária de modo a se conhecerem os valores das tarifas de energia e os de uso dos sistemas (transmissão e distribuição), são fatos que fizeram com que os consumidores potencialmente livres vissem a necessidade de entender mais profundamente o mercado de energia, de modo a possibilitar uma tomada de decisão sobre permanecer no ambiente regulado ou migrar para o ambiente livre, assumindo nesses dois ambientes os custos e riscos envolvidos.

No mercado livre o consumidor negocia o preço da energia elétrica, o prazo de fornecimento diretamente com o gerador ou o comercializador desta energia e paga à concessionária local, somente as tarifas de uso dos sistemas de transmissão e distribuição, além dos impostos envolvidos.

A tarifa de transporte de energia é formada pelos componentes:

- remuneração dos ativos de distribuição de energia elétrica;

- quota de reintegração dos ativos de distribuição;

- custo de operação e manutenção dos ativos de distribuição

- custo relativo ao uso da rede básica

- custo de conexão com a rede básica

- perdas elétricas no sistema de distribuição

- quota de reserva global de reversão

- contribuição para o Operador Nacional do Sistema Elétrico - ONS

- quota do PROINFA

Com a elevação das tarifas de fornecimento, as indústrias passaram a perceber que, além da necessidade de adoção de medidas de eficiência energética, era necessário o gerenciamento das faturas de energia, analisando vários parâmetros elétricos, ou seja: Consumo Ativo (kWh), Demanda (kW), Fator de Carga (FC), Fator de Potência (FP), Consumo Específico e Preço Médio. Conhecendo estes parâmetros elétricos é possível avaliar a melhor 
forma de contratação de energia no ambiente regulado nas diferentes modalidades tarifárias, conforme anteriormente apresentado.

A busca de uma melhor forma de contratação da energia elétrica é fundamental para manter a competitividade do produto, uma vez que, com a elevação das tarifas do segmento industrial, estes custos tendem a ser repassados para o consumidor final.

A ponderação da melhor alternativa de contratação de energia tanto no ambiente livre como no ambiente regulado, bem como a melhor opção tarifária, são os tópicos abordados no capítulo 6 , tomando-se como caso de estudo uma empresa do ramo alimentício. 


\section{CAPÍTULO 6}

\section{A GESTÃO DE ENERGIA ELÉTRICA NA INDÚSTRIA - SEU SUPRIMENTO E USO EFICIENTE}

A gestão da energia nas indústrias eletrointensivas ${ }^{20}$ e a implementação de ações voltadas para a eficiência energética tornaram-se realidade há alguns anos, pois o custo da energia é representativo no processo produtivo. Já para as indústrias em que o custo da energia não é muito significativo na produção, a prática da gestão da energia e ações de eficiência energética basicamente ganhou importância a partir de 2001, quando estas se viram obrigadas a reduzir o consumo diante do racionamento no fornecimento.

A motivação principal para adoção destas ações foi o receio iminente de uma possível indisponibilidade de energia elétrica no momento seguinte ao racionamento, ou seja, um futuro imprevisível sem um cenário claro sobre a possibilidade de outro racionamento a curto, médio ou longo prazo.

O trabalho de gestão de energia e ações voltadas para a eficiência energética, aqui apresentada se desenvolveu em uma empresa multinacional de grande expressão nacional, composta de 54 unidades consumidoras.

\footnotetext{
${ }^{20}$ São indústrias dos segmentos de alumínio, siderurgia, ferroligas, celulose e petroquímica, nos quais o insumo energia elétrica é o item que mais impacta no custo final do produto.
} 
A empresa apresentou um faturamento em 2008 de $\mathrm{R} \$ 12$ bilhões. É composta de 27 fábricas $^{21}$ e 6 centros de distribuição e é atendida por dez concessionárias e tem forte concentração de suas Fábricas no região sudeste.

A gestão de gastos com energia elétrica nesta empresa iniciou-se em 2002, ainda durante o racionamento de energia elétrica. O objetivo maior naquele momento era mitigar os riscos com o desabastecimento de energia elétrica referente àquele e possíveis outros racionamentos que poderiam ocorrer além de analisar os impactos provocados no negócio.

Entretanto, notou-se que no momento seguinte ao racionamento, havia disponibilidade de energia e com custos mais atrativos, na modalidade livre, ou seja, a proposta inicial de se analisar uma possível falta, acabou por identificar uma oportunidade de redução dos gastos com pagamento de faturas.

Concomitantemente à redução dos gastos com a energia, notou-se oportunidades de redução de consumo através de projetos de eficiência energética nos processos produtivos, o que indiretamente também impactaria em redução dos custos com energia elétrica.

As ações voltadas para a eficiência energética objetivaram avaliar a indústria sob o aspecto tecnológico, de forma a poder verificar novas oportunidades de redução no consumo de energia em seu processo produtivo, conforme exemplo apresentado na seqüência deste capítulo.

Para elaborar e conduzir ações de gestão de gasto e de eficiência energética foi instituído um grupo de trabalho multidisciplinar, com integrantes das áreas jurídica, administrativa, técnica e de suprimento, que coordenou os trabalhos de forma sistêmica e centralizada na sede da indústria, contando com uma consultoria externa atuante na área de energia.

A empresa possuía, naquele momento, cinqüenta e quatro unidades consumidoras, de forma que, foi necessária a criação de representantes locais formado por colaboradores das áreas de produção, administração e técnica

${ }^{21}$ Cada fábrica possui mais do que uma unidade consumidora que funcionam eletricamente independentes, razão pela qual deve ter medição individualizada. 
operacional, que passaram a ser os interlocutores oficiais para garantir a velocidade e a veracidade da informação.

A Gestão Jurídico-Administrativa encarregou-se de conhecer as leis vigentes de forma a poder avaliar os contratos de energia assinados com as distribuidoras envolvidas ${ }^{22}$, e os seus prazos de vigência.

Para visualização e entendimento da situação atual de cada unidade consumidora - UC foi desenvolvida uma planilha preenchida com as informações de cada UC. Os dados refletiam o funcionamento de cada unidade no período de janeiro de 2000 a dezembro de 2002. A seleção deste período foi importante por permitir verificar a situação de cada unidade no período anterior e posterior ao racionamento.

Os dados mais relevantes desta planilha são:

1. Demanda contratada $\times$ demanda medida

2. Consumo de energia elétrica na ponta e fora de ponta

3. Fator de carga

4. Fator de potência

5. Classe de tensão da conexão

6. Data de vencimento do contrato

7. Cláusula de renovação

Quando do recebimento da planilha preenchida pelas UC's, as áreas jurídica e administrativa, com o apoio da consultoria envolvida, puderam identificar as primeiras ações que redundariam em redução de gastos com a fatura mensal, identificando nos contratos as possíveis necessidades de revisão dos enquadramentos tarifários e das demandas contratadas.

O Departamento Jurídico, em conjunto com a área técnica, definiu um novo modelo de contrato a ser aplicado a todas as unidades, tendo sido retirada a cláusula de renovação automática do contrato que constava nos contratos

${ }^{22}$ As 27 unidades da indústria estudada localizam-se nos Estados de São Paulo (SP), Minas Gerais (MG), Bahia (BA), Goiás (GO), Rio de Janeiro (RJ), Rio Grande do Sul (RS) e Espírito Santo (ES), o que envolve diversas concessionárias de distribuição. 
vigentes e era de cinco anos. Assim a contratação passou a ter validade de apenas um ano. Esta medida passou a permitir que a cada ano as unidades consumidoras pudessem avaliar, através de seu grupo de trabalho, (i) a redução de consumo no processo industrial; (II) o novo valor para a demanda a ser contratada para os próximos doze meses ou ainda alterações na vigência do contrato; (iii) a melhor alternativa de tarifa convencional ou horo-sazonal verde ou azul; (iv) a possibilidade de migração para o mercado livre, e (v) a utilização da energia própria advinda de geradores que podem funcionar durante o horário de ponta.

A elaboração de um novo contrato de compra de energia elétrica a cada ano, para cada unidade consumidora, foi e continua sendo a forma de gestão objetiva, que busca contratar apenas o estritamente necessário para a manutenção da capacidade produtiva ao menor preço possível.

As Figuras 6.1 e 6.2 ilustram, respectivamente, um bom exemplo, figura 6.1 e uma ausência total de gerenciamento de demanda contratada na ponta, figura 6.2 .

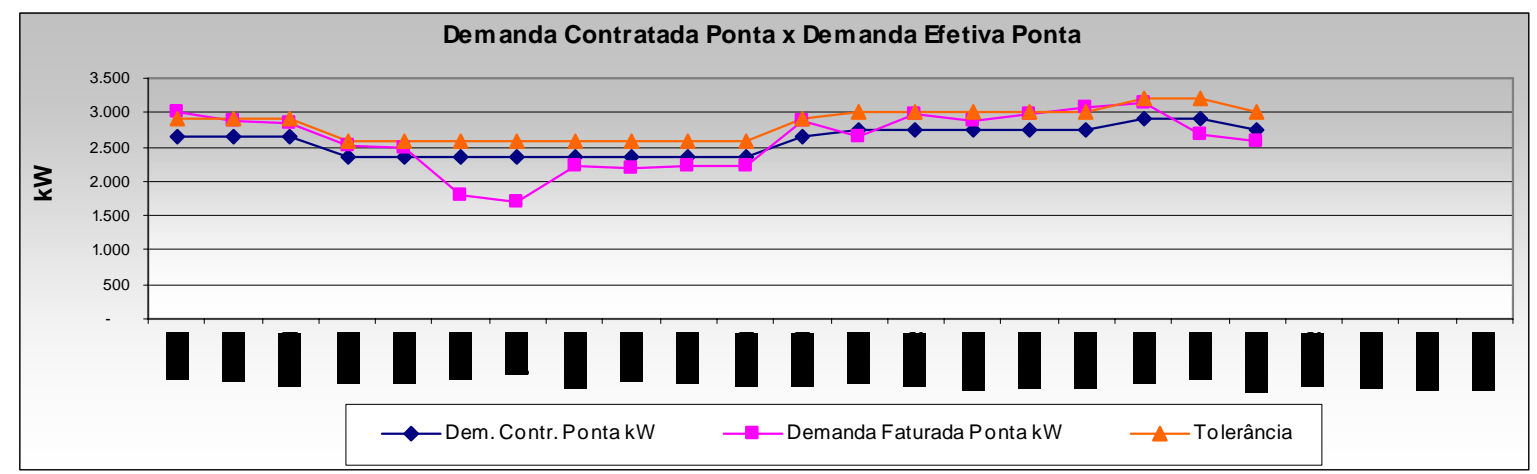

Figura 6.1 - Exemplo de Gerenciamento da Demanda

Fonte: Elaboração própria, utilizando dados de uma Unidade Consumidora. 


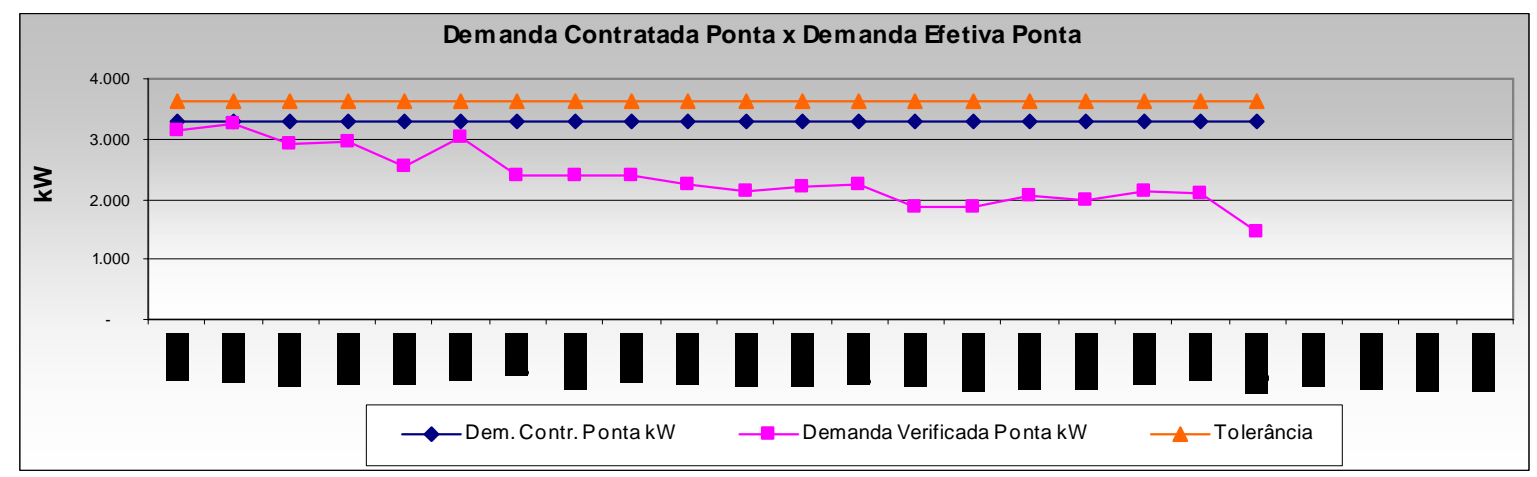

Figura 6.2 - Exemplo de Não Gerenciamento da Demanda

Fonte: Elaboração própria, utilizando dados de uma outra unidade consumidora.

Na figura 6.1, nota-se que a demanda contratada e a verificada andam juntas a cada mês e não existe ultrapassagem da tolerância permitida, que neste caso era de $10 \%$, caso houvesse a ultrapassagem, haveria a necessidade de pagamento de multa na fatura.

Entretanto na figura 6.2, nota-se que a demanda foi contratada muito acima da necessidade real, o que significa pagar e não usar, pois o processo produtivo não requeria o volume contratado, porém pagava-se pelo valor contratado.

A dependência da energia elétrica na indústria é inquestionável e somente a área técnica consegue enxergar com clareza toda a abrangência desta dependência e os impactos que podem ser causados na produção por uma ausência de gestão.

Uma indústria que fabrica produtos assépticos, por exemplo, não pode sofrer com a qualidade da energia, pois a retomada da produção após cada parada do processo produtivo, requer uma reesterilização de toda a linha de envase com soda e ácido, o que significa, além da perda do tempo produtivo, a perda de energia e material de limpeza para a retomada do processo.

A gestão técnica possibilita avaliar os processos produtivos e identificar projetos de eficientização energética, de maneira a poder reduzir a quantidade de energia utilizada por tonelada produzida ( $\mathrm{kWh} / \mathrm{ton})$. 
O kWh/ton é o principal indicador de gestão da área técnica, que deve buscar constantemente a redução deste indicador, estabelecendo metas anuais para este objetivo.

Ações de eficiência energética são imprescindíveis para reduzir este indicador. Estas podem ser comportamentais como, por exemplo, desligar motores/equipamentos não necessários ao processo produtivo, ou como, por exemplo, iluminação natural, utilização de inversores de freqüência em ventiladores e exaustores, ao invés de damper de limitação de fluxo, entre outras ações.

A gestão técnica deve identificar equipamentos e processos mais eficientes, possibilitando que a área de compras possa melhor avaliar o custo/benefício na compra de um equipamento que utilize a energia elétrica para funcionar.

Por exemplo, o custo total com um compressor de ar comprimido, durante dez anos de operação, esta subdividido em três partes: $75 \%$ do valor total, será para pagar a conta de energia elétrica, 10\% com a manutenção e apenas 15\% do gasto total será para aquisição do mesmo. Esta informação é de grande importância para um comprador de compressor de ar comprimido, pois certamente irá ajudá-lo no momento da compra.

O processo produtivo também pode ser melhorado com a gestão técnica. É de extrema importância que a área técnica, junto com a produção avaliem detalhadamente as cargas que entram e saem de operação durante o processo produtivo, de forma a evitar partidas de motores simultâneas, evitando-se picos de demanda registrada desnecessários.

Deve-se priorizar a realização de trabalhos de menor consumo de energia para o horário de ponta, como por exemplo, a limpeza de máquinas e equipamentos. A essência da gestão de compras de energia elétrica está em buscar o menor custo a ser pago pela energia requerida por um determinado período préestabelecido. Para tanto, é necessário acompanhar os preços da energia elétrica praticados pelas concessionárias no mercado regulado, as datas de 
reajustes e a expectativa dos próximos reajustes para poder comparar com os preços praticados no mercado livre e ainda no mercado de curto prazo $\left(s p o t^{23}\right)$. A experiência na gestão de gasto com energia elétrica na indústria estudada, apresenta quatro temas a serem abordados:

1. A instalação de uma nova planta industrial e a contratação da energia elétrica

2. Gestão dos gastos com energia elétrica em uma unidade já existente

3. Ações de eficiência energética

4. Resultados obtidos em 2005 através das ações de Eficiência Energética e redução de gastos.

${ }^{23}$ A CCEE contabiliza as diferenças entre os valores produzidos ou consumidos e os valores contratados. As diferenças positivas ou negativas são liquidadas no Mercado de Curto Prazo e valoradas ao PLD (Preço de Liquidação das Diferenças), determinado semanalmente para cada patamar de carga e para cada submercado, tendo como base o custo marginal de operação do sistema. 


\subsection{A instalação elou ampliação de uma planta industrial e a contratação de energia elétrica}

Para a instalação de uma nova planta industrial ou ampliação de uma já existente, uma série de estudos econômicos são realizados. Dentre estes, merece destaque o custo final do produto, item de relevância significativa que definirá a viabilidade econômica do projeto.

$\mathrm{Na}$ lista de indicadores e de premissas estabelecidas para o sucesso do empreendimento, não devem faltar avaliações da disponibilidade de energia e de sua qualidade, dentro de uma mentalidade de sustentabilidade energética da região onde a nova planta industrial será instalada.

Esta avaliação foi realizada pela empresa estudada neste trabalho, que inaugurou em novembro de 2008 mais uma planta de processamento de leite fresco no Rio Grande do Sul.

A região escolhida deu-se em função da atratividade do negócio identificado pela indústria, mas a rede elétrica que atende ao município não suportaria o incremento de demanda necessário para atender à nova fábrica, sem que houvesse um investimento significativo que pudesse reforçar a rede em um trecho de $40 \mathrm{~km}$. Sem este investimento não haveria energia disponível durante o horário de ponta.

Como o terreno ainda não havia sido escolhido, os representantes da indústria procuraram a concessionária local, neste caso a RGE - Rio Grande Energia, empresa pertencente ao grupo CPFL Energia, objetivando identificar uma forma de se obter a energia necessária para a operação da fábrica.

Após várias reuniões e análises de viabilidade, identificou-se que a utilização de geradores movidos a diesel durante o horário de ponta seria a melhor alternativa, pois o custo da energia gerada alternativamente com sistemas auxiliares seria menor que o custo da energia elétrica, comprada no ambiente regulado. 
Para o horário fora ponta optou-se pela utilização da energia em média tensão - classe A4, que era disponível na modalidade cliente cativo, e desta forma evitou-se investimentos de reforço na linha de transmissão existente.

Com esta ação, acordada previamente, definiu-se o local da compra do terreno. $\mathrm{Na}$ seqüência celebrou-se um contrato de fornecimento de energia elétrica com a RGE, na modalidade THS Azul, com demanda contratada na ponta igual a 30 kW e demanda contratada fora de ponta igual a $900 \mathrm{~kW}$.

Paralelamente, assinou-se outro contrato com a CPFL Energia para o fornecimento de dois geradores de energia elétrica, movidos a diesel, com capacidade total de $700 \mathrm{kVA}$, energia suficiente para a indústria operar no horário de ponta.

Como a demanda contratada fora de ponta era de $900 \mathrm{~kW}$, a possibilidade de uma alimentação em alta tensão foi descartada, pois neste caso dever-se-ia incluir no investimento total do projeto, adicionalmente, uma subestação abaixadora de alta tensão que impactaria nos investimentos. Apesar da qualidade de suprimento em alta tensão ser melhor e os custos envolvidos tanto para a energia, quanto para a da demanda, serem mais baixos, o retorno do capital investido para este fim seria de 10 anos, prazo incompatível com as premissas estabelecidas para o protejo como um todo.

A construção das instalações para os geradores e o fornecimento dos mesmos foram financiados pela concessionária, e pagos em parcelas mensais, com a economia calculada entre o valor da energia valorada pelas tarifas de ponta e aquelas efetivamente pagas na opção de geração diesel para operar, manter e depreciar o investimento.

O contrato foi assinado em regime de BOT - Built Operation and Transfer, ou seja, depois de efetivado o pagamento relativo a todo o investimento, incluso a remuneração do capital envolvido, o ativo é transferido para o usuário, sem custo residual.

O estudo de viabilidade considerou a análise da disponibilidade de energia elétrica previamente, evitando-se com isto o insucesso do projeto como um todo. 
O envolvimento da concessionária em análises de viabilidade será sempre importante, pois o órgão regulador estabelece que os padrões e normas técnicas das distribuidoras devem ser atendidos em novos projetos e/ou ampliações. Parte dos investimentos nessas obras é de responsabilidade da Distribuidora, sendo a participação deste custeio feita conforme estabelecido na Resolução 250/2007 da Aneel ${ }^{24}$.

Avaliada e definida previamente a forma de contratação da energia elétrica na planta e considerados os investimentos iniciais, deve-se então prever o custeio da fatura, estimando o seu impacto nos resultados do investimento.

O indicador adotado é sempre o custo estimado total da energia elétrica consumida, somado ao custo total da demanda contratada, (baseado no plano de produção estabelecido para o estudo de viabilidade), dividindo-se esta soma pela energia efetivamente consumida. Este indicador tem como unidade $(\mathrm{R} \$ / \mathrm{kWh})$.

Os valores expressos em reais praticados pela concessionária para a energia elétrica e para a demanda na ponta e fora ponta estão disponíveis na Aneel para consulta e também nas próprias concessionárias. Desta forma, cabe avaliar as previsões futuras de variação do índice de reajuste da tarifa de energia elétrica. Na Figura 6.3 pode-se observar que o IGP-M - Índice Geral de Preços - Mercado vem evoluindo acima de outros indicadores econômicos, como IPC - Índice de Preço ao Consumidor e o IPCA - Índice de Preço ao Consumidor Amplo.

\footnotetext{
${ }^{24}$ Resolução Normativa ANEEL 250/2007 - Estabelece os procedimentos para fixação do encargo de responsabilidade da concessionária ou permissionária de distribuição de energia elétrica, bem como para o cálculo da participação financeira do consumidor, referente ao custo necessário para atendimento de pedidos de prestação de serviço público de energia elétrica.
} 


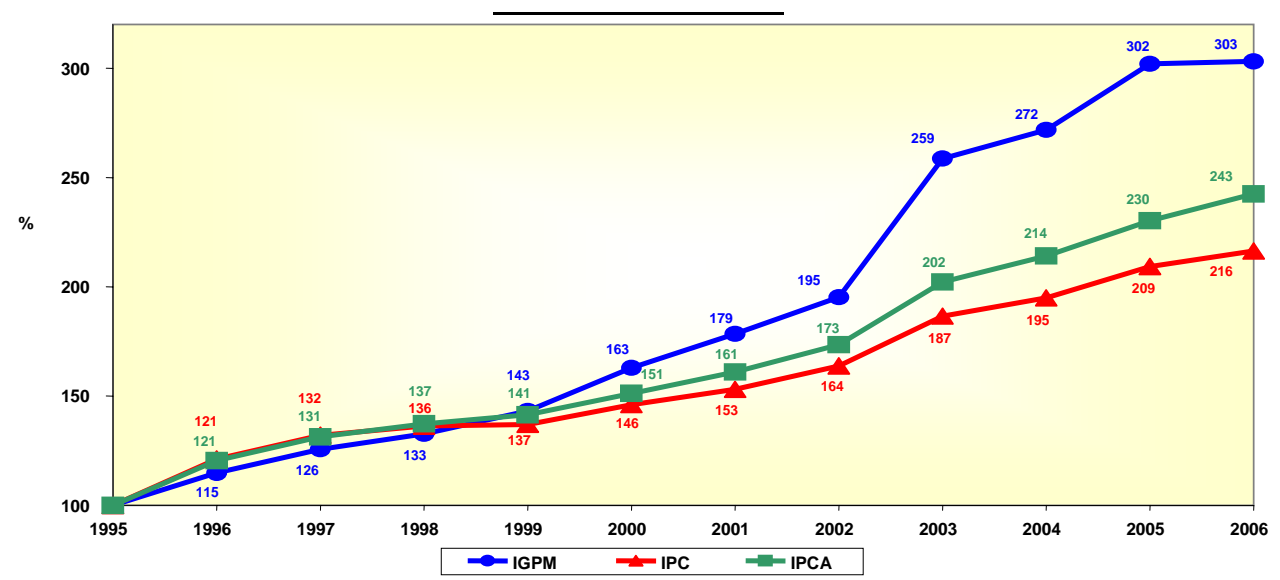

Figura 6.3 - Comparativo de Indicadores Econômicos no Brasil

Fonte: Dieese

Avaliando a Figura 6.3 nota-se que o descolamento acentuado entre os índices ocorreu em 1999 com a desvalorização do real, ampliando-se a cada ano, sendo que a após 2002 o descolamento foi ainda mais sensível.

As Figuras 6.4 e 6.5 demonstram, respectivamente, a variação percentual dos preços da energia elétrica na modalidade cliente regulado, praticados pela Cemig, que atende o estado de Minas Gerais e pela Light, que atende parte do estado do Rio de Janeiro.

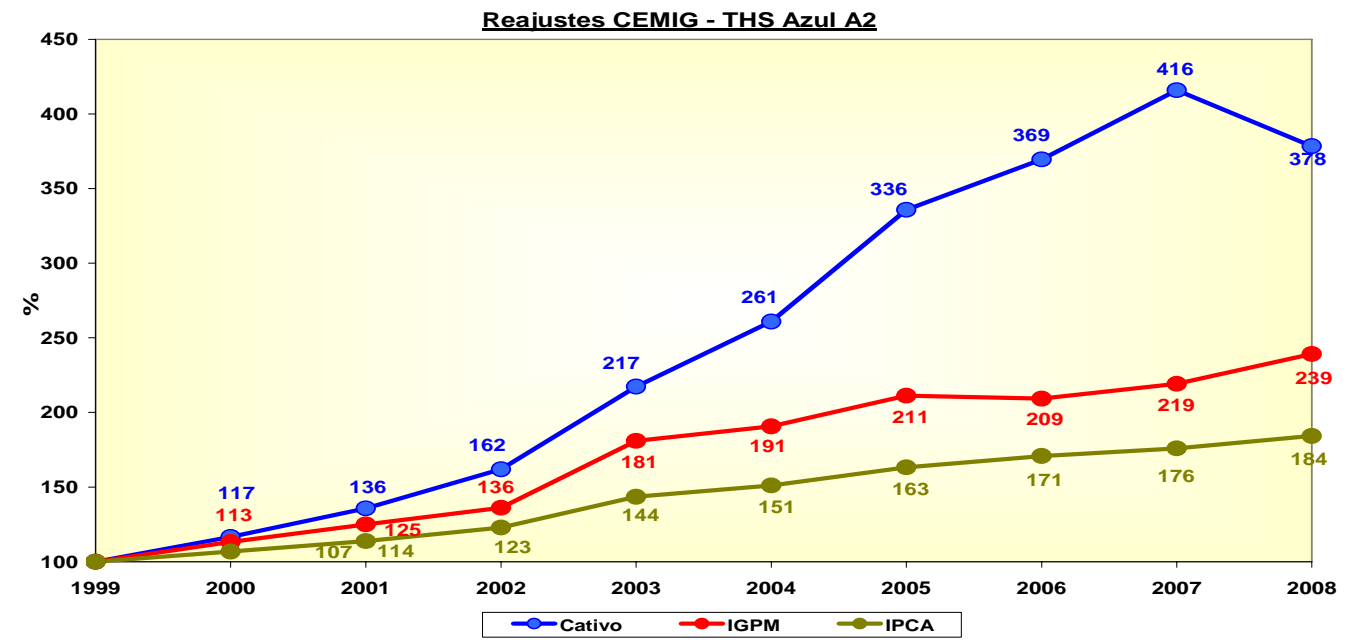

Figura 6.4 - Evolução das Tarifas em Percentual - Cemig -THS Azul

Fonte: Elaboração própria, 2008 


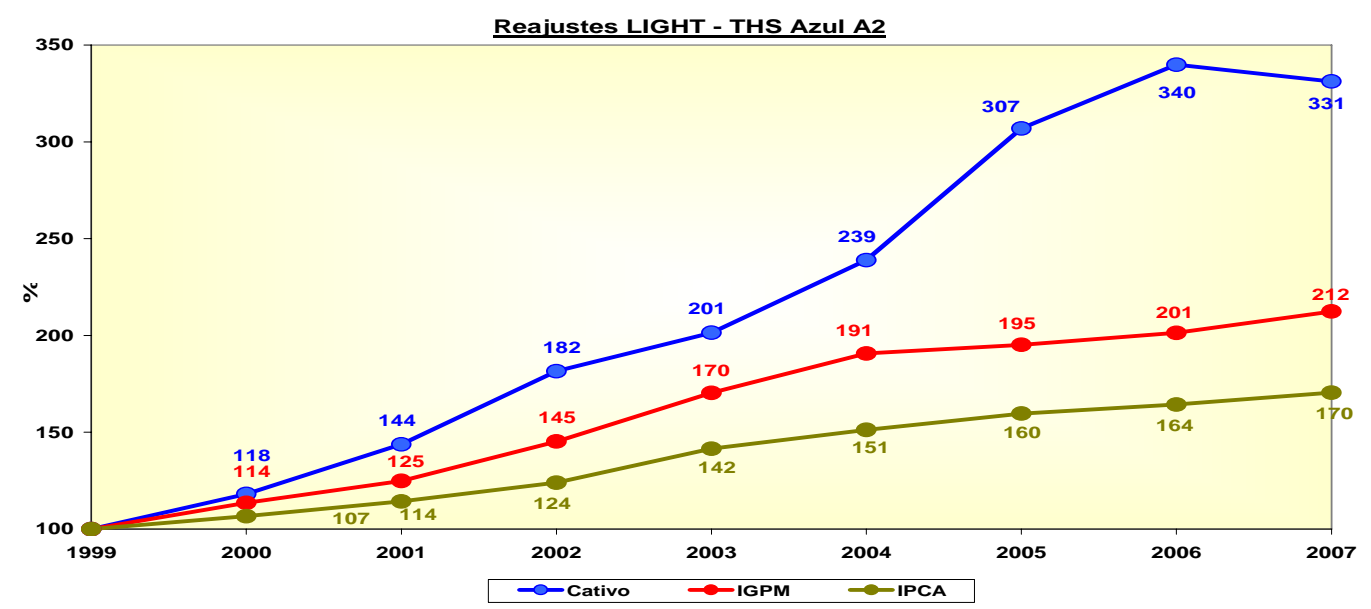

Figura 6.5 - Evolução das Tarifas em Percentual - Light -THS Azul

Fonte: Elaboração própria, 2007

Nas Figuras 6.4 e 6.5 nota-se que a variação dos custos praticados pelas duas concessionárias, para a modalidade cliente cativo, conectados em redes de alta tensão classe A2, considerando um fator de carga de 0,8, foi ainda maior que a variação do IGPM. Isto decorre do fato das tarifas serem fortemente influenciadas pelas variações dos custos não gerenciáveis, conforme anteriormente abordado.

A análise e definição da fonte e da modalidade de contratação de energia elétrica que será a escolhida em um determinado projeto, sendo ele de uma nova instalação ou de uma ampliação são fundamentais para garantir a competitividade do produto. Deve-se sempre avaliar as modalidades de contratação de energia elétrica no mercado regulado ou no mercado livre. $\mathrm{Na}$ modalidade livre deve-se avaliar a localização física da fonte de geração visando identificar restrições operacionais na integração do gerador ou carga nos submercados, que apresentam preços diferenciados.

Finalizadas estas avaliações é necessário definir o fator de carga da planta ${ }^{25}$. Para tanto, a regra é a de avaliar a ocupação de planta durante os anos

25 O fator de carga: Razão entre a demanda média e a demanda máxima da unidade consumidora, ocorrida no mesmo intervalo de tempo especificado (Resolução Aneel 456/2000, art. $2^{\circ}, \mathrm{XVIII)}$ 
previstos no estudo e definir como serão divididos os turnos de produção. Com isso pode-se estimar, de uma maneira bastante assertiva, o valor do fator de carga, definindo o custo estimado $\mathrm{R} \$ / \mathrm{kWh}$ mês a mês. Para o cálculo do fator de carga utilizam-se as seguintes expressões:

Para a tarifa convencional

$\mathrm{Fc}=$ Consumo Mensal $(\mathrm{kWh}) /[$ Demanda $(\mathrm{kW}) \times 730 \mathrm{hs}]$

Para tarifa horo-sazonal azul

Fcp $=$ Consumo ponta $/[\mathrm{Dp} \times 66 \mathrm{hs}]$

Para tarifa horo-sazonal verde

Fcfp $=$ Consumo FP $/[$ Dfp $\times 664$ hs $]$

onde:

$\mathrm{Fc}=$ Fator de Carga

Fcp $=$ Fator de Carga Ponta

Fcfp = Fator de Carga Fora da Ponta

Dp $=$ Demanda de Ponta

Com o custo em $\mathrm{R} \$ / \mathrm{kWh}$ estimado previamente mês a mês, chega-se ao segundo e mais importante indicador, que é o custo $\mathrm{R} \$$ /unidade de produto fabricada. Com isso pode-se efetivamente avaliar o impacto do custo da energia elétrica no custo final do produto e se esse impacto é significativo. Enfim, pode-se concluir se o negócio é viável ou não.

O envolvimento de especialistas da área para aconselhar e fornecer opções de contratação de energia elétrica ou até mesmo soluções alternativas, como a autoprodução, será de fundamental importância para o sucesso do investimento e/ou ampliação que envolva contratação de energia elétrica para consumo industrial. Enfim, a oportunidade de uma boa contratação de energia elétrica começa neste estudo. 


\subsection{A Gestão dos gastos com energia elétrica na indústria}

A gestão dos gastos com energia elétrica na indústria inicia-se com a análise dos gastos efetivos apontados na fatura mensal de energia elétrica, e com a analise do contrato vigente, sendo necessário avaliar tanto os gastos mensais, quanto identificar as oportunidades de redução coerentes com as condições estabelecidas.

Para o caso da demanda contratada na ponta e fora ponta, os valores apresentados nas faturas mensais devem, preferencialmente, estar dentro da faixa de tolerância de uso permitido evitando o pagamento de multa, conforme estabelecido na Resolução Aneel 456/2000²6.

Como um dos objetivos deste trabalho é apresentar um plano de gestão para indústria multifábricas, a partir do momento que uma nova unidade consumidora entra em operação, a gestão da sua fatura passa a ser analisada mensalmente junto com as demais. Para tanto, informações mensais que constam na fatura de energia devem chegar ao time de gestores de maneira organizada e padronizada, através, por exemplo, de planilhas como as das Tabelas 6.1 e 6.2, ou mesmo através de sistemas automáticos de medição "online", existentes no mercado.

\footnotetext{
${ }^{26}$ Art. 56. Sobre a parcela de demanda medida, que superar a respectiva demanda contratada, será aplicada a tarifa de ultrapassagem, caso aquela parcela seja superior aos limites de tolerância a seguir fixados:

I - 5\% (cinco por cento) para unidade consumidora atendida em tensão de fornecimento igual ou superior a $69 \mathrm{kV}$; e

II - 10\% (dez por cento) para unidade consumidora atendida em tensão de fornecimento inferior a $69 \mathrm{kV}$;

$\S 1^{\circ}$ - A tarifa de ultrapassagem aplicável a unidade consumidora faturada na estrutura tarifária convencional, será correspondente a 3 (três) vezes o valor da tarifa normal de fornecimento.
} 
Tabela 6.1 - Informações Referentes à Demanda de Energia na Indústria

\begin{tabular}{|c|c|c|c|c|c|c|c|c|c|c|c|c|c|c|}
\hline \multirow[t]{2}{*}{ MES } & \multicolumn{7}{|c|}{ DEMANDA NA PONTA } & \multicolumn{7}{|c|}{ DEMANDA FORA DE PONTA } \\
\hline & $\begin{array}{c}\text { Dem. } \\
\text { Contr. } \\
\text { Ponta } \\
\text { ky }\end{array}$ & $\begin{array}{c}\text { Deman. } \\
\text { Tolerân- } \\
\text { cia } \\
k \checkmark\end{array}$ & $\begin{array}{c}\text { Demanda } \\
\text { Yerificada } \\
\text { Ponta } \\
\text { k }\end{array}$ & $\begin{array}{c}\text { Demanda } \\
\text { Uitrapas- } \\
\text { sagem } \\
k \checkmark\end{array}$ & \begin{tabular}{|c|} 
Multa \\
Uitrapas- \\
sagem \\
Rs
\end{tabular} & \begin{tabular}{|c|}
$\begin{array}{c}\text { Valor } \\
\text { Unitário } \\
\text { Demanda } \\
\text { Ponta } \\
\text { Rः }\end{array}$ \\
\end{tabular} & \begin{tabular}{|c|} 
Yalor Pago \\
Demanda \\
Ponta \\
Rs
\end{tabular} & $\begin{array}{c}\text { Dem. } \\
\text { Contr. } \\
k \mathbf{v}\end{array}$ & $\begin{array}{c}\text { Deman. } \\
\text { Tolerân- } \\
\text { cia } \\
k \checkmark\end{array}$ & $\begin{array}{c}\text { Demanda } \\
\text { Yerificada } \\
\text { F. Ponta } \\
\text { kV }\end{array}$ & $\begin{array}{c}\text { Demanda } \\
\text { Uitrapas- } \\
\text { sagem } \\
\mathrm{k}\end{array}$ & $\begin{array}{c}\text { Multa } \\
\text { Uitrapas- } \\
\text { sagem } \\
\text { Rs }\end{array}$ & \begin{tabular}{|c|} 
Valor \\
Unitário \\
Demandaa \\
F. Ponta \\
R\$ \\
\end{tabular} & $\begin{array}{c}\text { Yalor Pago } \\
\text { Demanda } \\
\text { F. Ponta } \\
\text { R\$ }\end{array}$ \\
\hline $\operatorname{jan} / 01$ & 2.650 & 2.915 & $3.024,00$ & 374,00 & $18.355,92$ & 16,36 & $61.709,92$ & 3.200 & 3.520 & $3.093,00$ & 0,00 & 0,00 & 5,45 & $16.856,85$ \\
\hline feviol & 2.650 & 2.915 & $2.967,00$ & 317,00 & $15.558,36$ & 16,36 & $58.912,36$ & 3.200 & 3.520 & $3.128,00$ & 0,00 & 0,00 & 5,45 & $17.047,60$ \\
\hline mario1 & 2.650 & 2.915 & $2.948,00$ & 298,00 & $14.625,84$ & 16,36 & $57.979,84$ & 3.200 & 3.520 & $3.087,00$ & 0,00 & 0,00 & 5,45 & $16.824,15$ \\
\hline abriol & 2.350 & 2.585 & $2.615,00$ & 265,00 & $13.006,20$ & 16,36 & $51.452,20$ & 2.900 & 3.190 & $3.082,00$ & 0,00 & 0,00 & 6,22 & $19.170,04$ \\
\hline mais01 & 2.350 & 2.585 & $2.499,00$ & 0,00 & \begin{tabular}{|c|}
0,00 \\
\end{tabular} & 18,66 & $46.631,34$ & 2.900 & 3.190 & $2.966,00$ & 0,00 & 0,00 & 6,37 & $18.893,42$ \\
\hline juni01 & 2.350 & 2.585 & $2.504,00$ & 0,00 & 0,00 & 19,12 & $47.876,48$ & 2.900 & 3.190 & $2.989,00$ & 0,00 & 0,00 & 6,37 & $19.039,93$ \\
\hline juliol & 2.350 & 2.585 & $2.489,00$ & 0,00 & 0,00 & 19,12 & $47.589,68$ & 2.900 & 3.190 & $2.874,00$ & 0,00 & 0,00 & 6,37 & $18.307,38$ \\
\hline ago/01 & 2.350 & 2.585 & $2.490,00$ & 0,00 & 0,00 & 19,12 & $47.608,80$ & 2.900 & 3.190 & $2.961,00$ & 0,00 & 0,00 & 6,37 & $18.861,57$ \\
\hline set/01 & 2.350 & 2.585 & $2.525,00$ & 0,00 & 0,00 & 19,12 & $48.278,00$ & 2.900 & 3.190 & $3.001,00$ & 0,00 & 0,00 & 6,37 & $19.116,37$ \\
\hline out/01 & 2.350 & 2.585 & $2.565,00$ & 0,00 & 0,00 & 19,12 & $49.042,80$ & 2.900 & 3.190 & $3.151,00$ & 0,00 & 0,00 & 6,37 & $20.071,87$ \\
\hline nowi01 & 2.350 & 2.585 & $2.560,00$ & 0,00 & 0,00 & 19,12 & $48.947,20$ & 3.200 & 3.520 & $3.329,00$ & 0,00 & 0,00 & 6,37 & $21.205,73$ \\
\hline $\operatorname{dez} / 01$ & 2.650 & 2.915 & $2.877,00$ & 0,00 & 0,00 & 19,28 & $55.468,56$ & 3.200 & 3.520 & $3.381,00$ & 0,00 & 0,00 & 6,42 & $21.706,02$ \\
\hline
\end{tabular}

Fonte: Elaboração própria com base nos dados das faturas da indústria estudada

\section{Tabela 6.2 - Informações Referentes ao Consumo de Energia na Indústria}

\begin{tabular}{|c|c|c|c|c|c|c|c|c|c|c|c|c|c|c|c|}
\hline \multirow{3}{*}{ MEs } & \multicolumn{12}{|c|}{ ENERGLA PONTA E FORA DE PONTA } & \multicolumn{3}{|c|}{ GERAL DA CONTA } \\
\hline & \multirow{2}{*}{$\begin{array}{c}\text { Energia } \\
\text { Ponta } \\
\text { kWh }\end{array}$} & \multirow{2}{*}{ 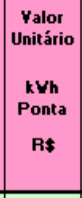 } & \multirow{2}{*}{$\begin{array}{c}\text { Energia } \\
\text { Ponta } \\
\text { R* }\end{array}$} & \multirow{2}{*}{$\begin{array}{c}\text { Multa } \\
\text { Energia } \\
\text { Ponta } \\
\text { Reativa } \\
\text { Rs }\end{array}$} & \multirow{2}{*}{$\begin{array}{l}\text { Energia } \\
\text { F. Ponta } \\
\text { kVh }\end{array}$} & \multirow{2}{*}{$\begin{array}{c}\text { Yalor } \\
\text { Unitário } \\
\text { kVh F. } \\
\text { Ponta } \\
\text { Rs }\end{array}$} & \multirow{2}{*}{$\begin{array}{l}\text { Energia } \\
\text { F. Ponta } \\
\text { Rs }\end{array}$} & \multirow{2}{*}{\begin{tabular}{|c} 
Multa \\
Energia \\
F. Ponta \\
Reativa \\
Rs
\end{tabular}} & \multicolumn{2}{|c|}{$\begin{array}{l}\text { Energia Ponta } \\
\text { Backup Gerador }\end{array}$} & \multirow{2}{*}{ 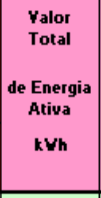 } & \multirow{2}{*}{$\begin{array}{l}\text { Yalor Total } \\
\text { de Energia } \\
\text { Ativa } \\
\text { Rs }\end{array}$} & \multirow{2}{*}{\begin{tabular}{|c} 
MULTA \\
ATRASO \\
R\$
\end{tabular}} & \multirow{2}{*}{$\begin{array}{c}\text { IMPOSTOS } \\
\text { Rs }\end{array}$} & \multirow{2}{*}{$\begin{array}{l}\text { YALOR } \\
\text { TOTAL } \\
\text { SI ICMS } \\
\text { Rs } \\
\end{array}$} \\
\hline & & & & & & & & & kVh & Rs & & & & & \\
\hline jan & 164.420 & 0,0994 & $16.349,92$ & 584,71 & 1.603 .440 & 0,0452 & $72.395,32$ & $1.932,42$ & & & 1.767 .860 & $88.745,24$ & 0,00 & $34.857,79$ & $158.815,02$ \\
\hline fev & 138.783 & 0,0994 & $13.800,58$ & 357,09 & 1.462 .640 & 0,0452 & $66.083,20$ & $1.314,77$ & & & 1.601 .423 & $79.883,78$ & 0,00 & $32.471,68$ & $147.944,96$ \\
\hline $\max$ & 151.384 & 0,0994 & $15.053,62$ & 332,33 & 1.572 .000 & 0,0452 & $70.975,80$ & $1.260,59$ & & & 1.723 .384 & $86.029,42$ & 0,00 & $33.342,97$ & $151.914,16$ \\
\hline $\mathbf{a b r}$ & 125.501 & 0,1225 & $15.374,25$ & 363,59 & 1.321 .760 & 0,0582 & $76.989,88$ & $1.304,76$ & & & \begin{tabular}{|l}
1.447 .261 \\
\end{tabular} & $92.364,13$ & 0,00 & $35.113,42$ & $159.979,53$ \\
\hline mai & 107.093 & 0,1255 & $13.441,24$ & 226,29 & 1.142 .160 & 0,0597 & $68.164,11$ & 740,03 & & & 1.249 .253 & $81.605,35$ & 0,00 & $32.376,36$ & $147.510,69$ \\
\hline jun & 64.200 & 0,1255 & $8.057,74$ & 112,83 & 951.760 & 0,0597 & $56.801,04$ & 343,76 & & & 1.015 .960 & $64.858,78$ & 0,00 & $27.836,20$ & $126.827,77$ \\
\hline jul & 76.726 & 0,1255 & $9.629,88$ & 116,72 & 1.020 .640 & 0,0597 & $60.911,80$ & 353,31 & & & 1.097 .366 & $70.541,68$ & 0,00 & $29.086,62$ & $132.524,11$ \\
\hline ago & 87.453 & 0,1255 & $10.976,23$ & 141,20 & 1.028 .640 & 0,1092 & $112.335,01$ & 453,57 & & & 1.116 .093 & $123.311,24$ & 0,00 & $40.697,56$ & $185.418,41$ \\
\hline set & 92.042 & 0,1255 & $11.552,19$ & 92,12 & 1.119 .200 & 0,0597 & $66.793,86$ & 458,34 & & & 1.211 .242 & $78.346,05$ & 0,00 & $30.989,42$ & $141 \cdot 192,42$ \\
\hline out & 115.830 & 0,1255 & $14.537,82$ & 43,43 & 1.300 .240 & 0,0597 & $77.598,32$ & 510,86 & & & 1.416 .070 & $92.136,14$ & 0,00 & $33.990,79$ & $154.866,60$ \\
\hline nov & 109.058 & 0,1256 & $13.697,87$ & 29,87 & 1.310 .960 & 0,0597 & $78.238,09$ & 458,34 & & & 1.420 .018 & $91.935,96$ & 0,00 & $34.060,18$ & $155.186,12$ \\
\hline dez & 126.767 & 0,1171 & $14.841,75$ & 37,58 & 1.410 .640 & 0,0532 & $74.991,03$ & 637,93 & & & 1.537 .407 & $89.832,78$ & 0,00 & $36.274,47$ & $165.273,44$ \\
\hline
\end{tabular}

Fonte: Elaboração própria com base nos dados das faturas da indústria estudada

Com as informações contidas nas planilhas demonstradas nas Tabelas $6.1 \mathrm{e}$ 6.2 pode-se avaliar mensalmente os gastos relativos à demanda e à energia consumida na ponta e fora da ponta, e com estas informações avaliar se a contratação e o uso estão otimizados.

Observa-se na tabela 6.1, que até o mês de abril daquele ano, havia o pagamento de multas por ultrapassagem de demanda na ponta, quando então, foi ajustado o processo produtivo e através da instalação de um controlador de 
demanda, priorizando as cargas essências e desligando cargas não prioritárias ao longo do processo produtivo, eliminou-se a ocorrência de ultrapassagem da demanda na ponta.

Concomitantemente estabeleceu-se a instalação de capacitores para a correção da multa de reativo que foi decrescendo o valor até ser eliminado totalmente no ano seguinte.

Quando a demanda registrada estiver abaixo da contratada, paga-se pelo valor contratado, o que significa desperdício. Conforme texto extraído da resolução $n^{\circ} 456$, de 29 de Novembro de 2000, as definições para demanda contratada e demanda medida são:

Demanda contratada: demanda de potência ativa a ser obrigatoriamente e continuamente disponibilizada pela concessionária, no ponto de entrega, conforme valor e período de vigência fixados no contrato de fornecimento e que deverá ser integralmente paga, seja ou não utilizada durante o período de faturamento, expressa em quilowatts $(K W)$.

Demanda medida: maior demanda de potência ativa, verificada por medição integralizada no intervalo de 15(quinze) minutos durante o período de faturamento, expressa em quilowatts (KW) (ANEEL, 2000).

A contratação da demanda na indústria deve estar ligada diretamente à real necessidade para atender seu processo produtivo, buscando evitar ao máximo as oscilações pontuais de registros, uma vez que o pagamento da componente demanda na fatura mensal dar-se-á conforme o maior valor registrado.

Cabe então ao gestor de energia da fábrica fazer uma análise da curva de registro de demanda ao longo de um lote de produção e avaliar os valores de demanda medida, objetivando distribuir estas ocorrências ao longo do processo de produção, sempre que possível, tornando a curva de carga mais plana.

A utilização de controladores de demanda que registram e limitam os valores de demanda limitando o valor registrado ao valor estabelecido eliminando a ocorrência de ultrapassagens. Para isso é necessária uma análise identificando cargas prioritárias e não prioritárias no processo produtivo. Normalmente as cargas não prioritárias são os sistemas de refrigeração, compressores de ar 
comprimido, compressores de água gelada, entre outras. O controlador de demanda no momento de aumento da demanda do lado produtivo, desliga as cargas não prioritárias e permite religar no momento seguinte evitando a sobreposição das cargas ligadas concomitantemente, e garantindo que não haverá ultrapassagem da demanda em relação ao valor contratado.

A análise e a posterior instalação do controlador de demanda é uma ação que impacta diretamente na redução do patamar de contratação da demanda na indústria, proporcionando redução do valor total da fatura mensal.

Após identificado o valor ideal para a demanda a ser contratada, ou recontratada no caso de renovação contratual, necessária para atender o processo produtivo, é importante verificar o comportamento desta para poder readequar a contratação. Para tanto, a Resolução Aneel 456/2000 estabelece em seu Artigo 55:

Com o propósito de permitir o ajuste da demanda a ser contrata, a concessionária deverá oferecer ao consumidor o período de teste, com duração mínima de 3 (três) ciclos consecutivos e completos de faturamento, durante o qual será faturável a demanda medida, observados os respectivos segmentos horo-sazonais, quando for $o$ caso (ANEEL, 2000).

Cabe salientar que tal regulação se aplica quando da alteração da demanda a ser contratada e que por parte das distribuidoras há uma aceitação para o caso de aumento de carga ou nova instalação. Para redução de demanda deve ser considerado o prazo estabelecido na regulação, que exige 180 dias para comunicação:

Art. 23. O contrato de fornecimento, a ser celebrado com consumidor responsável por unidade consumidora do Grupo " $A$ ", deverá conter, além das cláusulas essenciais aos contratos administrativos, outras que digam respeito a: 
$\S 4^{\circ} \mathrm{A}$ concessionária deverá atender as solicitações de redução de demanda contratada não contempladas no art. 24, desde que efetuadas por escrito e com antecedência mínima de 180 (cento e oitenta) dias ${ }^{27}$.

Definida a demanda, cabe analisar os custos envolvidos em relação aos valores pagos pela demanda no horário de ponta e comparar com outras possibilidades que apresentem valores mais atrativos, pois a tarifa de demanda na ponta é bastante significativa na fatura mensal.

Exemplificando, o custo da energia para a unidade consumidora, como visto, é composto por duas parcelas. Uma correspondente à parcela da Potência (demanda) e a segunda parte, correspondente à energia (consumo registrado).

\section{$\boldsymbol{C}=\boldsymbol{a}$. Demanda $+\boldsymbol{b}$. Energia $[\mathrm{R} \$]$}

Onde: $\boldsymbol{a}$ = tarifa ou preço unitário do kW (demanda) [R \$/Kw]

Demanda $=$ Valor registrato ou contratado (o que for maior) $[\mathrm{kW}]$

$\boldsymbol{b}$ = tarifa ou preço unitário do kW.h (energia) [R $\$ / \mathrm{kWh}]$

Energia = Energia total consumida no período [kwh]

$\boldsymbol{C}=$ custo total da fatura (expurgado os encargos envolvidos). [R $\$]$

O fator de carga, esta definido pela fórmula:

$$
F_{c}=E_{t p} /\left(D_{m p} * T_{p e r}\right)
$$

\footnotetext{
${ }^{27}$ Art. 24. A concessionária deverá renegociar o contrato de fornecimento, a qualquer tempo, sempre que solicitado por consumidor que, ao implementar medidas de conservação, incremento à eficiência e ao uso racional da energia elétrica, comprováveis pela concessionária, resultem em redução da demanda de potência e/ou de consumo de energia elétrica ativa, desde que satisfeitos os compromissos relativos aos investimentos da concessionária, conforme previsto no $\S 1^{\circ}$ do art. 23.

Parágrafo único. O consumidor deverá submeter à concessionária as medidas de conservação a serem adotadas, com as devidas justificativas técnicas, etapas de implantação, resultados previstos, prazos, proposta para a revisão do contrato de fornecimento e acompanhamento pela concessionária, caso em que esta informará ao consumidor, no prazo de 45 (quarenta e cinco) dias, as condições para a revisão da demanda e/ou da energia elétrica ativa contratadas, conforme o caso.
} 
Onde: $\quad \mathbf{E}_{\mathrm{tp}}=$ Energia total consumida no período $[\mathrm{kWh}]$

$$
\begin{aligned}
& \mathbf{D}_{\mathrm{mp}}=\text { Maior demanda registrado } \mathrm{X} \text { faturado }[\mathrm{kW}] \\
& \mathbf{T}_{\text {per }}=\text { Período Total durante o mês }[\mathrm{hs}]
\end{aligned}
$$

Considerando um mês de 30 dias corridos, em que a leitura do medidor foi feita extamente às 00:00 hs do dia 01 e às 24 horas do dia 30, sem feriados, e quatro finas de semana, temos então: 22 dias úteis, que multiplicando por três horas do horário de ponta/dia, totalizará 66 horas de horário de ponta. Já para o horário fora de ponta temos 30 dias $\times 24$ horas $-(66$ horas ponta $)=654$ horas de operação no horário fora de ponta. Ou seja:

$$
\begin{aligned}
& \text { Na ponta: } \boldsymbol{D}_{\text {medp }}=\mathrm{E}_{\mathrm{p}} / \mathrm{T}_{\mathrm{p}} \\
& \text { Onde: } \quad \mathbf{E}_{\mathrm{p}}=\text { Energia total consumida no horário de ponta }[\mathrm{kWh}] \\
& \mathbf{T}_{\mathrm{p}}=\text { Período Total no mês na ponta [hs], para o mês de } 22 \\
& \text { dias úteis o valor é de } 66 \text { horas } \\
& \text { Fora de ponta: } \boldsymbol{D}_{\text {medp }}=\mathrm{E}_{\mathrm{fp}} / \mathrm{T}_{\mathrm{fp}} \\
& \text { Onde: } \quad \mathbf{E}_{\mathfrak{f p}}=\text { Energia total consumida no horário fora ponta }[\mathrm{kWh}] \\
& \mathbf{T}_{\mathrm{fp}}=\text { Período Total no mês fora ponta [hs], para o mês de } \\
& \text { 30, sendo } 22 \text { dias úteis o valor é de } 654 \text { horas }
\end{aligned}
$$

Isto posto, significa que o horário de ponta representa aproximadamente 10\% do total de horas produtivas no mês e o horário fora ponta representa os $90 \%$ restantes.

Entretanto, quando se avalia o valor pago em uma fatura de energia, pode-se notar que o valor total pago pela energia mais a demanda no horário de ponta equivale a aproximadamente $50 \%$ do valor total da fatura.

Em face ao citado, se paga um valor muito superior para produzir apenas 10\% do tempo total disponível no mês. As ações de redução de consumo no horário de ponta serão as que darão melhor resultado financeiro, além da analise referente a utilização da geração própria durante este período, por exemplo 
através de geradores de energia elétrica movidos a óleo diesel e/ou gás natural.

Cabe ainda uma análise através de simulação de gasto comparando as duas modalidades de contratação, THS verde ou THS azul. Esta simulação pode ser elaborada junto à concessionária. Quanto mais alto for o fator de carga no horário de ponta, para atender o processo produtivo, torna-se mais favorável a contratação na modalidade THS Azul, caso contrário, fator de carga baixo no horário de ponta, a modalidade THS Verde é a mais recomendada.

A Tabela 6.3 apresenta as diferentes tarifas na modalidade THS Azul e Verde.

Tabela 6.3 - Tarifas nas modalidades THS Azul e Verde - CPFL Paulista

\section{CPFL Paulista}

\section{Tarifa Azul}

\begin{tabular}{|c|c|c|c|c|c|c|c|c|}
\hline \multirow{2}{*}{ Sub Grupo } & \multicolumn{2}{|c|}{ Demanda } & \multicolumn{2}{|c|}{$\begin{array}{l}\text { Consumo Seco } \\
\text { (R\$/kWh) }\end{array}$} & \multicolumn{2}{|c|}{$\begin{array}{l}\text { Consumo Úmido } \\
\text { (R\$/kWh) }\end{array}$} & \multicolumn{2}{|c|}{$\begin{array}{l}\text { Ultrapassagem } \\
\text { (R\$/kWh) }\end{array}$} \\
\hline & Ponta & $\begin{array}{l}\text { Fora } \\
\text { Ponta }\end{array}$ & Ponta & Fora Ponta & Ponta & Fora Ponta & Ponta & Fora Ponta \\
\hline $\begin{array}{l}\text { A2 - Industrial e } \\
\text { Comercial }\end{array}$ & 16,15 & 2,11 & 0,31621 & 0,19424 & 0,28523 & 0,17628 & 48,45 & 6,33 \\
\hline A2 - Rural & 13,86 & 1,81 & 0,2714 & 0,16672 & 0,24482 & 0,1513 & 46,2 & 6,03 \\
\hline $\begin{array}{l}\text { A3 - Industrial e } \\
\text { Comercial }\end{array}$ & 22,48 & 4,21 & 0,31621 & 0,19424 & 0,28523 & 0,17628 & 67,44 & 12,63 \\
\hline A3 - Rural & 19,29 & 3,62 & 0,2714 & 0,16672 & 0,24318 & 0,1513 & 64,29 & 12,06 \\
\hline $\begin{array}{c}\text { A3a - Industrial e } \\
\text { Comercial }\end{array}$ & 22,59 & 5,14 & 0,31621 & 0,19424 & 0,28523 & 0,17628 & 67,77 & 15,42 \\
\hline $\begin{array}{l}\text { A4 - Industrial e } \\
\text { Comercial }\end{array}$ & 27,87 & 6,89 & 0,31621 & 0,19424 & 0,28523 & 0,17628 & 83,61 & 20,67 \\
\hline A4 - Rural & 23,92 & 5,91 & 0,2714 & 0,16672 & 0,24482 & 0,1513 & 79,74 & 19,71 \\
\hline
\end{tabular}

Tarifa Verde

\begin{tabular}{|c|c|c|c|c|c|c|}
\hline \multirow{2}{*}{ Sub Grupo } & \multirow{2}{*}{$\begin{array}{l}\text { Demanda } \\
\text { (R\$/kWh) }\end{array}$} & \multicolumn{2}{|c|}{$\begin{array}{l}\text { Consumo Seco } \\
\text { (R\$/kWh) }\end{array}$} & \multicolumn{2}{|c|}{$\begin{array}{l}\text { Consumo Úmido } \\
\text { (R\$/kWh) }\end{array}$} & \multirow{2}{*}{$\begin{array}{l}\text { Ultrapassagem } \\
\text { (R\$/kWh) }\end{array}$} \\
\hline & & Ponta & Fora Ponta & Ponta & Fora Ponta & \\
\hline $\begin{array}{c}\text { A3a - Industrial e } \\
\text { Comercial }\end{array}$ & 5,14 & 0,84072 & 0,19424 & 0,80974 & 0,17628 & 15,42 \\
\hline $\begin{array}{l}\text { A4 - Industrial e } \\
\text { Comercial }\end{array}$ & 6,89 & 0,96326 & 0,19424 & 0,93229 & 0,17628 & 20,67 \\
\hline A4 - Rural & 5,91 & 0,82677 & 0,16672 & 0,80018 & 0,1513 & 19,71 \\
\hline
\end{tabular}

Fonte: CPFL, 2009 ( tarifas publicadas do DOU de 08/04/2009) 
Para analisar o consumo de energia, os indicadores chaves são: (i) os valores consumidos mês a mês referenciados aos volumes de produção efetiva, (ii) 0 fator de carga nos horários de ponta e fora ponta e (iii) os custos envolvidos pagos por MWh.

Para o caso da empresa multifábricas, objeto de estudo, depois de finalizado os estudos e disseminado os critérios para a contratação de aos grupos responsáveis pelas unidades consumidoras, deu-se um novo passo que foi a análise da contratação de energia no mercado livre.

A análise comparativa das condições comerciais de contratação de energia elétrica na modalidade mercado livre, a partir do ano de 2004, motivou a opção por esta modalidade de contratação nas fábricas que atendiam às exigências mínimas, e apresentou importantes economias.

A modalidade cliente livre já difundida no Brasil nos seus submercados é a opção para o consumidor que quer negociar seus contratos, volumes e preços de energia que atenderá às suas necessidades por um período determinado.

Porém, o ambiente de contratação livre apresenta alguns riscos. Lemgruber (2001) apud Aguiar (2008) afirma que "o risco está presente em qualquer operação no mercado financeiro". Risco é um conceito multidimensional que cobre quatro grandes grupos: risco de mercado, risco operacional, risco de crédito e risco legal, todos inter-relacionados.

Aguiar (2008) citando Lima (2006) coloca que o risco de mercado de energia elétrica pode ser caracterizado como a combinação dos riscos de preços e de volumes, entendendo-se volume como a quantidade de energia elétrica utilizada pelos consumidores finais.

Acrescenta Aguiar (2008) que, como agente de mercado o consumidor livre está sujeito ao processo de liquidação na CCEE e desta forma há algumas variáveis a serem analisadas: (i) cobertura contratual para seu consumo no período de contabilização; (ii) se estará sujeito à diferença de preços entre submercados, e (iii) a que preço ocorreu a exposição. 
O Preço de Liquidação das Diferenças - PLD serve para a liquidação de toda a energia não contratada entre os agentes, e é determinado em base semanal para cada submercado. O PLD está atrelado ao Custo Marginal de Operação CMO e no longo prazo ao Custo Marginal da Expansão - CME, bem como pelo despacho de térmicas fora da ordem de mérito ${ }^{28}$. Aguiar (2008) citando Lima (2006) coloca que, na condição em que o CMO assume o mesmo valor do $\mathrm{CME}$, o custo de produzir uma unidade de energia elétrica com o parque gerador existente, é o mesmo que o custo de produzir uma unidade de energia elétrica com uma nova unidade geradora.

No caso de risco operacional no setor elétrico, Aguiar (2008) chama a atenção para a operacionalização dos contratos de energia, pois podem ocorrer erros tanto na determinação da sazonalidade, como no exercício de uma flexibilização contratual.

Quanto ao risco de crédito, este está atrelado ao processo de liquidação de curto prazo, havendo um equilíbrio de contas, ou seja, o somatório de todos os montantes credores coincide com os montantes devedores, havendo neste caso um agente perdedor e outro ganhador. Os aportes de garantias financeiras deverão ser suficientes para cobrir o montante devedor (AGUIAR, 2008).

Aguiar (2008) associa o risco legal à celebração de contratos no mercado livre, devendo o contratante, estar atento aos aspectos como (i) o exercício da flexibilidade, (ii) as multas por descumprimento das obrigações, (iii) as garantias financeiras e (iv) termos para a rescisão contratual, evitando prejuízos futuros.

As regras de comercialização de energia sofrem alterações, como as ocorridas em 2009. Deve-se estar atento às mudanças.

\footnotetext{
28 Ao longo de 2008 o governo determinou que as usinas térmicas entrassem em funcionamento a qualquer custo para poupar água dos reservatórios. A medida contrariou os critérios historicamente utilizados que prevêem a operação das usinas mais baratas antes das mais caras, para benefício do consumidor.
} 
Os riscos foram avaliados na indústria estudada pela equipe de compra de energia nas unidades que atendiam aos critérios para ingresso no mercado livre.

A grande diferença entre o cliente livre e o regulado é que o primeiro tem a possibilidade de negociar previamente os valores que irá pagar pela energia, entretanto tem que definir antecipadamente o montante de energia de que irá precisar durante a vigência do contrato. Já na situação regulado terá que submeter-se às tarifas definidas pela Aneel, porém sem o compromisso de pagar pela energia não utilizada, caso o seu negócio passe por uma dificuldade.

Também existem riscos no ambiente de contratação regulada. Para Kelman (2006) a percepção de risco é fortemente influenciada por três temores: (i) Legislativo, pelo fato de alguma turbulência política mudar precipitadamente o atual marco regulatório, que oferece um bom conjunto de regras para o setor, sem dar tempo para se acumular experiência; (ii) Judiciário, caso alguns tribunais de primeira instância, e os chamados tribunais de pequenas causas, ignorem a existência de uma agência reguladora e a substituam na tomada de decisões de alta complexidade técnica; (iii) a falta de autonomia administrativa da Aneel, tanto no que diz respeito à política de pessoal quanto à execução orçamentária, comprometa a independência decisória da diretoria colegiada e a capacitação técnica dos servidores.

O livre acesso ao sistema de distribuição, independentemente de suas localizações no sistema interligado, possibilita a comercialização direta entre produtores e consumidores. Os encargos do uso do sistema de distribuição devem ser suficientes para a prestação destes serviços e são devidos aos concessionários distribuidores. Importante ressaltar que as tarifas de uso do sistema são reguladas, não fazendo parte da negociação para a migração ao ambiente de contratação livre.

As Figuras 6.6 a 6.10 apresentam os resultados obtidos quando da migração para o mercado livre de algumas unidades da indústria estudada, com comentários gerais do gestor de energia. 
O Valor Presente Líquido - VPL, para cada caso, foi calculado considerando-se a diferença entre, o valor que seria pago como consumidor regulado, considerando um reajuste anual futuro de variação do IGPM e somando-se $2 \%$ a.a,, como fator de segurança, o montante que seria pago pelo contrato firmado como consumidor no mercado livre, trazido a valor presente a uma taxa de $12 \%$ a.a.

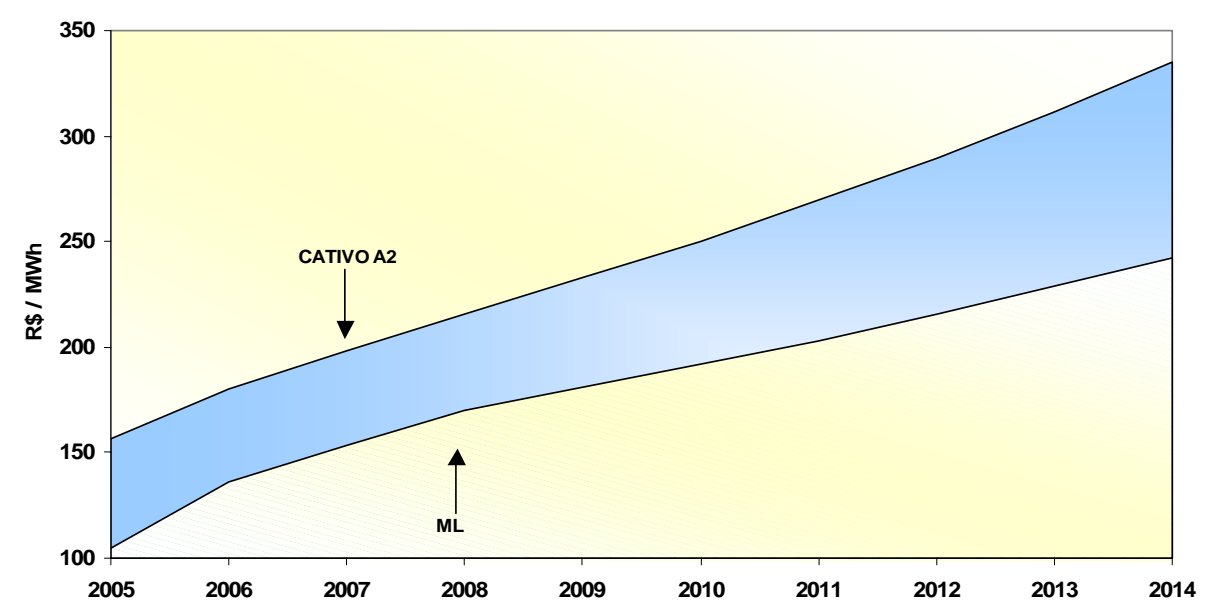

Figura 6.6 - Comparativo Unidade $A=>M L X$ Cativo (IGPM + 2\%)

Valor Presente Líquido - VPL = R\$16,1 milhões de economia gerada esperada

Comentários: Contrato vigente de janeiro de 2005 a Dezembro de 2014

- necessidade da gestão mensal entre a energia comprada e a consumida

- aumentam os procedimentos administrativos (3 faturas por mês)

- a energia registrada tem ficado dentro do previsto

- maior organização para os trâmites financeiros

- economia efetiva no primeiro ano (2005) $=\mathrm{R} \$ 2,0 \mathrm{Mi}$

- previsão de economia para todo o contrato $=\mathrm{R} \$ 16,1 \mathrm{Mi}$

A linha inferior do gráfico acima e dos demais quatro casos que seguem, mostra o preço da energia elétrica que seria paga ao longo do contrato que se iniciou em 2005 e terminará em 2014.

A linha diagonal superior mostra o preço que seria pago pela mesma energia, caso o contrato foi assinado dentro do ambiente regulado. 
A área central destacada em azul apresenta o montante economizado projetado ao longo do tempo.

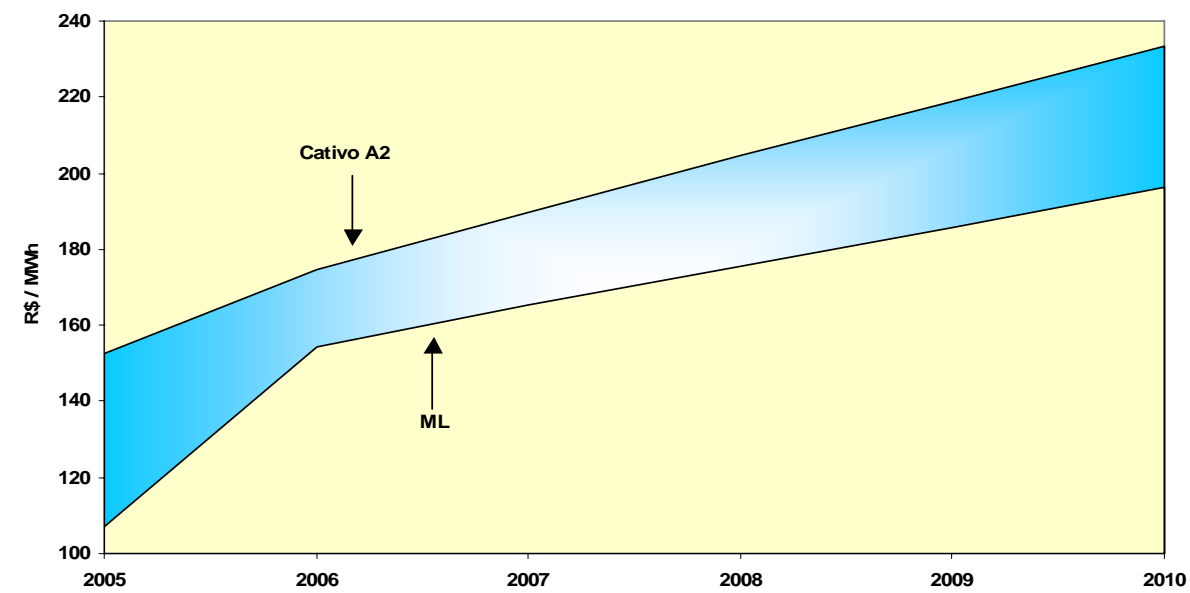

Figura 6.7 - Comparativo Unidade B => ML X Cativo (IGPM + 2\%) $\mathrm{VPL}=\mathrm{R} \$ 8,8$ milhões de economia gerada

Comentários: Contrato de Junho de 2005 a Dezembro de 2010

- necessário um controle mensal (contabilização)

- maior organização para os trâmites financeiros

- economia efetiva no primeiro ano (2005) = R\$ 1,6 Mi.

- economia prevista no contrato $=\mathrm{R} \$ 8,8 \mathrm{Mi}$.

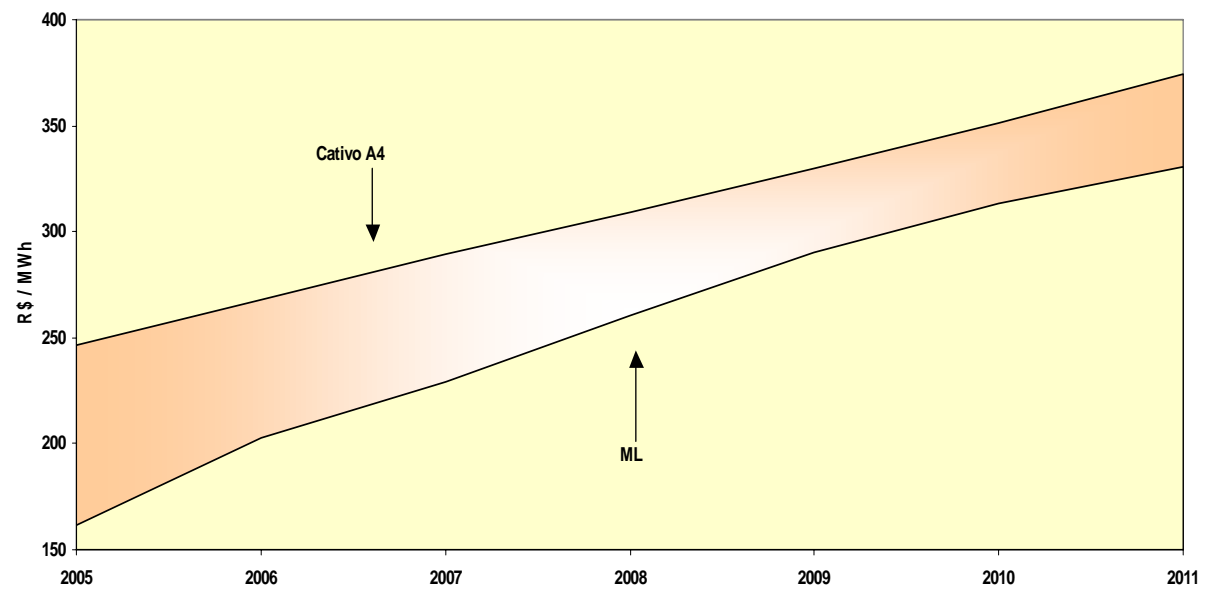

Figura 6.8 - Comparativo Unidade C => ML X Cativo (IGPM + 2\%)

$\mathrm{VPL}=\mathrm{R} \$ 4,2$ Milhões de economia gerada 
Comentários: contrato de junho de 2005 a maio de 2011

- Migração para o Mercado Livre foi acordada com a CEMIG

- Facilidade do cadastramento na CCEE

- Maior organização para os trâmites financeiros

- Economia efetiva no primeiro ano (2005) $=\mathrm{R} \$ 600 \mathrm{mil}$

- Economia prevista no contrato $=\mathrm{R} \$ 4,2 \mathrm{Mi}$

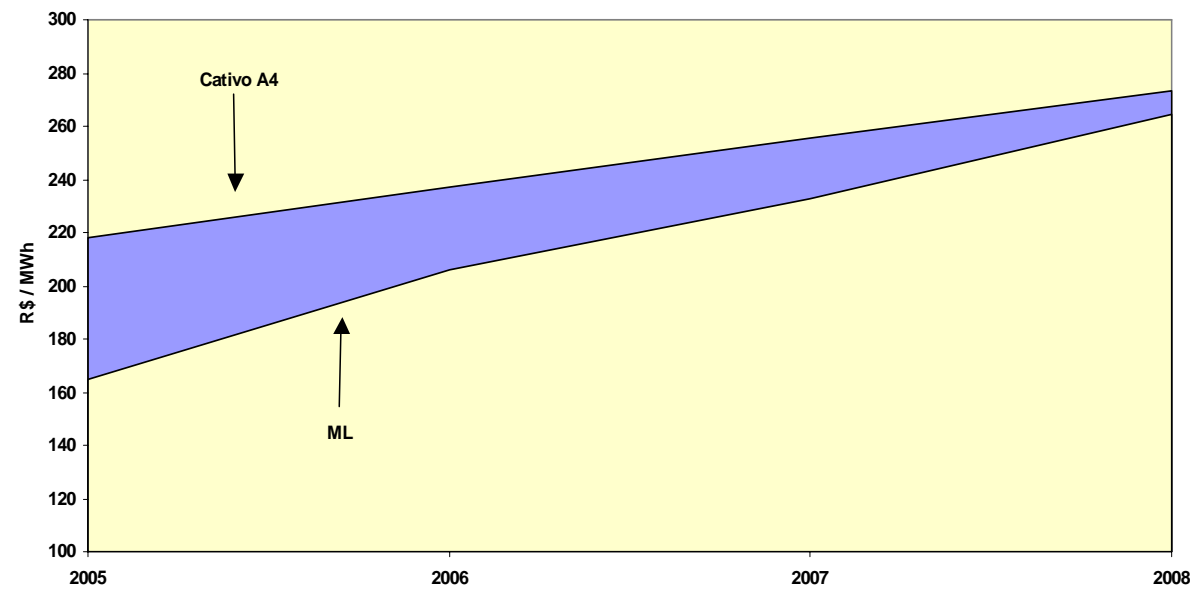

Figura 6.9 - Comparativo Unidade D => ML X Cativo (IGPM + 2\%)

$\mathrm{VLP}=\mathrm{R} \$ 680$ mil de economia gerada

Comentários: Contrato de julho de 2005 a junho de 2008

- Migração para o Mercado Livre foi acordada com a Cemig

- Os preços a partir de 2008 não foram atrativos

- Economia efetiva no primeiro ano (2005) = R $\$ 200$ mil

- Economia prevista no contrato $=\mathrm{R} \$ 680 \mathrm{mil}$

Neste caso em específico, em função da forma de reajuste do valor da energia elétrica apresentado em contrato, foi identificado que a partir de 2008 o valor da energia elétrica projetado poderia ser maior que a energia no mercado regulado.

Optou-se por assinar o contrato apenas até 2008 e apartir de então retornar ao mercado regulado. 


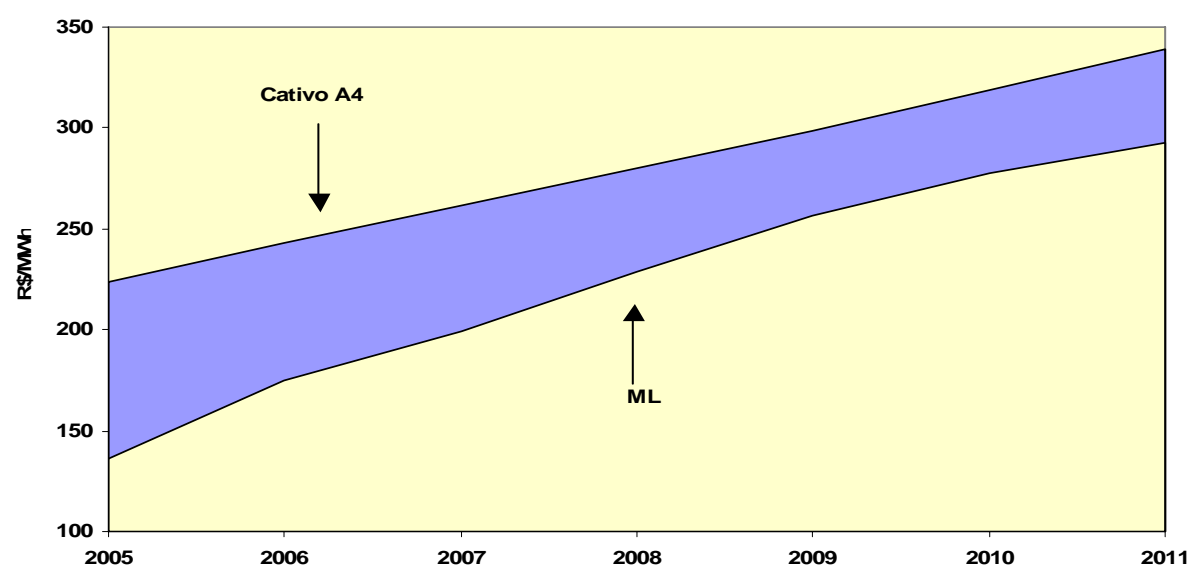

Figura 6.10 - Comparativo Unidade E => ML X Cativo (IGPM + 2\%)

$\mathrm{VLP}=\mathrm{R} \$ 6.6$ Milhões de economia gerada

Comentários - Contrato de julho de 2005 a junho de 2008

- Migração para o Mercado Livre acordada com a CEMIG

- Maior organização dos trâmites financeiros

- Economia efetiva no primeiro ano (2005) $=\mathrm{R} \$ 800$ mil

- Economia prevista no contrato $=\mathrm{R} \$ 6.6 \mathrm{Mi}$.

Para a definição da quantidade de energia que fora contratada, observou-se a sazonalidade do processo produtivo, a flexibilização que atenderia a necessidade ao longo dos anos sub-sequentes e a modulação da carga no longo do primeiro ano de contrato. A figura 6.11 ilustra o que representa cada um destes termos. 


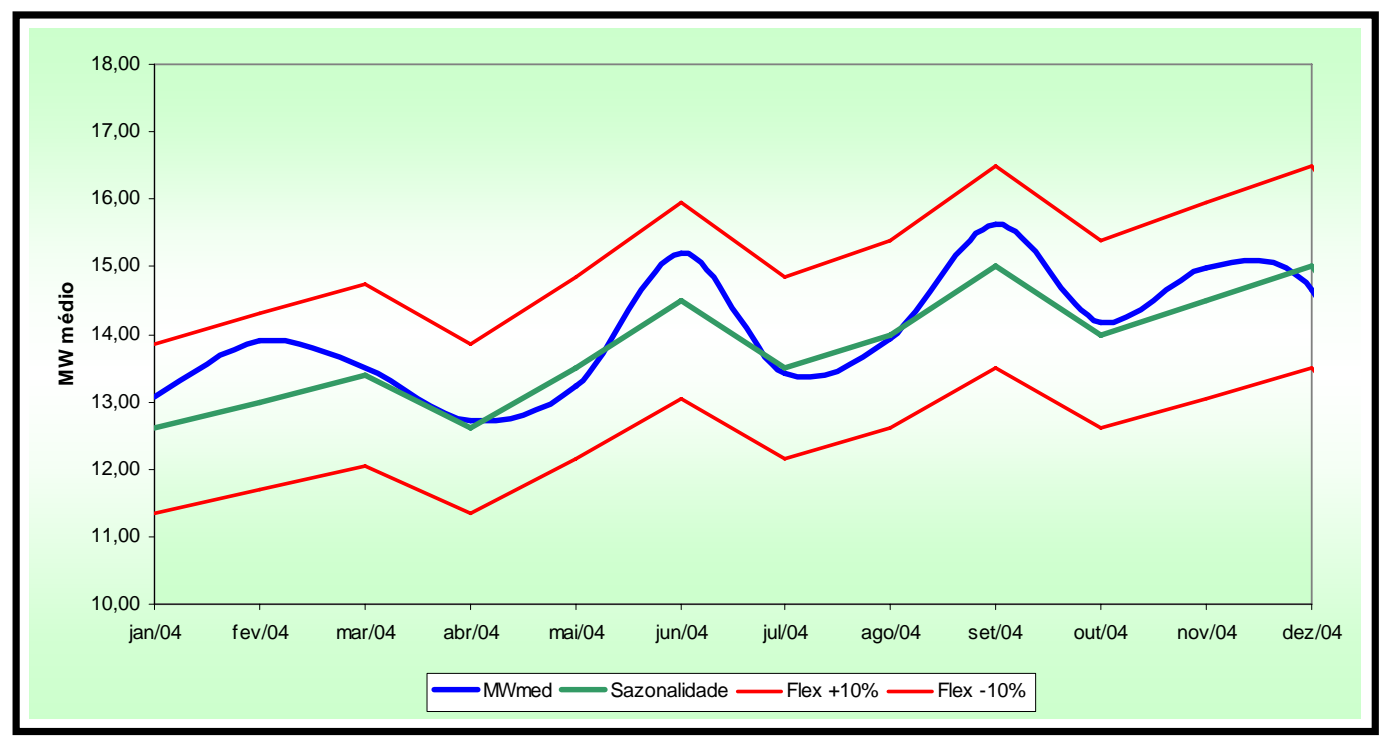

Figura 6.11 - Sazonalidade, flexibilização e modulação de carga.

Sazonalidade $=$ Representada em verde no gráfico mostra a quantidade de energia em MWmédio, necessária mensalmente ao longo de um ano para atender o processo produtivo, Neste exemplo não se configura uma sazonalidade, apenas um aumento de consumo ao longo do ano.

Flexibilidade $=$ Representada em vermelho mostra a variação aceitável mensal de consumo de energia, frente ao contrato de fornecimento, sem que o consumidor tenha que pagar a mais do que o combinado.

Modulação = Representada em verde apresenta a divisão em doze meses do montante de energia comprado contratado para aquele ano. Esta dividida em três patamares de carga: Leve, Média e Pesada, objetivando uma diferenciação de preço para a energia conforme o horário de uso e com preços diferenciados.

MWmédio = Representado em azul o consumo registrado ao longo do ano, sem que em nenhum momento houvesse ultrapassagem ou não utilização do volume de energia contratado.

Na Figura 6.11, esta exemplificado, uma contratação que atendeu durante aquele ano, a necessidade produtiva sem ultrapassagens de registro de consumo acima, bem como sobra de energia abaixo da flexibilidade 
estabelecida em contrato. A linha verde mostra o consumo projetado para doze meses, o azul o efetivo registrado. Neste caso a contratação atendeu a necessidade da unidade consumidora sem expô-la as penalidades aplicadas pela CCEE, quanto a estar descoberto no montante de energia contratada a cada mês, bem como a exposição ao custo spot não planejado.

Ainda quanto às oportunidades de redução de gastos com a fatura de energia elétrica, a geração própria deve ser considerada avaliando-se a alternativa frente a migração para o mercado livre.

Quando se compara os custos de energia no mercado regulado frente ao mercado livre, não se pode esquecer que existe ainda a possibilidade de manter-se contratado no ambiente regulado, porém utilizando a geração própria na ponta, há casos que esta ação é mais vantajosa avaliando do lado custo total da energia.

A geração própria ocorre quando da utilização de grupos geradores, com motores à combustão, ou mesmo através da utilização do vapor produzido na caldeira da planta passando por uma turbina geradora.

No projeto de geração através de motores à combustão deve-se avaliar ainda a disponibilidade e o custo do combustível a ser utilizado, neste caso o gás natural ou GLP, ou o óleo combustível, normalmente óleo diesel.

Esta opção de projeto tem por característica a rápida instalação, com investimento baixo, porém o custo de operação $(R \$ / k W h)$ será alto em relação ao custo praticado pela concessionária.

Este tipo de projeto é recomendado em regiões onde a infra-estrutura existente não atende a necessidade, ou mesmo em regiões onde existe um crescimento rápido e não planejado, como o exemplo citado da planta no Rio Grande do Sul.

A maioria das usinas de álcool, que trabalham todo o período produtivo a plena carga e necessitam do vapor como parte de seu processo, passaram a utilizar a geração própria e a venda do excedente de energia gerado, sendo que tal receita passou a incorporar a lista de dividendos obtidos com a utilização da cana. 
Neste caso o combustível queimado na caldeira é o próprio bagaço de cana que garante um custo baixo na produção de vapor e de energia elétrica, possibilitando à usina comercializar os seus excedentes de energia elétrica diretamente com a concessionária ou consumidores livres.

Em contra partida, o inconveniente da geração de energia através de caldeira de vapor, é que a energia somente está disponível quando está em funcionamento. O processo deveria ser constante e contínuo para se poder atender o consumidor livre diretamente. Uma forma de eliminar esta falta de fornecimento durante a entressafra, a mesma energia poderia ser obtida através da queima de um outro tipo de biomassa ou mesmo de um combustível fóssil.

Na geração através de geradores movidos á gás ou mesmo óleo combustível, pode ser regulada conforme a real necessidade, a cada momento do dia ou da semana.

Um projeto de autoprodução de energia pode contemplar a comercialização dos excedentes gerados, o que requer a conexão com rede da concessionária, bem como um possível contrato adicional de energia, para garantir a disponibilidade, mesmo no momento de falha do sistema de geração própria.

\subsection{A Eficiência Energética na Indústria de Alta e Média Tensão}

A indústria vem buscando oportunidades de investimentos em projetos de eficiência energética, ano a ano, seja com recursos próprios, através da Lei ${ }^{29}$ 9.991 de 2000, ou mesmo através das ESCO (Energy Saving Company), empresas que investem recursos próprios em projetos de redução de consumo de energia na indústria e compartilham do lucro obtido com a redução verificada nas faturas de energia.

\footnotetext{
${ }^{29}$ Dispõe sobre realização de investimentos em pesquisa e desenvolvimento e em eficiência energética por parte das empresas concessionárias, permissionárias e autorizadas do setor de energia elétrica.
} 
A primeira iniciativa governamental, estruturada, voltada para a eficiência energética data de 1985 quando foi instituído o Procel - Programa Nacional de Conservação de Energia Elétrica, criado pelos Ministérios de Minas e Energia e da Indústria e Comércio, sendo transformado em 1991 em Programa de Governo. Neste ano foi instituído por Decreto Federal o Conpet - Programa Nacional de Racionalização do Uso de Derivados do Petróleo e do Gás Natural, tendo como principal objetivo o uso eficiente destas fontes de energia não renováveis no transporte, nas residências, no comércio, na indústria e na agropecuária.

Em 26/10/1990, através do Decreto 99.656, tornou-se obrigatória a existência da Comissão Interna de Conservação de Energia - CICE, em cada estabelecimento pertencente a órgão ou entidade da Administração Federal direta e indireta, fundações, empresas públicas e sociedades de economia mista controladas direta ou indiretamente pela União. O limite dessa obrigatoriedade era ditado pelo consumo anual de energia elétrica superior a $600.000 \mathrm{kWh}$, ou consumo anual de combustível superior a 15 TEPs.

Porém, somente em 2000 foi definida, por meio da Lei 9.991, a obrigatoriedade de aplicação de recursos, pelas concessionárias e permissionárias de energia elétrica, em pesquisa, desenvolvimento e em projetos de eficiência energética, desenvolvendo medidas que promovessem o combate ao desperdício de energia.

A necessidade de maior eficiência no uso da energia foi reforçada através da Lei $n^{\circ} 10.295$, de 17 de outubro de 2001, que dispõe sobre a Política Nacional de Conservação e Uso racional de Energia, visando a alocação eficiente de recursos energéticos e a preservação do meio ambiente, incumbindo ao poder executivo o estabelecimento de níveis máximos de consumo específico de energia, ou mínimo de eficiência energética de máquinas e aparelhos consumidores de energia fabricados ou comercializados no País.

Entre as diversas categorias de consumidores determinadas pela Lei 9.991, que devem ser contempladas pelas concessionárias e permissionárias em projetos de eficiência energética, destacam-se a industrial e a de grandes consumidores, com inúmeras possibilidades de elaboração de projetos que 
possam reduzir significativamente os níveis de consumo de energia, em relação ao consumo verificado antes da execução do projeto.

O maior interesse em intensificar ações de eficiência energética na indústria decorre da forte presença desse setor no consumo final de energia. A estrutura do consumo de energia elétrica entre os segmentos de consumidores mostra uma forte concentração do seu uso na indústria, com $46,7 \%$ do consumo total, seguido do uso residencial, com 22,1\%, como demonstrado na Figura 6.12 (BEN, 2008)

Poucas variações ocorreram no período de 1970 a 2005, tendo o setor industrial iniciado processo de ligeira queda de participação a partir da segunda metade da década de 80 , mas mostrando recuperação nos últimos anos. A queda verificada nos anos de 2001 e 2002 é decorrente das restrições impostas pelo racionamento de energia elétrica, que atingiu todas as classes de consumidores (BEN, 2008)

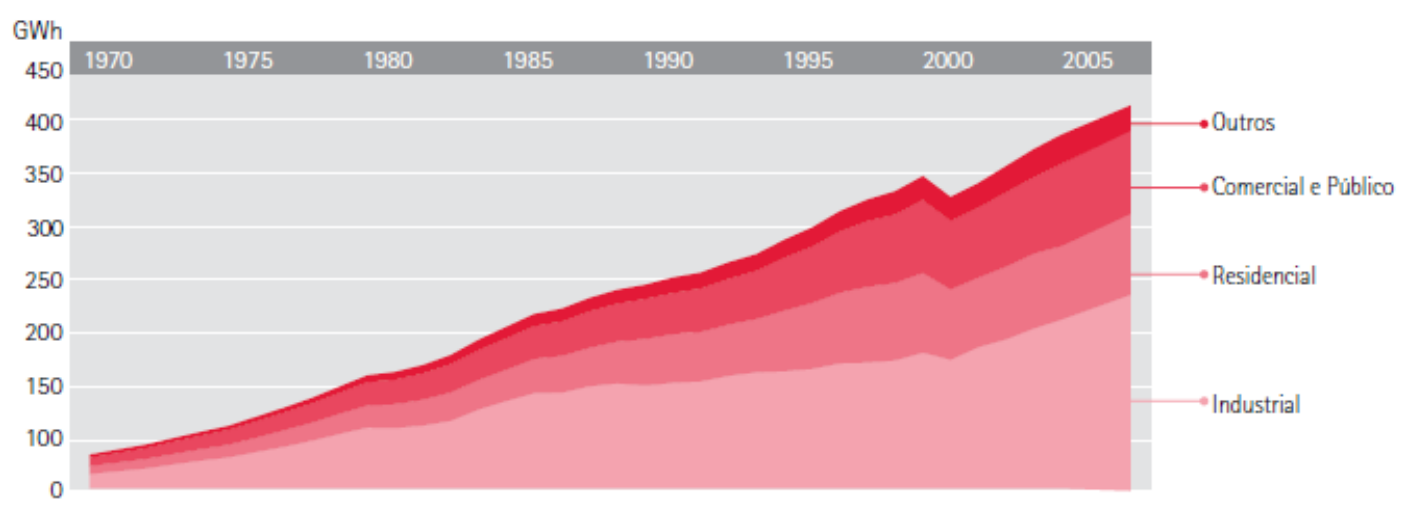

Figura 6.12 - Evolução dos Consumos Setoriais de Energia Elétrica Fonte: BEN, 2008

Várias ações voltadas para a eficiência energética podem ser implementadas pela indústria, dentre estas:

- Substituição de lâmpadas e instalação de sensores de presença: a substituição de lâmpadas incandescentes por fluorescentes, aliada a readequação do sistema de iluminação e o acionamento de iluminação 
em cada tempo nos diversos ambientes, pode trazer uma significativa redução de custos à indústria;

- Instrumentação e Controle (Medição e Verificação): processos de monitoração que constituem uma forma de controle de informações dos processos de produção e podem apontar soluções e melhorias ao processo industrial;

- Substituição do Sistema de Climatização e Refrigeração: a substituição do sistema de climatização de ambientes e de refrigeração industrial e comercial, por equipamentos eficientes e de menor consumo podem, gerar uma economia com os gastos em energia elétrica;

- Substituição de Motores e sua respectiva carga: a força maior da indústria e também os responsáveis pelo maior consumo de energia, os motores com suas respectivas cargas, por ex. bombas, compressores, etc..., podem ser substituídos por modelos mais eficientes, com um menor consumo;

- Acionamento Eletrônico de Equipamentos: acionamentos eletrônicos para o controle e vazão em processos de bombeamento, em substituição aos controles tradicionais, apresentam um potencial de até $30 \%$ em economia de energia.

$\mathrm{Na}$ seqüência apresenta-se uma das ações voltadas para a eficiência energética na indústria, desenvolvida na indústria estudada por este autor, apresentando a metodologia e os resultados obtidos com a eficientização energética realizada em seu parque de ar comprimido.

Este projeto concorreu e foi o segundo colocado no prêmio FIESP de conservação de Energia Elétrica no ano de 2004.

A situação encontrada na indústria no sistema de geração de ar comprimido está esquematizada na Figura 6.13. 


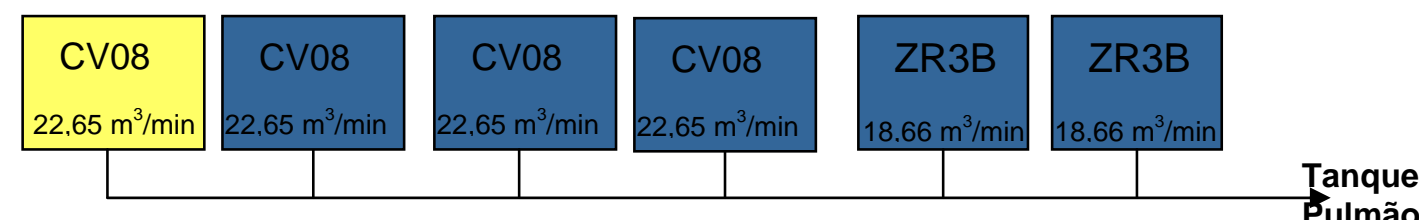

Pulmão

DEMANDA LOCAL REGISTRADA: $719 \mathrm{KW} \quad$ Vazão consumida - 105,27 $\mathrm{m}^{3} / \mathrm{min}$

Vazão max. $\quad-127,92 \mathrm{~m}^{3} / \mathrm{min}$

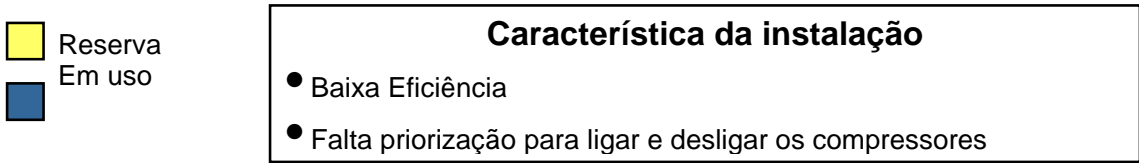

\section{Figura 6.13 - Situação encontrada na planta de ar comprimido}

Fonte: Elaboração própria utilizando os dados do sistema de ar comprimido da indústria estudada

Conforme exemplificado, o sistema de geração de ar comprimido era composto por cinco compressores em serviço e um de reserva, trabalhando em paralelo com controles independentes, sendo que a capacidade total da planta era de $127,92 \mathrm{m3} / \mathrm{mim}$ e a demanda registrada no local era de $719 \mathrm{~kW}$.

A capacidade individual de cada compressor era de 22,65 m3/min com motores de 250 CV para os modelos CV08, e de 18,66 m3/mim com motores de $175 \mathrm{CV}$ para os modelos ZR.

O projeto foi proposto pela concessionária Elektro, baseado em um projeto similar já executado. A concessionária coordenou e implantou o projeto, visto que, ela assumiu o investimento total usando recursos da lei 9991.

Parte do investimento total para a realização do projeto foi considerado como fundo perdido (sem retorno financeiro do capital ao investidor), e o restante do investimento foi pago pela empresa estudo de caso, em parcelas mensais com valores nunca maiores do que a economia verificada em $\mathrm{R} \$$, ou seja o fluxo de caixa durante a amortização do projeto foi sempre positivo.

A empresa fabricante dos novos compressores, junto com a concessionária elaboram e instalaram dois novos compressores conforme figura 6.14 . 


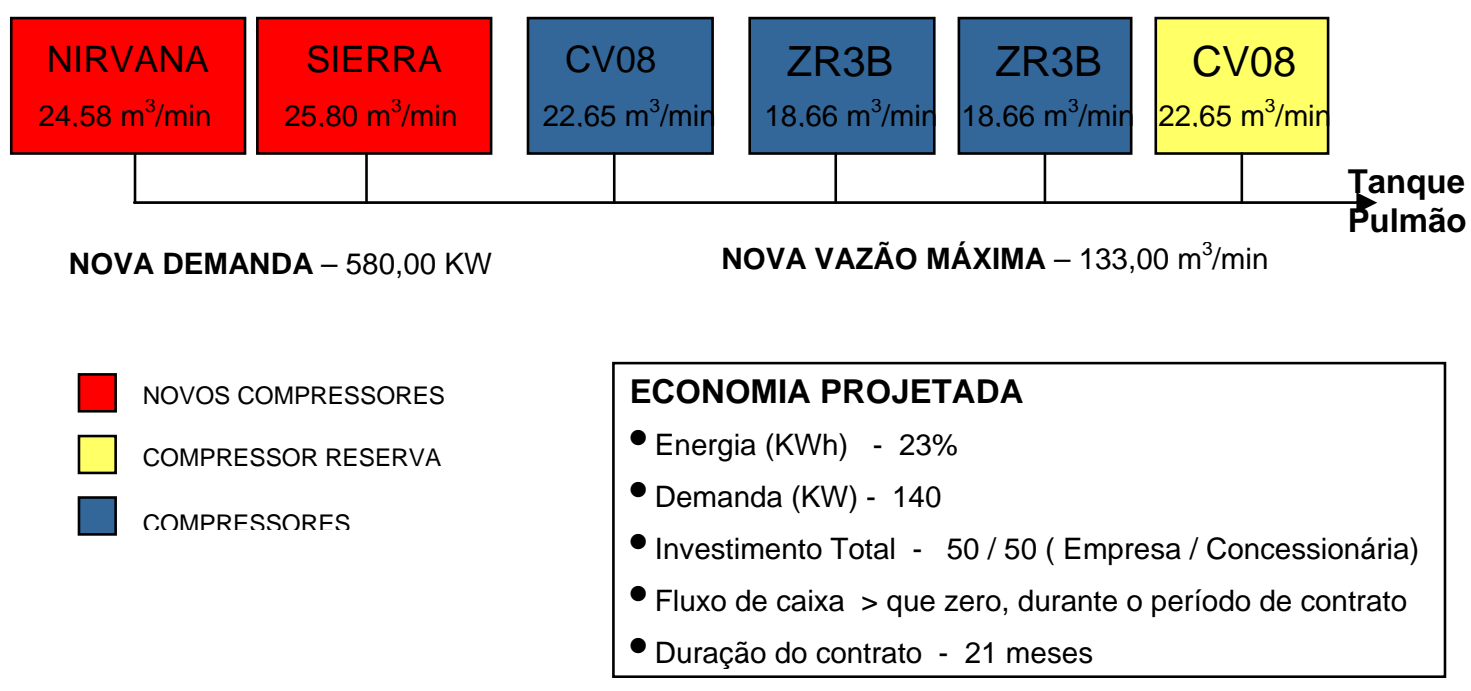

\section{Figura 6.14 - Instalação do Sistema Ideal de Ar Comprimido}

Fonte: Elaboração própria utilizando os dados do sistema de ar comprimido da indústria

Para controle de todos os Compressores na nova proposta, foi instalado um Sistema para Gerenciamento (IEO - Intellisys Energy Optimizer), de modo a manter os compressores antigos além do novo (SIERRA), trabalhando com velocidade de trabalho fixa de $100 \%$ durante o tempo que estivesse ligado.

O novo compressor Nirvana, que possui um sistema de vazão controlada através da utilização de inversor de freqüência, trabalharia no ajuste fino gerando apenas o necessário para suprir a demanda total da fábrica.

No sistema anterior a falta do controlador de gerenciamento e do compressor com inversor de freqüência não permitia tal controle e isto significava que não havia prioridade para ligar ou desligar o conjunto de compressor e a cada variação de necessidade de consumo, significava partir e/ou parar um motor de 175, ou de $250 \mathrm{CV}$, gerando picos de partida de motores que impactavem na demanda e no consumo de energia.

Com o novo sistema de controle, a pressão de fornecimento de ar é mantida praticamente constante, eliminando as flutuações de pressão, através do compressor com vazão variável, que garante os demais compressores sempre ligados em carga máxima, que o ponto mais eficiente da curva de trabalho deste tipo de compressor. 
Para medição do rendimento do sistema de geração de ar comprimido, foram registradas as variáveis potência efetiva dos compressores e vazão de ar produzido em cada compressor nas condições normais de operação.

As medições das principais grandezas envolvidas estão descritas a seguir:

- Levantamento da Vazão produzida

A vazão produzida pelos compressores foi levantada por um medidor de vazão tipo turbina de inserção, instalado na saída do Tanque Pulmão.

- Levantamento da Potência Efetiva dos Compressores

Para o levantamento do perfil das potências consumidas foram realizadas as medições das potências ativas, efetivamente consumida em cada compressor, através de analisadores de rede, simultaneamente à medição de corrente de uma fase de cada equipamento. Deste modo foi possível o levantamento do perfil de Potência em função do levantamento dos perfis de corrente dos compressores.

- Período de Levantamento do Perfil de Consumo e Produção de Ar

Para o levantamento do Rendimento do Sistema de Geração de Ar Comprimido, foi considerado o levantamento das correntes e vazões dos Compressores pelo período de sete dias.

Estes levantamentos apresentaram os seguintes resultados:

- Aferição Corrente X Potência Efetiva - as figuras 6.15, 6.16 e 6.17 apresentam os registros de Corrente e Potência levantados no período de aferição, possibilitando o relacionamento das Potências dos Compressores com as correntes registradas. Para cada Compressor foi encontrado um Fator de Relação (R) possibilitando a definição da Potência Efetiva em kW a partir da corrente de uma fase em Ampere (A). 


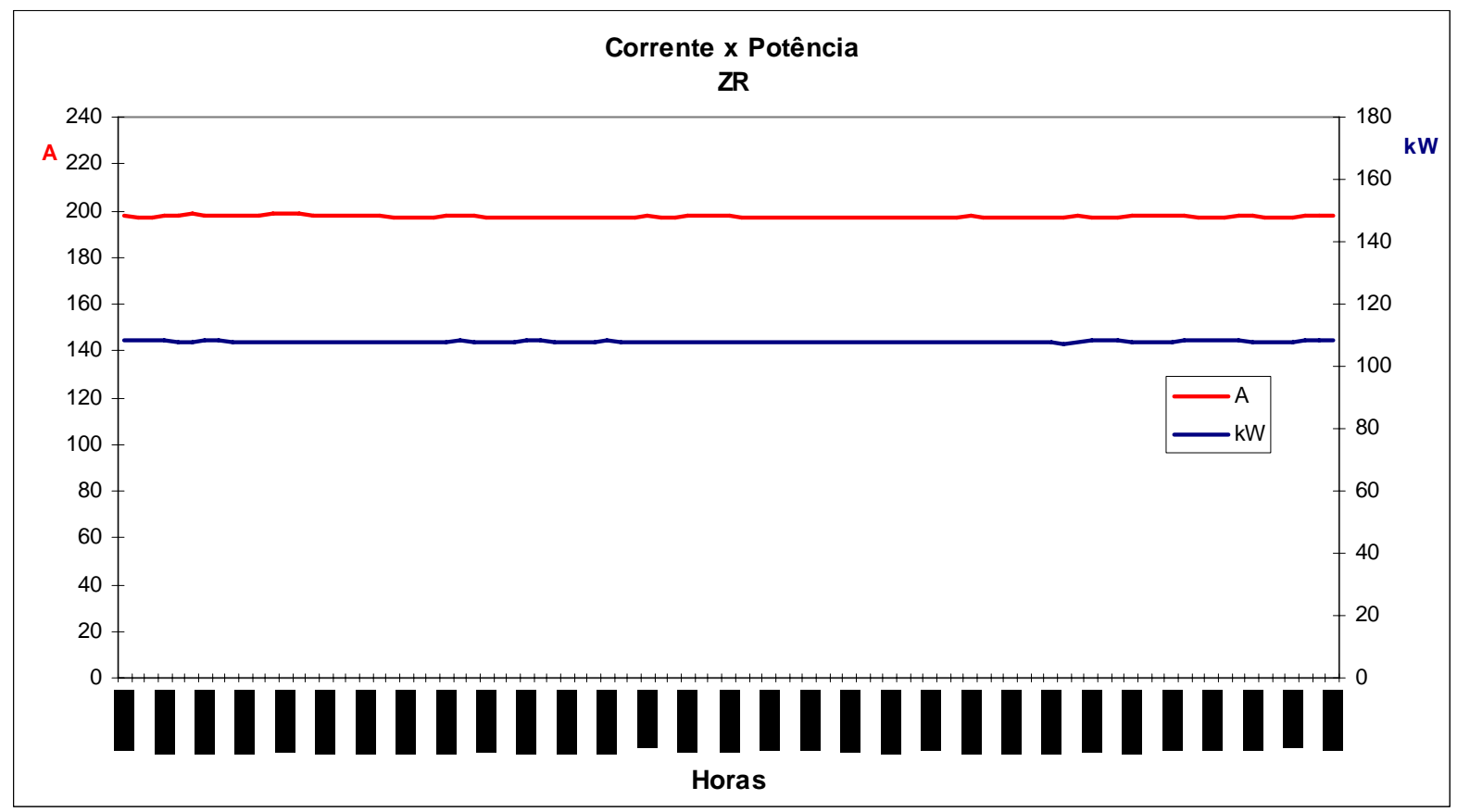

Figura 6.15 - Registros de Corrente e Potência - Compressores ZR

Fonte: Dados registrados a partir de medição e registro do medidor da indústria

Fator de Relação $(R)$ entre a corrente medida e a Potência Efetiva:

$R=i(A) / P(k W) R=197 A / 108 k W \quad R=\mathbf{1 , 8 3}$

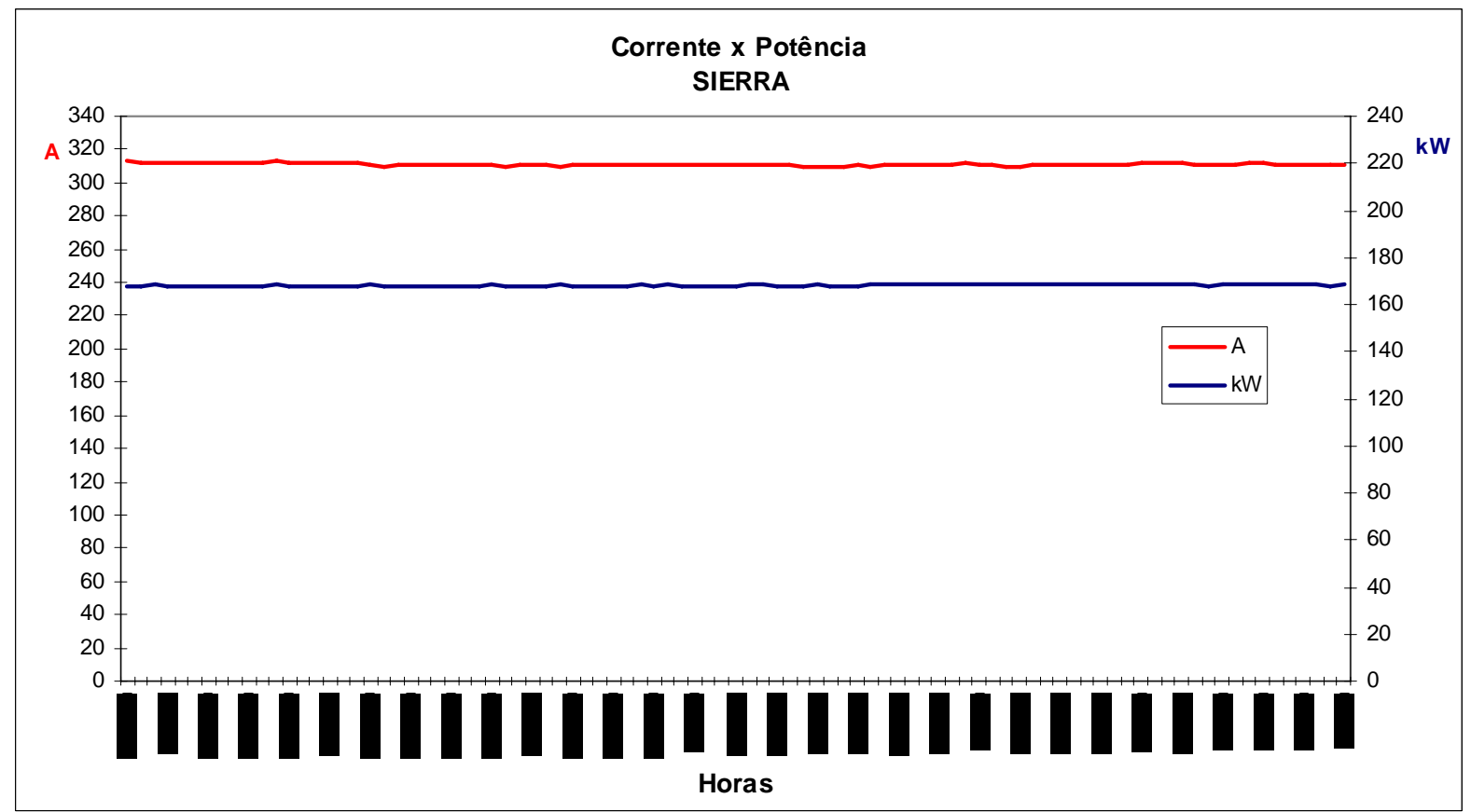

Figura 6.16 - Registros de Corrente e Potência - Compressor SIERRA

Fonte: Dados registrados a partir de medição e registro do medidor da indústria 
Fator de Relação (R) entre a corrente medida e a Potência Efetiva:

$R=i(A) / P(k W) \quad R=311 A / 168 k W \quad R=1,85$

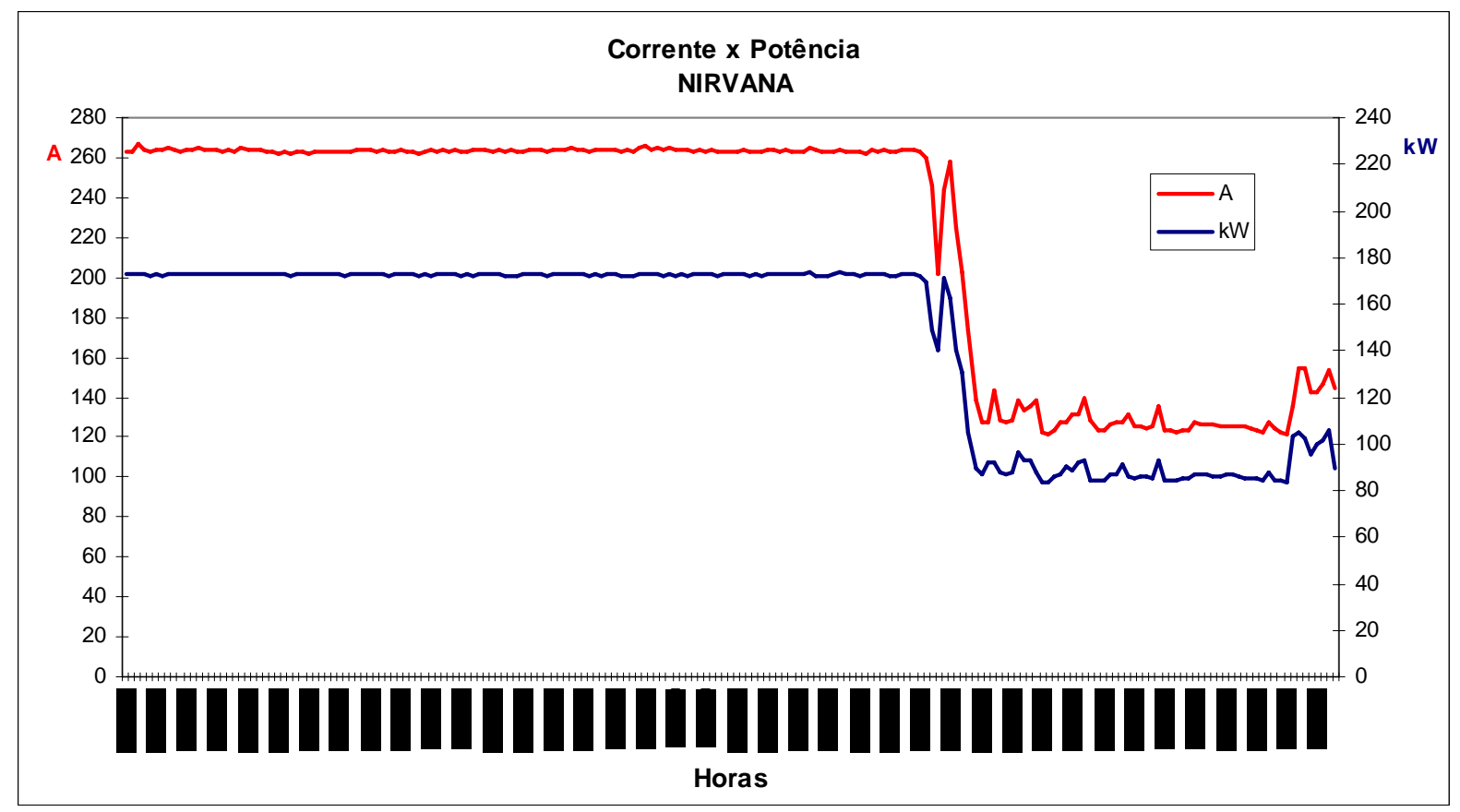

Figura 6.17 - Registros de Corrente e Potência - Compressor NIRVANA

Fonte: Dados registrados a partir de medição e registro do medidor da indústria

Fator de Relação $(R)$ entre a corrente medida e a Potência Efetiva:

$R=i(A) / P(k W) R=222 A / 146 k W \quad R=1,52$

Nota-se a redução de consumo de energia elétrica no compressor NIRVANA em relação aos compressores de velocidade fixa, isto porque, o consumo de energia elétrica é proporcional a geração de ar comprimido.

Antes da implantação deste projeto a cada momento em que havia a redução de consumo de ar comprimido no processo produtivo, havia um desligamento de um dos compressores, sem nenhuma priorização, no momento seguinte 0 mesmo compressor voltava a ligar para voltar a suprir o processo produtivo. Com a instalação do o Compressor Nirvana, ou outro com a mesma característica de variação de vazão de ar através de inversor de frequência, mais o controlador que gerencia a entrada e saída dos demais compressores, pode-se evitar que uma planta de ar comprimido fique a todo momento ligando 
e desligando um motor de grande porte para poder atender a necessidade da produção.

A partir dos levantamentos dos perfis de vazão e potência do sistema de geração de ar comprimido, e dos valores mádios destas grandezas, foi calculado a economia efetiva:

- Potência média registrada $=461$ kW

- Vazão média registrada $=\mathbf{3 . 6 9 2} \mathrm{m}^{3} / \mathrm{h}$

- Demanda máxima do Sistema de Compressores = 563 kW

Para o cálculo do consumo foi considerada a Potência Média:

Consumo médio $=(461 \mathrm{~kW} \times 730 \mathrm{~h} / \mathrm{mês}) / 1.000$ kW/MW $=336$ MWh/mês

Consumo médio = $336 \mathrm{MWh} / \mathrm{mês} \times 12$ meses/ano = $4.038 \mathrm{MWh} / \mathrm{ano}$

O cálculo do rendimento atual do período considerou:

Consumo específico = Potência Média $/$ Vazão Média

Consumo específico $=461 \mathrm{~kW} / 3.692 \mathrm{~m}^{3} / \mathrm{h}=0,1249 \mathrm{~kW} / \mathrm{m}^{3} / \mathrm{h}$

$0,1249 \mathrm{~kW} / \mathrm{m}^{3} / \mathrm{h}$ ou $0,1249 \mathrm{kWh} / \mathrm{m}^{3}$

Na etapa do Diagnóstico Energético realizado antes da implantação do projeto com a operação dos Compressores foram obtidos os seguintes parâmetros:

- Potência média = 470 kW

- Vazão média $=2.786 \mathrm{~m}^{3} / \mathrm{h}$

- Demanda máxima do Sistema de Compressores = 538 kW

Durante o período de implantação do projeto partiu-se com uma nova linha de produção que fez o consumo de ar subir em (3692/2786) = 32,5\%

$\underline{\text { Rendimento do Período anterior à implantação das medidas }}$

Consumo específico $=$ Potência Média $/$ Vazão Média

Consumo específico $=470 \mathrm{~kW} / 2.786 \mathrm{~m}^{3} / \mathrm{h}=0,1687 \mathrm{~kW} / \mathrm{m}^{3} / \mathrm{h}$

Na etapa do Diagnóstico Energético a vazão média foi de $2.786 \mathrm{~m}^{3} / \mathrm{h}$ e na etapa de aferição a vazão média levantada foi de 3.692 m³/h, correspondendo 
a um aumento de $32,5 \%$ na vazão produzida pelo Sistema de Geração de $\mathrm{Ar}$ Comprimido. Este aumento se deu em virtude de que durante a realização do projeto, uma nova linha de produção foi acrescentada ao processo produtivo da fábrica.

Deste modo o cálculo das economias (redução de Demanda e Consumo) levará em consideração este aumento de vazão através da correção da Demanda e Consumo levantados no Diagnóstico Energético, conforme detalhado a seguir:

Para o cálculo do consumo é considerada a Potência Média:

Consumo médio mensal Corrigido $=(623 \mathrm{~kW} \times 730 \mathrm{~h} / \mathrm{mês}) / 1.000 \mathrm{~kW} / \mathrm{MW}=$ $455 \mathrm{MWh} / \mathrm{mês}$

Consumo médio anual Corrigido $=(455 \mathrm{MWh} / \mathrm{mês} \times 12$ meses $/$ ano $)=5.546$ MWh/ano

A Tabela 6.4 apresenta os valores levantados no Diagnóstico Energético e os valores corrigidos para a situação inicial considerando a vazão atual.

Tabela 6.4 - Valores Levantados no Diagnóstico Energético

\begin{tabular}{|c|c|c|}
\hline $\begin{array}{c}\text { Projeção } \\
\text { Diagnóstico x Aferição }\end{array}$ & $\begin{array}{c}\text { Dados do Diagnóstico } \\
\text { Energético } \\
\text { (vazão de } 2.768 \mathrm{~m}^{3} / \mathrm{h} \text { ) }\end{array}$ & $\begin{array}{c}\text { Valores Projetados para } \\
\text { a Vazão pós projeto } \\
\left(3.692 \mathrm{~m}^{3} / \mathrm{h}\right)\end{array}$ \\
\hline Vazão Média & $2.786 \mathrm{~m}^{3} / \mathrm{h}$ & $3.692 \mathrm{~m}^{3} / \mathrm{h}$ \\
\hline Potência Média & 470 kW & 623 kW \\
\hline Potência Máxima & 538 kW & 713 kW \\
\hline Consumo específico & $0,1687 \mathrm{~kW} / \mathrm{m}^{3} / \mathrm{h}$ & $0,1249 \mathrm{~kW} / \mathrm{m}^{3} / \mathrm{h}$ \\
\hline Consumo Mensal & $343 \mathrm{MWh}$ & $455 \mathrm{MWh}$ \\
\hline Consumo Anual & 4.117 MWh & $5.456 \mathrm{MWh}$ \\
\hline
\end{tabular}

Fonte: Elaboração própria com base nos valores do diagnóstico e valores projetados 
Com a correção considerando o aumento de vazão, os dados referentes à situação antes da implantação das medidas de eficientização são:

- Vazão média $=3.692 \mathrm{~m} 3 / \mathrm{h}$

- Potência média = 623 kW

- Demanda máxima do Sistema de Compressores = 713 kW

- Consumo Mensal = $455 \mathrm{MWh}$

- Consumo Anual $=5.456 \mathrm{MWh}$

O cálculo das economias foi realizado considerando-se as diferenças entre os valores de consumo e demanda atuais e os da etapa do diagnóstico projetados para a vazão atual, demonstrado na Tabela 6.5.

Tabela 6.5 - Cálculo das Economias Obtidas na Indústria Estudada

\begin{tabular}{lccc}
\hline Economias Obtidas & $\begin{array}{c}\text { Antes da } \\
\text { Implantação das } \\
\text { Medidas de } \\
\text { Eficientização } \\
\text { (Diagnóstico } \\
\text { Energético } \\
\text { Corrigido) }\end{array}$ & $\begin{array}{c}\text { Após Implantação } \\
\text { das Medidas de } \\
\text { Eficientização } \\
\text { (Etapa de Aferição) }\end{array}$ & Diferença Obtida \\
& $0,1687 \mathrm{~kW} / \mathrm{m}^{3} \mathrm{~h}$ & $0,1249 \mathrm{~kW} / \mathrm{m}^{3} \mathrm{~h}$ & $0,0438 \mathrm{~kW} / \mathrm{m}^{3} \mathrm{~h}$ \\
\hline Rendimento & $713 \mathrm{~kW}$ & $563 \mathrm{~kW}$ & $150 \mathrm{~kW}$ \\
Demanda & $455 \mathrm{MWh}$ & $337 \mathrm{MWh}$ & $117 \mathrm{MWh}$ \\
Consumo Mensal & $5.456 \mathrm{MWh}$ & $4.038 \mathrm{MWh}$ & $1.418 \mathrm{MWh}$ \\
Consumo Anual & & & \\
\hline
\end{tabular}

Fonte: Elaboração própria com base nos valores do diagnóstico e valores projetados

\section{Análise dos Resultados}

Consumo Específico

- Inicial $=0,1687 \mathrm{~kW} / \mathrm{m}^{3} / \mathrm{h}$

- Final $=0,1249 \mathrm{~kW} / \mathrm{m}^{3} / \mathrm{h}$ 


\section{$\underline{\text { Consumo Total }}$}

- Inicial = 455 MWh/mês ou 5.456 MWh/ano

- Final = 337 MWh/mês ou 4.038 MWh/ano

- Economia = 117 MWh/mês ou 1.418 MWh/ano.

O índice específico e o consumo previsto apresentaram uma redução de $26 \%$ em relação à situação inicial.

\section{Demanda}

$$
\begin{aligned}
& - \text { Inicial }=713 \mathrm{~kW} \\
& - \text { Final }=563 \mathrm{~kW} \\
& - \text { Economia }=150 \mathrm{~kW}
\end{aligned}
$$

A redução de demanda foi de 150 kW correspondendo a uma redução de $21 \%$ em relação à demanda inicial projetada.

A tabela 6.6 apresenta a comparação entre as economias previstas no Diagnóstico Energético e as economias reais levantadas nesta etapa de aferição:

\section{Tabela 6.6 - Economias Previstas e Obtidas na Indústria Estudada}

\begin{tabular}{lcc}
\hline & ECONOMIAS & \\
\hline & Diagnóstico Energético & Resultado Real \\
Demanda & $84,57 \mathrm{~kW}$ & $150 \mathrm{~kW}$ \\
Consumo mensal & $100 \mathrm{MWh} / \mathrm{mês}$ & $117 \mathrm{MWh} / \mathrm{mês}$ \\
Consumo anual & $1.205 \mathrm{MWh} / \mathrm{ano}$ & $1.418 \mathrm{MWh} /$ ano \\
Pay back & $22 \mathrm{meses}$ & 18 meses \\
\hline
\end{tabular}

Fonte: Elaboração própria utilizando os dados da medição 


\subsection{Resultados obtidos em 2005 através das ações de eficiência energética e redução de gastos $(R \$ / k W h)$}

O monitoramento dos gastos e do consumo de energia por tonelada produzida passou a partir de junho de 2005 a ser monitorado mensalmente.

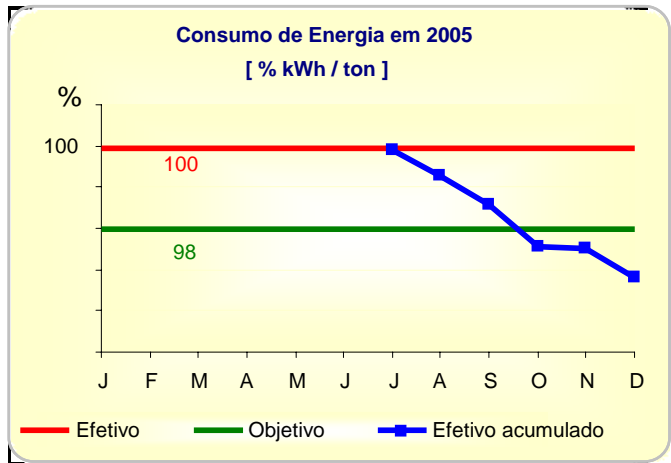

Economia obtida por Eficiência Energética

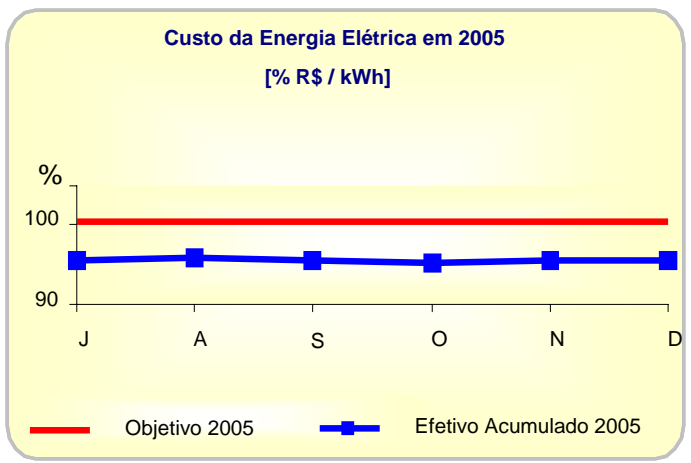

Economia obtida por Negociação Tarifária

\section{Figura 6.18 - Gerenciamento de Energia na Indústria Estudada}

Fonte: Elaboração a partir dos dados da medição

Na Figura 6.18, são apresentados dois indicadores de gestão estabelecidos para a redução dos gastos com as faturas de energia elétrica, nas cinqüenta e quatro unidades consumidoras.

A esquerda a redução efetiva é verificada no consumo de energia elétrica e esta relacionada à implantação dos projetos de eficiência energética nos processos produtivos, a direita a economia efetiva em Reais, relativa ao valor pago pelo kWh consumido, este por renegociação dos contratos, ambos indicadores atingiram em dezembro um valor acima do objetivo estabelecido.

Nota-se que o indicador que referencia a redução de consumo de energia por kWh, projetos e ações buscando a eficiência energética, é dinâmico, pois para cada novo projeto implantado nas unidades produtivas, este indicador é afetado. O interessante é que, como a empresa estimula estes tipos de ações, buscando sempre o respeito por seu cliente, cria-se um espírito de competição 
entre as unidades produtivas, que a cada instante buscam e implantam novos projetos com ações de redução de consumo.

Desta forma a unidade produtiva, a fábrica, torna-se autônoma e competente suficiente para fazer a gestão dos seus consumos de energia $e$ automaticamente apresentar e implantar os projetos pertinentes à redução de consumo.

Entretanto o indicador de custo da energia, este permanece centralizado no corporativo, que pode, a cada ano renegociar e buscar sempre a energia com menor custo, no gráfico o preço foi mantido sem variação, porém em um patamar de $5 \%$ abaixo do objetivo, pois os contratos haviam sido negociados antes de junho daquele ano.

Desta forma obteve-se, naquele ano, uma redução dos gastos com faturas de energia elétrica de $10 \%$ do valor previsto em budget orçamentário.

Para uma indústria não energointensiva, como o caso de estudo, a economia obtida de 10\%, não é significativa em relação ao negócio, pois representaria algo em torno de $0,25 \%$ do custo produtivo total do mesmo período.

O valor em porcentagem não é expressivo, porém o montante envolvido pode representar quantias na casa de milhões de reais. Entretanto, existem fatores importantes por trás de destas ações, como a responsabilidade social, o respeito ao seu consumidor, as boas práticas ambientais, afetados diretamente.

Estes fatores reforçam o conceito de eficiência produtiva ao seu consumidor e estabelece uma cultura interna aos seus colaboradores fortalecendo o conceito da produção eficiente, que é um marco da empresa caso de estudo. 


\section{CAPÍTULO 7}

\section{CONSIDERAÇÕES FINAIS}

O impacto do racionamento levou o empresariado brasileiro a adotar medidas de gestão dos gastos com energia elétrica, bem como programas de uso eficiente.

O estudo de caso apresentado demonstrou que, partindo-se de uma avaliação de disponibilidade de energia elétrica futura, em função de um acontecimento pontual, o racionamento ocorrido em 2001, descobriu-se uma série de oportunidades que impactaram positivamente nos resultados do negócio.

As significativas mudanças ocorridas no setor de energia elétrica permitiram e permitem que o consumidor deixe de ser mero pagador de faturas e passe efetivamente a gerir seus gastos e seu consumo de energia elétrica, principalmente na categoria industrial, possibilitando a este consumidor optar por ter seu fornecedor de energia elétrica no ambiente regulado ou livre, com preços e prazos negociados entre as partes.

Os fatores citados foram os maiores responsáveis pelas ações positivas apresentadas no estudo de caso, contribuindo de forma expressiva no resultado econômico desta empresa em 2005, que desde então incorporou as ações de gestão e de eficiência energética como parte de seu negócio. 
Os resultados apresentados neste estudo, por si só, são suficientes para motivar a perenidade das ações implantadas. Sua continuidade promoverá cada vez mais um avance competitivo, pois, muito embora em grandes empresas, não energointensivas, a energia elétrica represente valores entre $0,5 \%$ a $3 \%$ do custo final do produto, este pode ser o diferencial.

A expressiva redução do gasto com faturas de energia elétrica, ocorrida naquele ano na empresa estudo de caso, através das ações de gestão implantadas, foi motivo para que o grupo de colaboradores participantes do projeto ganhasse o terceiro lugar do prêmio interno excelência naquele ano.

O aprendizado, as oportunidades identificadas e os conceitos absorvidos foram transformados em ações reais e efetivas que fizeram e fazem à diferença, pois além da economia financeira, garante a sustentabilidade, o respeito ao consumidor, reforça a imagem da empresa no mercado e dissemina a cultura de eficiência produtiva ao corpo de trabalhadores.

Este trabalho apresentou uma metodologia para reduzir os valores pagos nas faturas de energia elétrica, com as ações de: (i) avaliar os itens componentes do consumo; (ii) analisar a melhor alternativa de contratação de energia no ambiente cativo ou livre; (iii) Introduzir novas tecnologias que se mostrem mais eficientes no processo produtivo, e (iv) gerenciar indicadores de desempenho.

Sugere-se para continuidade deste trabalho a verificação do comportamento da indústria estudada nos últimos quatro anos quanto à implantação de ações de gestão e de eficiência, avaliando os resultados que foram obtidos a partir de 2005.

Interessante também seria um estudo complementar sobre às opções de compra de energia visto que, como apresentado neste trabalho, os riscos de contratação permeiam os dois ambientes, o livre e o regulado. Para tanto, deverá ser feita uma análise da oferta de energia no mercado, pois os preços oscilam nos dois ambientes dependendo do montante de energia disponível. 


\section{REFERÊNCIAS BIBLIOGRÁFICAS}

ABRACEEL - Associação Brasileira dos Agentes Comercializadores de Energia Elétrica, 2006. Disponível no site http://www.abraceel.com.br consulta em 25.06.2009.

AMARAL FILHO, J.B.A. A Reforma do Setor Elétrico Brasileiro e a Questão da Modicidade Tarifária. Tese (Doutorado) - UNICAMP, 2007.

AGUIAR, O.S. O Mercado Brasileiro de Energia Elétrica: Critérios de Decisão na Migração de Consumidores para o Ambiente de Contratação Livre. Dissertação (Mestrado). Universidade Federal de Pernambuco. Recife. 2008.

ANEEL - AGÊNCIA NACIONAL DE ENERGIA ELÉTRICA - Resolução 456 de 29 de novembro de 2000. Estabelece, de forma atualizada e consolidada, as Condições Gerais de Fornecimento de Energia Elétrica. Referência disponível na Internet. http://www.aneel.gov.br. consulta em 25.06.2009.

(2005) Cadernos Temáticos ANEEL - Tarifas de Fornecimento de Energia Elétrica, 2005. Referência disponível no site http://www.aneel.gov.br. consulta em 25.06.2009.

(2008) Comercialização de energia elétrica proveniente de UTE a biomassa Superintendência de Estudos do Mercado - SEM /Aneel - São 
Paulo, 02 de abril de 2008. Referência disponível no site http://www.aneel.gov.br. consulta em 26.06.2009.

BARBOSA, P.S.F. Porque os Serviços de Energia Elétrica estão Subindo? Valor Econômico, São Paulo, 25 de setembro de 2007. Opinião. Referência disponível no site http://www,valoronline.com.br. consulta em 26.06.2009

BEN - Balanço Energético Nacional, 2008. Disponível no site http://www.mme.gov.br consulta em 26.06.2009

BRASIL, (1934) Decreto 24.643, de 10 de julho de 1934 - Decreta o Código de Águas. Presidência da República, 1934.

(1960) Lei 3.782, de 22 de julho de 1960. Cria os Ministérios da Indústria e do Comércio e das Minas e Energia e dá outras providências. Presidência da República, 1960.

(1961) Lei 3.890, de 25 de abril de 1961. C Autoriza a União a constituir Centrais Elétricas Brasileiras SIA - Eletrobrás e dá outras providências. Presidência da República, 1961

(1971) Lei 5.655, de 20 de maio de 1971. Dispõe sobre a remuneração legal do investimento dos concessionários de serviços públicos de energia elétrica, e dá outras providências. Presidência da República, 1971.

(1974) Decreto Lei $1.383 / 74$, de 26 de dezembro de 1974. Altera a redação do artigo 4 da lei 5655, e dá outras providências. Presidência da República, 1974.

(1977) Decreto Lei 79706, de 18 de maio de 1977. Dispõe sobre os atos da administração pública relativamente ao controle de preços. Presidência da República, 1977. 
(1988) Constituição da República Federativa do Brasil, de 05 de outubro de 1988.

(1990) Decreto $n^{\circ} .99 .656$, de 26 de outubro de 1990. Dispõe sobre a criação, nos órgãos e entidades da Administração Federal direta e indireta, da Comissão Interna de Conservação de Energia (CICE), nos casos que menciona, e dá outras providências. Presidência da República, 1990.

(1993) Decreto 915, de 06 de setembro de 1993. Autoriza a formação de consórcios para geração de energia elétrica. Presidência da República, 1993.

(1993a) Decreto 1.009, de 22 de dezembro de 1993. Cria o Sistema Nacional de Transmissão de Energia Elétrica SINTREL, e dá outras providências. Presidência da República, 1993.

(1995) Lei 8.987, de 13 de fevereiro de 1995. Dispõe sobre o regime de concessão e permissão da prestação de serviços públicos previsto no Art. 175 da Constituição Federal, e dá outras providências. Presidência da República, 1993.

(1995a) Lei 9.074, de 7 de julho de 1995. Estabelece normas para outorga e prorrogações das concessões e permissões de serviços públicos e dá outras providências. Presidência da República, 1975.

(1996) Decreto 2003 de 10 de setembro de 1996. Regulamenta a produção de energia elétrica por Produtor Independente e por Autoprodutor e dá outras providências. Presidência da República, 1996.

(1996) Lei 9.427, de 26 de dezembro de 1996. Institui a Agência Nacional de Energia Elétrica - ANEEL, disciplina o regime das concessões 
de serviços públicos de energia elétrica e dá outras providências. Presidência da República, 1996.

(1998) Decreto 2.655, de 2 de julho de 1998. Regulamenta o Mercado Atacadista de Energia Elétrica, define as regras de organização do Operador Nacional do Sistema Elétrico, de que trata a Lei $n^{\circ} .9 .648$, de 27 de maio de 1998, e dá outras providências. Presidência da República, 1998.

(2001) Lei 10.295 , de 17 de outubro de 2001. Dispõe sobre a Política Nacional de Conservação e Uso Racional de Energia e dá outras providências. Presidência da República, 2001.

(2002) Lei 10.438, de 26 de abril de 2002. Dispõe sobre a expansão da oferta de energia elétrica emergencial, recomposição tarifária extraordinária, cria o Programa de Incentivo às Fontes Alternativas de Energia Elétrica (PROINFA), a Conta de Desenvolvimento Energético (CDE), dispõe sobre a universalização do serviço público de energia elétrica, dá nova redação às Leis $n^{\circ}$. 9.427, de 26 de dezembro de 1996, $n^{\circ}$. 9.648, de 27 de maio de 1998, $n^{\circ}$. 3.890-A, de 25 de abril de 1961, $n^{\circ}$. 5.655, de 20 de maio de 1971, $n^{\circ}$. 5.899, de 5 de julho de 1973, $n^{\circ}$. 9.991, de 24 de julho de 2000, e dá outras providências. Presidência da República, 2002.

(2002a) Lei 10.433, de 25 de abril de 2002. Dispõe sobre a autorização para a criação do Mercado Atacadista de Energia Elétrica MAE, pessoa jurídica de direito privado, e dá outras providências. (Revogada pelo art. 29 da Lei 10.488, de 15/03/2004). Presidência da República, 2002.

(2004) Lei 10.847, de 15 de março de 2004. Autoriza a criação da Empresa de Pesquisa Energética - EPE e dá outras providências. Presidência da República, 2004. 
(2004a) Decreto $n^{\circ}$. 5.177, de 12 de agosto de 2004. Regulamenta os arts. $4^{\circ}$ e $5^{\circ}$ da Lei $n^{\circ} .10 .848$ de 15 de março de 2004 , e dispõe sobre a organização, as atribuições e o funcionamento da Câmara de Comercialização de Energia Elétrica - CCEE. Presidência da República, 2004.

(2004b) Lei $n^{\circ}$. 10.848, de 15 de março de 2004. Dispõe sobre a comercialização de energia elétrica, altera as Leis $n^{\circ}$ s 5.655, de 20 de maio de 1971, 8.631, de 4 de março de 1993, 9.074, de 7 de julho de 1995, 9.427, de 26 de dezembro de 1996, 9.478, de 6 de agosto de 1997, 9.648, de 27 de maio de 1998, 9.991, de 24 de julho de 2000, 10.438, de 26 de abril de 2002, e dá outras providências. Presidência da República, 2004.

Barros Paulo B. (2006) Panorama do setor elétrico no Brasil, Rio de Janeiro, Centro de Memória da Eletricidade do Brasil, 2006.

CAMARGO, L.G.B.C (2005) O Setor Elétrico Brasileiro e Sua Normatização Contemporânea. Universidade Católica de Santos. Bacharelado em Direito. Santos, 2005.

CCEE (2006) Câmara de Comercialização de Energia Elétrica. Evolução do Número de Clientes Livres. Referência disponível no site http://www.ccee.org.br. consulta em 26.06.2009

CPFL (2009) Companhia Paulista de Força e Luz. Tarifas Azul e Verde. Disponível no site http://www.cpfl.com.br. consulta em 26.06.2009

DIEESE (2007) Departamento Intersindical de Estatística e Estudos Socioeconômicos. As Tarifas de Energia No Brasil: Sistemática de correção e Evolução dos Valores. Nota Técnica nº 58. Dezembro de 2007.

ELETROBRÁS - Centrais Elétricas Brasileiras. Revisão Institucional do Setor Elétrico - REVISE, 1988, apud RAMALHO, E.L. Abrangência e Eficácia da Descentralização das Atividades de Regulação e Fiscalização 
no Setor de Energia Elétrica - Estudo de Caso CSPE. Tese (Doutorado) UNICAMP, 2003.

ENERGIA BRASIL Oferta de Energia. Referência disponível no site http://energiabrasil.gov.br. consulta em 26.06.2009

ENERGIA BRASIL Relatório de Progresso n. 4. Referência disponível no site http://energiabrasil.gov.br. consulta em 26.06.2009

FERREIRA, K.L. Privatização do Setor Elétrico no Brasil. In: A Privatização no Brasil - O Caso dos Serviços de Utilidade Pública. BNDES, 2000. Referência disponível no site http://www.bndes.gov.br. consulta em 26.06.2009

GARCIA, A.G. Impacto da Lei de Eficiência Energética para Motores Elétricos no Potencial de Conservação de Energia na Indústria. Dissertação (Mestrado). Universidade Federal do Rio de Janeiro. RJ-Brasil, dezembro de 2003.

GCE - CÂMARA DE GESTÃO DA CRISE DE ENERGIA ELÉtRICA, Resolução 01, de 16 de maio de 2001. Referência disponível no site http://www.aneel.gov.br/cedoc. consulta em 26.06.2009

GOLDENBERG, J., PRADO, L.T.S. (2003) Reforma e crise do setor elétrico no período FHC. Tempo Social. Vol. 15 nº. 2, São Paulo, Nov. 2003

GREINER, P. Bases para um Modelo Auto-regulador para o Setor Elétrico Brasileiro. Tese (Doutorado) - FGV/EAESP, 1994.

JANNUZZI, G. M. . Políticas Públicas para Eficiência Energética e Energia Renovável no Novo Contexto de Mercado. 1. ed. Campinas: Editora Autores Associados, 2000. v. 1

KELMAN, J. Risco Regulatório. Publicado no jornal "O Estado de São Paulo", edição de 19.07.2006. 
LEITE, A. A Energia do Brasil. Editora Nova Fronteira, 1997.

LEMGRUBER, E.F., et al. (org). Gestão de Risco e Derivativo: aplicações no Brasil. São Paulo: Atlas, 2001 apud AGUIAR, O.S. (2008) O Mercado Brasileiro de Energia Elétrica: Critérios de Decisão na Migração de Consumidores para o Ambiente de Contratação Livre. Dissertação (Mestrado). Universidade Federal de Pernambuco. Recife. 2008.

LESSA, C. A Estratégia de Desenvolvimento 1974-1986: Sonho e

Fracasso, ed. UNICAMP - Instituto de Economia, $2^{\mathrm{a}}$ ed., Campinas, 1998.

LIMA, R.G. Comercialização de Energia - alguns conceitos e princípios. Artigo Técnico. Rio de Janeiro, 2006, apud AGUIAR, O.S. (2008) 0 Mercado Brasileiro de Energia Elétrica: Critérios de Decisão na Migração de Consumidores para o Ambiente de Contratação Livre. Dissertação (Mestrado). Universidade Federal de Pernambuco. Recife. 2008.

MARTINS, M.P.S. Inovação Tecnológica e Eficiência Energética. Monografia (MBA em Energia Elétrica). Universidade Federal do Rio de Janeiro. RJ-Brasil, outubro de 1999.

MEDEIROS, R.A. O Capital Privado na Reestruturação do Setor Elétrico Brasileiro. In: História e Energia 6. Eletropaulo - Departamento de Patrimônio Histórico, São Paulo, 1996.

MME - MINISTÉRIO DE MINAS E ENERGIA (2001) COMISSÃO DE ANÁLISE DO SISTEMA HIDROTÉRMICO DE ENERGIA ELÉTRICA (2002) 0 desequilíbrio entre oferta e demanda de energia elétrica. (Contribuição Voluntária de Sergio Valdir Bajay - Membro da Comissão - Gestão do Setor Elétrico Através de Políticas Públicas, Planejamento e Regulação). Anexo K do Relatório, 2002.

OLIVEIRA, R.M. Gerenciamento de Energia Elétrica em Uma Empresa de Saneamento Ambiental. VI Simpósio Ítalo Brasileiro de Engenharia Sanitária e Ambiental. Vitória-ES, 01 a 05 de outubro de 2002. 
OLIVEIRA, L.S. Gestão do Consumo de Energia Elétrica no Campus da UnB. Dissertação (Mestrado). Universidade de Brasília. Faculdade de Tecnologia. Departamento de Engenharia Elétrica. Brasília - DF, agosto de 2006.

POOLE, A.D., GELLER, H. O Novo Mercado de Eficiência Energética no Brasil. Abril, 1997. Referência disponível no site http://www.inee.org.br/down_loads/escos/escomerc.pdf consulta em 27.06.2009

PIRES, J.C.L. et al. As Perspectivas do Setor Elétrico após o Racionamento. In: Revista do BNDES, Volume $9-\mathrm{n}^{\circ}$. 18, Dezembro, 2002.

PORRUA, F. Metodologia para Precificação e Análise de Risco de Contratação entre Submercados no Setor Elétrico Brasileiro. Dissertação (mestrado). Universidade Federal do Rio Grande do Sul. Porto Alegre, 31 de março de 2005.

PUC - RIO, Teses Abertas. Referência disponível no site http://www2.dbd.puc-rio.br/pergamum/tesesabertas/0521405_07_cape_01.pdf em 07.10.2009

PURE, Programa para o uso eficiente de energia. Referência disponível no site - http://www.usp.br/pure consulta em 21.09.2009

RAMALHO, E.L. Uma Visão da Comercialização de Energia Elétrica, pelas indústrias de Açúcar e Álcool, diante da Reestruturação do Setor Elétrico Nacional. Dissertação (Mestrado) - UNICAMP, 1999.

RAMALHO, E.L. Abrangência e Eficácia da Descentralização das Atividades de Regulação e Fiscalização no Setor de Energia Elétrica Estudo de Caso CSPE. Tese (Doutorado) - UNICAMP, 2003. 
SAUER, I. (2002) Energia Elétrica no Brasil Contemporâneo - A Reestruturação do Setor, Questões e Alternativas. In: Política Energética e Crise de Desenvolvimento: A Antevisão de Catulo Branco. Org. Adriano Murgel Branco. São Paulo, Editora Paz e Terra, 2002.

SENAI (2000) Serviço Nacional de Aprendizado Industrial. Série Manuais de Produção Limpa, Senai-RS - Avaliação Energética - Centro Nacional de Tecnologias Limpas SENAI-RS, Porto Alegre, 2003.

SILVA, T.A., BELDERRAIN, M.C.N. Estudo da relação entre Gerenciamento de Risco e Análise de Decisão. ITA, 2002. Referência disponível no site http:// www.bibl.ita.br/xencita/Artigos/55.pdf. consulta em 26.06.2009

SPALDING, E.C. Desafios e Oportunidades do Mercado de Livre Contratação Perspectivas Futuras. 14 de Outubro de 2008 - FIESP

SOLA, A.V.H., KOVALESKI, J.L. Eficiência Energética nas Indústrias: Cenários \& Oportunidades. XXIV Encontro Nacional de Engenharia de Produção. Florianópolis, SC. Brasil, 03 a 05 de nov. de 2004.

WAISMAN, D. A Lobotomização do Dinossauro - Ascensão e Queda do Setor Elétrico Estatal - Um Ensaio Histórico e Político. Março, 1980, apud Uma Visão da Comercialização de Energia Elétrica, pelas indústrias de Açúcar e Álcool, diante da Reestruturação do Setor Elétrico Nacional. Dissertação (Mestrado) - UNICAMP, 1999. 